\title{
THE BOTTOM FAUNA OF THE ENGLISH CHANNEL
}

\author{
By N. A. Holme \\ The Plymouth Laboratory
}

(Text-figs. I-I 5)

The collections described here form a survey of the bottom fauna along the whole length of the south coast of England. Further collections are being made in mid-Channel and near the French coast, and it is hoped to publish the results at a later date. Partly because of the absence of rich fishing grounds, the bottom fauna of the English Channel has been somewhat neglected in the past, and previous information has been mainly confined to the more western areas, in the neighbourhood of the marine stations at Plymouth and Roscoff. Although the fauna of the Channel is quantitatively poor when compared with the fishing grounds of the North Sea, it provides an interesting study of distribution trends since there are considerable variations both in temperature and in other hydrographic conditions between the wide western end, parts of which were dominated by a Sagitta elegans plankton community in the 1920's, and the more land-locked areas of the eastern half, characterized by a Sagitta setosa community. In recent years evidence has accumulated that benthos species may usefully supplement plankton species as a perhaps more permanent record of hydrographic conditions. Thus Blacker (I957) has shown that certain species may be used as indicators of either Arctic or Atlantic water in Arctic regions, the correlation being apparently with temperature, while in the North Sea Ursin (1960) has suggested that factors other than temperature may be responsible for the local distributions shown by some echinoderms. In the English Channel both temperature and certain unexplained hydrographic factors appear to play a part in the distribution of different species, and this paper is an attempt to establish the main trends of distribution in the Channel and to correlate them with the hydrography of the area.

I am indebted to Lt.-Cdr. C. A. Hoodless, R.N.R., and the officers and crew of R.V. 'Sarsia' for their skill and patience in working the anchordredge, sometimes under difficult conditions. Preliminary sorting of the catches on board ship was only made possible by the generous and able assistance of Dr P. R. O. Barnett, my wife, Mrs M. L. Holme, and Messrs G. R. Forster, E. Harada, A. D. Mattacola, D. J. Scarrett and G. M. Spooner. I am also indebted to $\mathrm{Mr}$ E. Ford for allowing me to use his notes on an unpublished grab survey of Great West Bay in 1923, and to Mr L. Birkett for 
information on the fauna of the central North Sea, Mr A. D. McIntyre for information on the Scottish area, and Dr J. A. Allen for the Clyde area.

The following have been of assistance in the identification of certain groups: Dr J. A. Allen (Nucula), Mrs Eve Southward (Arenicola), Mr G. M. Spooner (certain Crustacea), and Dr A. C. Stephen (Maxmulleria).

I would like to thank Dr P. R. O. Barnett, Mr L. Birkett, Mr A. D. McIntyre and Dr A. J. Southward for helpful criticism of the manuscript.

Dr Barnett has taken Vacuum-Grab samples at each station for a survey of the microfauna of the sediments, the results of which he proposes to publish at a later date.

\section{METHODS}

Collections were made from R.V. 'Sarsia', using a modified anchor-dredge (Fig. I), which was slightly larger and much more robust than the original model (Forster, I953). It did not dig as deeply as previous models, and tended to drag for a short distance along the bottom rather than to anchor the ship. It represents a compromise between ordinary dredges, which scarcely dig in at all on sandy grounds, and the original anchor-dredge which digs in

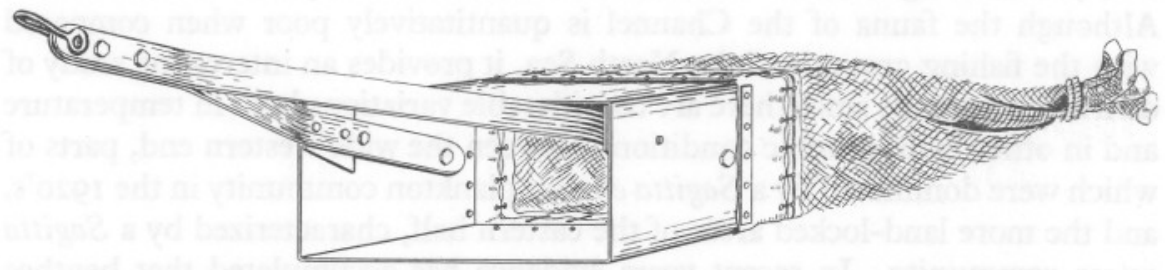

Fig. I. The modified anchor-dredge. The steel frame forming the mouth of the dredge is $2 \mathrm{ft}$. $(6 \mathrm{I} \mathrm{cm})$ wide, $\mathrm{I} \mathrm{ft}(30.5 \mathrm{~cm})$ high, and $\mathrm{I} 6 \mathrm{in}$. $(40.7 \mathrm{~cm})$ deep. Overall length of dredge without net is $4 \mathrm{ft}(122 \mathrm{~cm})$, and weight $c a 70 \mathrm{~kg}$. The wishbone arms are set at an angle of $18^{\circ}$ to the long axis of the frame, and swivel on the hindmost bolts. They can be locked in position by the set screw in front of this bolt. Reinforcing strips attached to the arms prevent it cutting into the edge of the frame. Drawn by Mr G. A. Battin.

very deeply but which may be unsuitable for use from a large vessel owing to the very considerable strain on the warp when it becomes anchored in the deposit. The new model was designed by $\mathrm{Mr}$ Forster to work either way up, the wishbone towing arm swivelling accordingly, but in shallow water it was found to dig more effectively with the arm locked to one side. If lowered right side up while there was some way on the ship, it almost invariably landed on its correct side. In deeper water (over 80-100 m) there may be some difficulty in landing it right way up, and the arm can then be unlocked so that it will dig whichever way it lands.

The new dredge has been worked at over 200 stations on all types of ground, without being damaged, although the net had frequently to be mended or replaced. The net was of No. 2 Courlene of $\frac{1}{2}$ in. (12.7 mm) bar, the lower end being open and tied with a cod-end knot. For work in deeper water a stramin 
lining is recommended, but was not used in this survey as a reasonably large sample of deposit was obtained at most stations. In shallow water and in calm weather washing-out of the sample while the dredge is being hauled is not excessive. Only a single haul was taken at most stations. Positions were obtained by Decca Navigator, and depths, from the echo-sounder, were corrected for tidal height based on the nearest port for which tidal data are available.

Treatment of the samples aimed at providing the fullest qualitative evaluation of the fauna. Samples of deposit were often very large (I00 1. or more), so that it was not always possible to sieve the whole sample. Where the deposit was sufficiently fine it was passed through a sieve with square openings $2.2 \mathrm{~mm}$ across, failing this sieves of $5 \mathrm{~mm}$ or I $.5 \mathrm{~mm}$ were employed. Often only a portion was sieved, and the remainder was then hosed down on deck, conspicuous animals and dead shells being picked out.

Although there are considerable variations in the samples at each station, due both to the volume of deposit brought up, and to its subsequent treatment on deck, the numbers of individuals of each species have been noted as a rough guide to their density on the bottom.

Dead shells were also recorded, on a semi-quantitative basis, and such records are of value in confirming the 'absence' of certain species in particular areas.

\section{VALIDITY OF THE SAMPLES}

The anchor-dredge rather than the grab was used in this survey for two reasons: first because it was at first believed that much of the area was rocky or stony and therefore unsuitable for the grab, and secondly because the density of species is in general low in the Channel, necessitating large samples for adequate qualitative sampling. The samples correspond roughly to $\frac{1}{2}-\mathrm{I} \mathrm{m}^{2}$ excavated to a depth of $15 \mathrm{~cm}$, but considerable variations in area and depth sampled clearly exist. The samples appear to be adequate for collecting representative members of the burrowing fauna at each station, but are insufficient for obtaining larger members, mainly of the epifauna, which are known, from trawl catches, to occur on the grounds.

This paper is concerned with the main trends of distribution in the Channel, and for this purpose it was desirable to sample a range of sediment grades in each area, and also to sample at a variety of depths. This ideal could not be fully realised as no two sediments are identical, and in certain areas sediments of a particular grade were absent. Thus coarse deposits are poorly represented in the western half of Great West Bay, and fine deposits are lacking in the tide-scoured area south of the Isle of Wight.

By definition, sampling cannot establish the absence of a species from a particular area. Where the density of a species is very low, it may cease to form a breeding population, and so rank as an 'exotic' perhaps transported in the larval stage from a denser, breeding population elsewhere. Thus we may 
be justified in considering a species normally sufficiently dense to occur in the dredge samples to be absent, for practical purposes, when it is not taken in a series of dredge-hauls on apparently suitable deposits.

\section{CONDITIONS IN THE CHANNEL}

Some of the hydrographic and geological features of the Channel have been summarized by Crisp \& Southward (1958), and additional information on water movements in the mouth of the Channel is given by Cooper (1960a,b). In general, the floor of the Channel slopes gently both along and across its main east-west axis. In the western entrance depths of about $110 \mathrm{~m}$ occur in mid-channel, decreasing progressively to a maximum of $50 \mathrm{~m}$ in midchannel in the Straits of Dover. From mid-channel shorewards depths decrease to about $35 \mathrm{~m}$ close to the south Cornish and Devon coasts, west of Start Point, sloping more abruptly up to the beach. Consequently the area inside say $20 \mathrm{~m}$ is small in extent and often too close to the shore to be sampled. Across Great West Bay and farther east, however, the $35 \mathrm{~m}$ contour often lies io or more miles from shore. In selecting stations for this survey an attempt was made to sample a range between 10 and $50 \mathrm{~m}$ depth in each area. Consequently stations off the Cornish coast lie mainly within a mile or two of the shore, while farther east they are more widely scattered, usually at a greater distance from the coast.

It is now known (King, 1954) that in many parts of the Channel there is only a thin veneer of sediment overlying the rock formations. A I m coring tube obtained rock samples from most parts of the Channel, except Great West Bay, and off Plymouth the depth of sediment is only I5-30 cm (Holme, 1953), less in places, with rocky outcrops in some areas. Sediment depths less than about $15 \mathrm{~cm}$ would restrict the occurrence of deeper-burrowing species, particularly species like Lutraria and Upogebia. In most areas, however, a representative burrowing fauna has been taken, indicating perhaps the occurrence of deeper pockets of sediment on grounds where the average depth of sediment is small.

Except possibly in late summer, there is a residual flow of water from west to east up the Channel and into the North Sea. Practically all the water in the Channel (apart from that provided by precipitation) is therefore derived from various water masses lying in different areas and depths off the mouth of the Channel. In passing up-Channel changes in the properties of these waters occur, the most apparent being that of temperature. At the mouth of the Channel surface temperatures fluctuate from about $10^{\circ} \mathrm{C}$ in February to $16^{\circ} \mathrm{C}$ in August (Lumby, 1935), while in the Straits of Dover the range is from $6 \frac{1}{2}^{\circ}$ to $16^{\circ} \mathrm{C}$.

In mid-channel a tongue of east-going water, travelling more rapidly than in coastal areas where eddying may occur, carries the thermal properties of 
waters in the western Channel right up through the Straits of Dover. Thus in August the mid-channel water off Dungeness is about $\frac{3}{4}^{\circ} \mathrm{C}$ cooler than inshore, while in February it is $\frac{3}{4}{ }^{\circ} \mathrm{C}$ warmer.

Data on bottom temperatures are less complete, but the main features are shown in Fig. 2. In winter, complete vertical mixing occurs, so that the surface and bottom temperatures for February are identical. In summer a thermocline is set up in the western half of the Channel, but in the east, because of stronger tidal streams and shallower water, the vertical temperature gradient is small (Matthews, I9I I ; Dietrich, I950). It follows that there
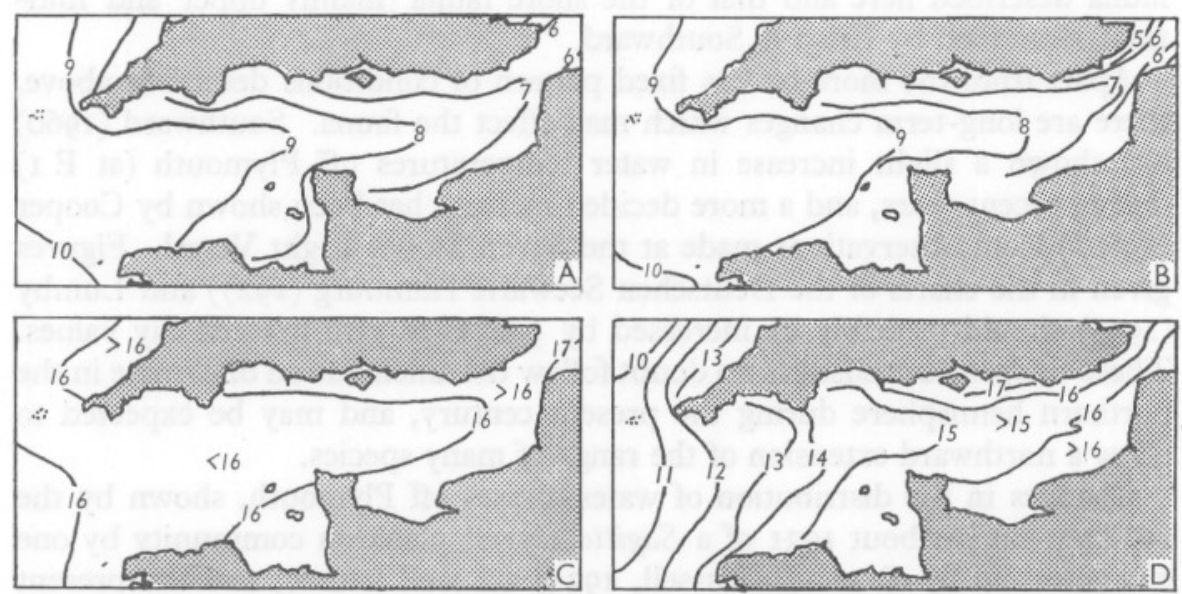

Fig. 2. Isotherms $\left({ }^{\circ} \mathrm{C}\right)$ at surface and bottom for February (A, B) and August (C, D). From Deutschen Seewarte Hamburg (1927).

is a considerable east-west temperature gradient on the bottom in summer, whereas on the surface temperature variations are little more than a degree. Close inshore the existence of eddies and counter-currents may cause local variations in temperature not revealed on the charts, and it seems possible that thermoclines may become temporarily established inshore in the eastern Channel in warm weather.

Surface salinity shows a slight decrease up-Channel (Lumby, I935). Patches of lower salinity occur near the mouths of rivers, but, apart from these, salinities are not appreciably below $34 \%$ anywhere in the Channel in February. Salinity therefore appears unlikely to be a factor controlling distribution in open Channel waters.

Exposure to Atlantic swell from the west naturally decreases up-Channel, but the shallower water and increased tidal currents east of Portland probably produce a more disturbed bottom in these areas. These effects not only prevent a thermocline from becoming established but also hinder the settlement of silt and clay, which remain in suspension, so making the water more 
turbid. There is a progressive increase in turbidity eastward up-Channel, probably accelerated on passing into the eastern basin. Large quantities of silt in suspension may affect the filtering rates and growth of certain lamellibranchs (p. 434) and this factor may prove critical for certain species.

Other factors which change from west to east are summarized by Crisp \& Southward (I958), but for the offshore bottom fauna the temperature régime differs from that experienced by the shore fauna, notably in the absence of subzero temperatures and frosts. For this, and for other reasons, too close a comparison should not be drawn between the distribution of the offshore fauna described here and that of the shore fauna (mainly upper and midtidal) described by Crisp \& Southward.

Apart from the more-or-less fixed pattern of conditions described above, there are long-term changes which may affect the fauna. Southward (I960) has shown a slight increase in water temperatures off Plymouth (at E I) during recent years, and a more decided increase has been shown by Cooper $(1960 b)$ from observations made at the Seven Stones Light Vessel. Figures given in the charts of the Deutschen Seewarte Hamburg (1927) and Lumby (1935) should probably be increased by $\frac{1}{2}-\mathrm{I}^{\circ} \mathrm{C}$ to give present-day values. These temperature changes no doubt follow the amelioration of climate in the northern hemisphere during the present century, and may be expected to allow a northward extension of the range of many species.

Changes in the distribution of water-masses off Plymouth, shown by the replacement in about I93I of a Sagitta elegans plankton community by one characterized by $S$. setosa (Russell, I935) are well known, and the present position is reviewed by Southward (196I). Earlier grab surveys by $\mathrm{Mr} \mathrm{E}$. Ford off Plymouth and in Great West Bay in 1922-23, made when the $S$. elegans community occurred off Plymouth, are valuable for comparison with the present-day bottom fauna under $S$. setosa conditions.

\section{BOTTOM-DEPOSITS AND FAUNA}

Pratje (1950) gives a chart showing the general disposition of sediments in the Channel. Much of the bed of the Channel is covered by gravels or sands, and deposits composed largely of mud are very localized. In Great West Bay and Rye Bay in particular there is an abundance of fine quartz sand, but elsewhere other materials form a considerable proportion of the deposits. For example, flints and chalk are a feature of the deposits in the more eastern parts of the Channel, while off much of Devon and Cornwall the Devonian slates of the coastline contribute shaly materials to the inshore deposits. These finally break down to silt and clay, and so do not contribute towards the accumulation of sandy deposits. Calcareous materials are present in nearly all deposits (see Allen, 1899, for analyses of calcium carbonate in sediments off Plymouth), and often accumulate to form characteristic shell-gravels formed mainly of 
lamellibranch valves. There are also coralline gravels formed from the remains of the alga Lithothamnion calcareum off the Cornish coast.

In few places in the Channel do high population densities approaching those in the North Sea occur. The fauna at the western end of the Channel is distinguished more by the number of species it contains than for their density, but equally dense total populations, comprising fewer species, occur at the eastern end, particularly in Rye Bay.

Although this survey is restricted to inshore areas (Fig. 3), there is some evidence that these contain the more productive grounds. Collections taken farther offshore have usually proved disappointing, with the exception perhaps of the Eddystone region (depth $c a .65 \mathrm{~m}$ ) which appears to be richer in individuals and species than the inshore grounds off Plymouth.

Apart from the Plymouth and Roscoff neighbourhoods, our knowledge of the Channel fauna is very incomplete. There is no general account of the bottom fauna off the Cornish coast west of Looe, nor of the eastern Channel beyond the Isle of Wight. The fauna of Great West Bay is described by Holme (1950), and that of the Dorset coast by Spooner and Holme (I96I).

\section{Brief description of areas sampled}

Mount's BAy. Much of the bottom on the west side of the Lizard peninsula appears to be rocky, making dredging difficult and unprofitable. Most of the Bay is fully exposed to the south and west, but Penzance Bay is more sheltered and has deposits of gravel and stones, also of muddy sand, supporting a varied fauna. The fauna would probably be rather rich if more sheltered from wave action.

Falmouth Bay and the eastern side of the Lizard are sheltered from the west, and the fauna is relatively rich in numbers of species and of individuals. Deposits are varied, and include Lithothamnion gravels in parts of Falmouth Bay.

St Austell Bay is well sheltered from the west and south-west. Presentday deposits appear to be largely derived from washings from the St Austell china clay workings, and include kaolin, quartz sand, and mica flakes. Lithothamnion gravels also occur, this being the farthest east that they were found in the survey. Isolated pieces of dead Lithothamnion are taken up-Channel, however; on Admiralty charts they are often recorded as 'coral'. Fine muddy sands predominate in the Bay, with a rich and varied burrowing fauna.

Plymouth AREA. Eastward from St Austell Bay the coastline becomes more exposed to the south-west, although such exposure is less than in Mount's Bay. The bottom is patchy with rock, gravel or shale in many places, patches of fine sand occurring in Whitsand and Bigbury Bays. Dense beds of Ophiothrix fragilis occur here and elsewhere along the south Cornish coast. There is a noticeable decline in species and individuals compared with the two previous areas. 


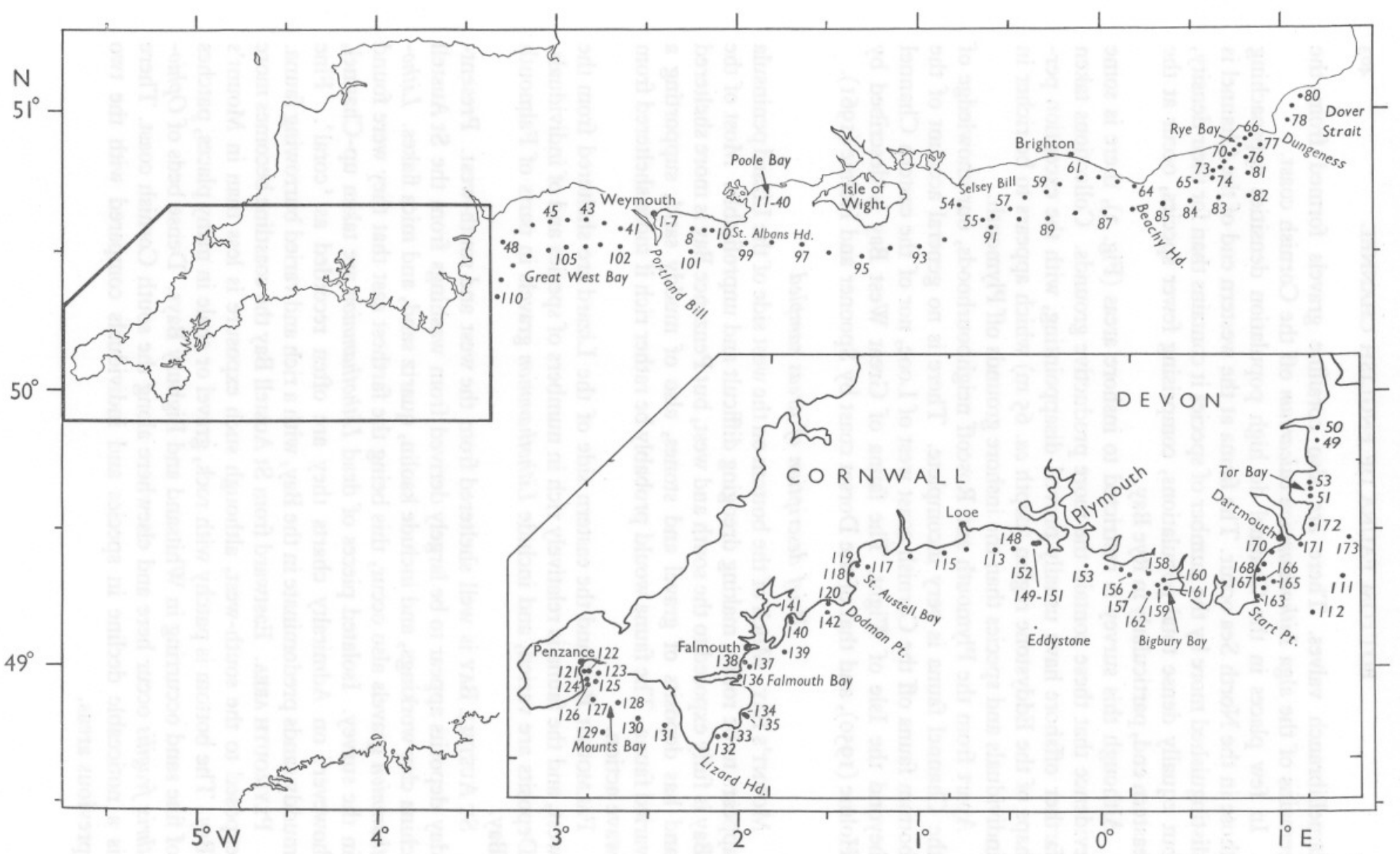

Fig. 3. Chart showing station positions. Where stations lie in sequence along a line, intermediate station numbers are omitted. 
Great West BAy. Apart from deposits of gravel in Start Bay and towards Portland the bottom is of fine sand (derived from Permo-triassic sandstones) mingled with a varying proportion of mud. Both tidal streams and waveaction are much less severe than in the Plymouth area (Kyle, I903), so that muddy deposits are extensive, particularly in and around Tor Bay. Dense beds of certain species occur, among them the Spisula solida bed in Start Bay (now less dense than previously), also beds of Lutraria lutraria, Turritella communis and Callianassa subterranea (Holme, I950).

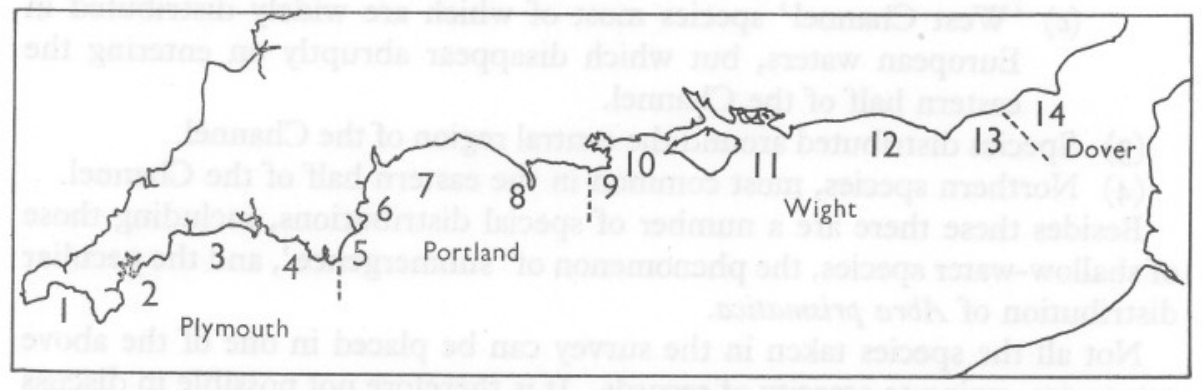

Fig. 4. Chart showing positions of the fourteen areas, each of ten stations, into which the Channel was divided. Meteorological Office sea areas are also shown.

Weymouth Bay. This small bay is well sheltered by Portland Bill and supports quite a rich fauna in mixed deposits of sand, mud, or gravel (Spooner \& Holme, I96I), but farther east, off Lulworth, the bottom is of rock or gravel, exposed to greater disturbance by waves and tides, and the fauna is rather poor.

Poole BAy is relatively sheltered, with deposits of mud, gravel or stones, with clean sand in one part (Spooner \& Holme, I96I). The mud tends to be black and anaerobic, a condition rare in offshore deposits in the Channel. The Bay favours certain species, notably Nucula spp., but certain sand burrowers such as Echinocardium were noticeably absent from the samples. Crepidula fornicata is very common in this area.

ISLE OF WIGHT. South of the Isle of Wight the bottom is 'rough' and swept by strong tidal streams. The dredge brought up mainly stones and lumps of chalk, with a meagre attached fauna.

SElsey Bill to BeAchy HeAd. The bottom is rather stony with some mud, but with patches of clean sand in places. The fauna is poor.

RYE BAY has a rich fauna on a bottom mainly of muddy sand. A number of species common in the western Channel were absent, but such species as Nucula turgida, Tellina fabula, Abra alba and Natica alderi were common. Soft mud, in which the gephyrean Maxmulleria lankesteri was common, occurred both west of Dungeness and in black mud off Hythe to the eastward of this point, where three stations were worked. 


\section{DISTRIBUTION OF THE FAUNA}

Distributions in the Channel in the area surveyed may be classified thus:

(I) Species generally distributed in the Channel.

(2) Species confined to the western parts of the Channel.

(a) 'Western' species mostly restricted at present to the south Cornish coast.

(b) 'Cornubian' species, at the northern end of their range, which penetrate into the Channel from its western end.

(c) 'West Channel' species most of which are widely distributed in European waters, but which disappear abruptly on entering the eastern half of the Channel.

(3) Species distributed around the central region of the Channel.

(4) Northern species, most common in the eastern half of the Channel.

Besides these there are a number of special distributions, including those of shallow-water species, the phenomenon of 'submergence', and the peculiar distribution of Abra prismatica.

Not all the species taken in the survey can be placed in one of the above categories, owing to scarcity of records. It is therefore not possible to discuss in detail the distribution of some species known to have a restricted distribution in British waters, such as Marthasterias glacialis, Ophiocomina nigra, and certain other echinoderms. Dead shell records contribute much to our knowledge of mollusc distributions, so that the distribution pattern for these is more clearly defined than for other phyla.

SPECIES GENERALLY DISTRIBUTED IN THE CHANNEL

This is naturally the largest group, the species of which apparently occur wherever the grade of deposit and other bottom conditions are suitable. The area to the south of the Isle of Wight, being stony, is unsuitable for the majority of burrowing species, but otherwise they are fairly widely distributed. It is noticeable, however, that some are very common in Poole Bay, while others are virtually absent from this area (Fig. 5).

The majority of these species are widely distributed around the British Isles and in European waters:

\begin{tabular}{|c|c|}
\hline Nucula hanleyi & Distribution outside Britain uncertain \\
\hline Nucula turgida & Sweden-Med. ${ }^{1}$ \\
\hline Chlamys opercularis & S. Norway-Med. ${ }^{1}$ (var.), etc. \\
\hline Pecten maximus & S. Norway-Med. ${ }^{1}$ (? var.) \\
\hline Laevicardium crassum & Norway-Med. ${ }^{1}$ (var.) \\
\hline Cardium echinatum & Iceland, N. Norway-Med. ${ }^{1}$ (var.), etc. \\
\hline Lutraria angustior & Distribution outside Britain uncertain \\
\hline Gari fervensis & Iceland, N. Norway-Med. ${ }^{1}$ etc. \\
\hline Abra alba & S. Norway-Med. ${ }^{1}$ \\
\hline
\end{tabular}


Tellina fabula

Phaxas pellucidus

Ensis ensis

Corbula gibba

Nassarius reticulatus

Natica alderi

Ophiura texturata

O. albida

Echinocardium cordatum
S. Norway-Med.

S. Norway-Med.

S. Norway-Med. ${ }^{1}$

Norway-Med. ${ }^{1}$ etc.

S. Norway-Med. ${ }^{1}$

Norway-Med. ${ }^{1}$

Iceland, S. Norway-Med. etc.

Iceland, N. Norway-Med. etc.

1 Species recorded by Bucquoy et al. (1882-98) from the Gulf of Lions, on the Mediterranean coast of France.

There are also three species which here approach the northern end of their range: Diplodonta rotundata, Tellina donacina and Acrocnida brachiata (see Table 4).

Diplodonta and Tellina both occur in south and south-west England (Forbes \& Hanley, I853). It is doubtful if Diplodonta occurs in the Clyde (Scottish Marine Biological Association, I96I) and it is not recorded from Orkney (Rendall, 1956) nor off the east coast of Scotland by McIntyre (1958). $\mathrm{Mr} \mathrm{L}$. Birkett informs me that it occurs living, but very rarely, on the Dogger Bank. It was not recorded in the latter area by Davis (1923, 1925).

Tellina donacina extends a little farther north, being recorded from Orkney, but not off the east coast of Scotland. It was recorded from the central North Sea by Davis (1925), but not by Birkett in recent years.

Acrocnida brachiata occurred regularly in samples throughout the length of the Channel. It sometimes occurs in muddy sand together with Amphiura filiformis but on the whole inhabits less muddy grounds. Ursin (1960) quotes its northern limit as the Swedish west coast, and it seems significant that although not recorded by Davis (1923, 1925) nor mentioned by Stephen (1934) from the North Sea it has more recently been taken at quite a number of stations by Ursin (1960), McIntyre (1958) and Birkett. Ursin considers that the local distribution of this species in the North Sea may be partly related to sea temperatures, and it seems possible that a northward extension of its range has occurred in recent years.

SPECIES CONFINED TO THE WESTERN PARTS OF THE CHANNEL

Western species

Several species were only recorded alive west of Plymouth. A few of these appear to be near their northern limits, and these are described in the next section. The majority, however, are widely distributed north and south of Britain, so that some factor other than temperature may be responsible for their restricted distribution in the Channel. Of these species three or four 

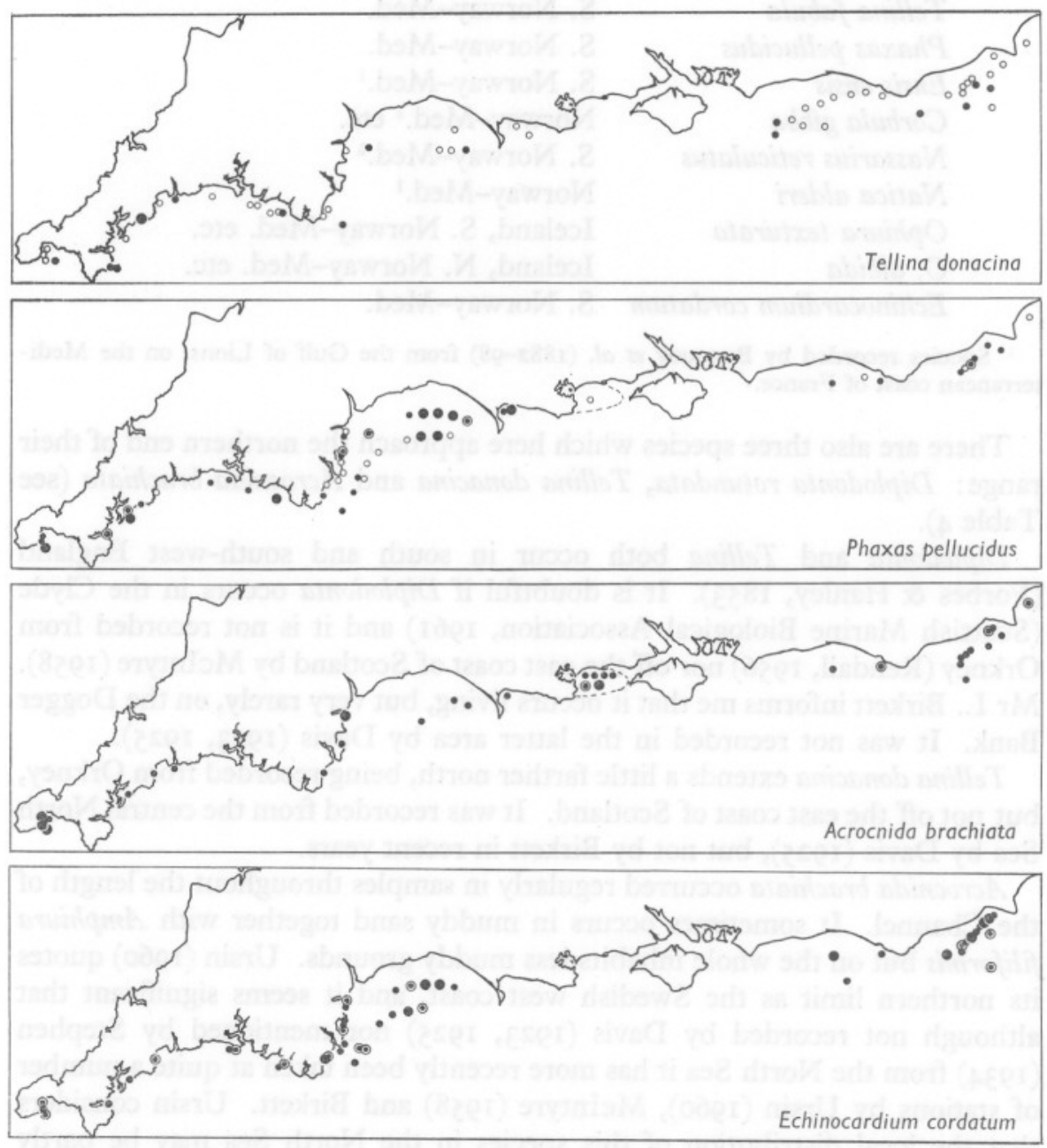

Fig. 5. Occurrence of certain species generally distributed in the Channel, on the basis of the anchor-dredge survey. Positions of stations in Poole Bay are not shown, the area being treated as a whole. $\bigcirc$ dead shells only; (usually an indication that the species is present, but in low density). •, I-4 living per station; $\odot, 5$-10 living; $\bullet,>$ ro living.

have a sufficiently consistent distribution in both the Channel and North Sea to rank as 'indicators' of perhaps 'western', but not necessarily Sagitta elegans, waters. The indicator species have the following common characteristics.

(i) They are generally distributed on the Atlantic coasts of the British Isles (e.g. Nichols, 1900).

(ii) Small numbers are found alive today off the south Cornish coast, from about Looe, westward. 
(iii) The molluscs are represented, as dead shells only, to the eastward no farther than the south-west corner of Great West Bay. Apart from one or two records of single valves south of Rye Bay, there are no records for the rest of the Channel area covered in the survey.

(iv) They were quite common off Plymouth in 1922-23 (Ford, 1923), some occurring in the Sound, but are today absent or very rare offshore (Holme, 1953); while living specimens were recorded in Great West Bay neither by Ford (unpublished data) in 1923 nor by the present author in 1948 (Holme, I950).

(v) Those present in the North Sea are more or less confined to the northwest area off the east coast of Scotland (Stephen, 1933), characterized by Sagitta elegans and S. serratodentata communities (information on plankton communities and the hydrography of the North Sea is summarized by Ursin (1960)).

It will be seen from Table $I$ and Figs. 6 and 7 that the following species fall into this category.

Myrtea spinifera, inhabiting muddy sand, is perhaps the best 'indicator' species. It is widespread, but not particularly common along the west coasts of Britain and Ireland, and I have found it to be a characteristic species in Dingle Bay in west Ireland and in Quiberon Bay in south Brittany. Gouldia (=Gafrarium) minima is a southern form which does not appear to occur, at least in appreciable numbers, in the North Sea; but Tellina pygmaea shows a similar distribution to Myrtea. Thracia villosiuscula is a quite distinct species, although sometimes confused with $T$. phaseolina. Records from the North Sea and other areas are therefore rather uncertain, but in the Channel its distribution is similar to that of the other indicators. Gari tellinella is a little less restricted in distribution, odd valves occasionally being taken at stations up-Channel. Similarly, in the North Sea there is a single record (living) as far south as East Anglia. This species still occurs off Plymouth, but in reduced numbers.

Cochlodesma praetenue is another species with a predominantly western distribution, but the data on this species are insufficient. Off Plymouth it occurs mainly in deeper water near the Eddystone. Ophiocomina nigra also has a western distribution in the Channel, and in the North Sea it occurs mainly in the north-west area, but also in the Kattegat and Øresund (Ursin, 1960). Other species apparently showing a western distribution in the Channel, but for which data are inadequate include:

Gari depressa

G. costulata

Chaetopterus variopedatus

Marthasterias glacialis
Echinocardium pennatifidium

E. flavescens

Holothuria forskali 
TABLE 1. DISTRIBUTION OF WESTERN AND RELATED SPECIES

(For references see Appendix, p. 460. Symbols for habitat are descriptions of sediments as on p. 456.)

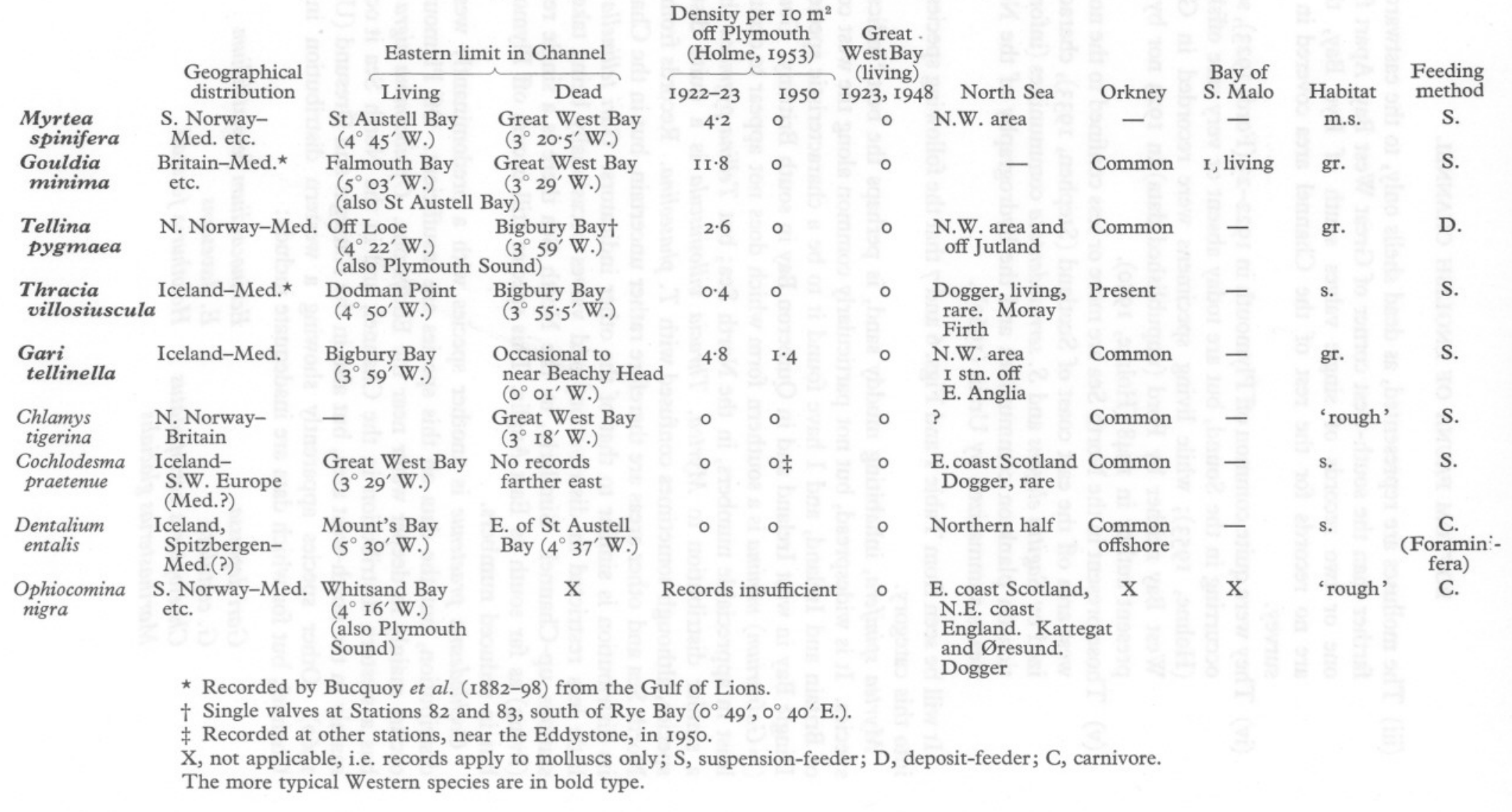


Chlamys tigerina was represented only by dead shells, although it is taken alive off Plymouth, usually perhaps in deeper water. It is a northern species, here near its southern limits, so may be restricted in the Channel by temperature.
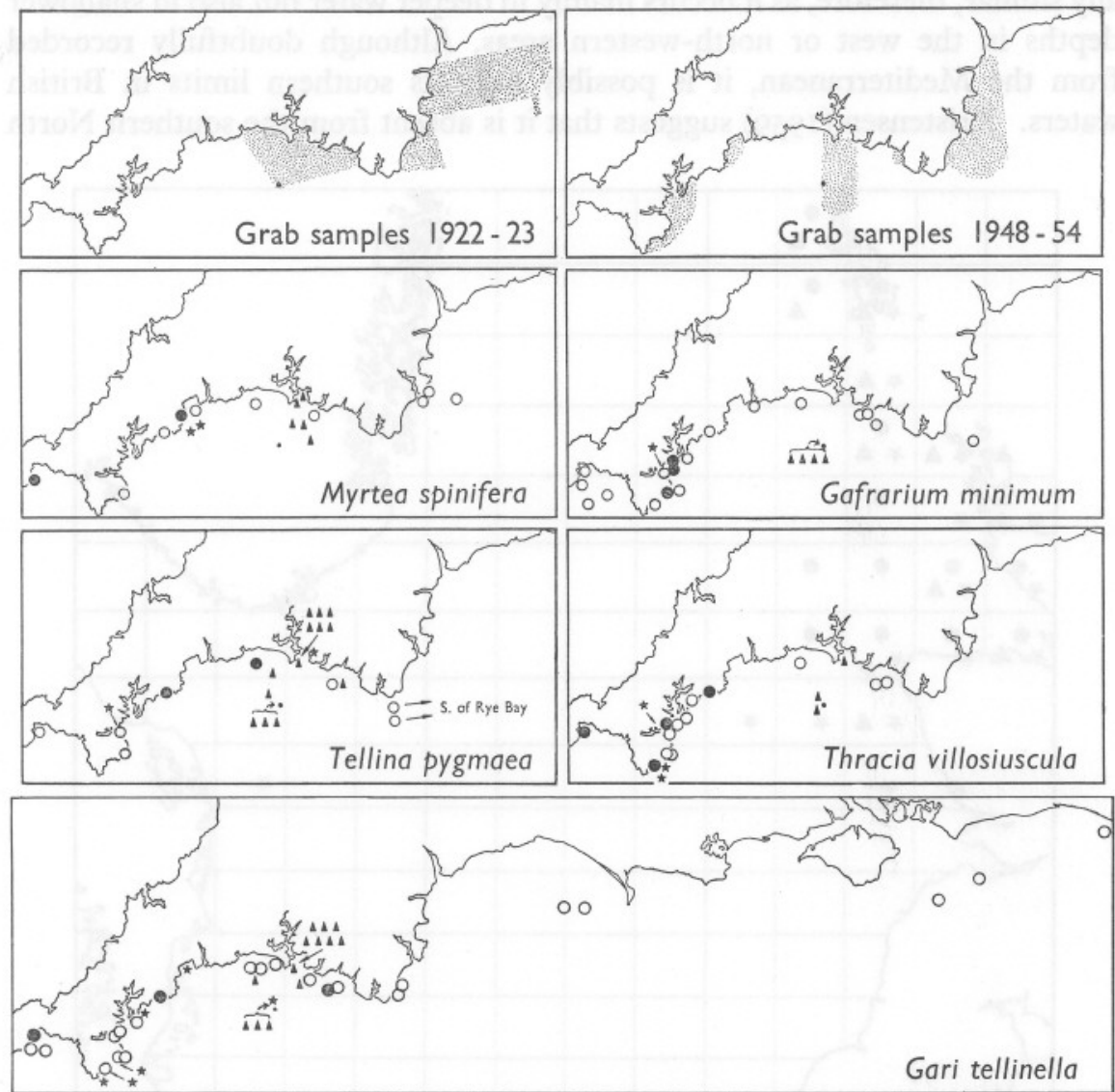

Fig. 6. Distribution of typical Western species. The two upper charts show areas covered by samples other than in the dredge survey (see p. 455). $\bigcirc$, dead shells only; 0 , living specimens. $\star$, other records, I $948-54 ; \boldsymbol{\Delta}$, Ford's records in $1922-23$. There are no records from parts of the Channel not shown, apart from two dead shell records of Tellina pygmaea in the eastern Channel. Gafrarium minimum is a synonym for Gouldia minima.

The distribution of Dentalium entalis (Fig. I0) differs from that of the other species. It was taken living in Mount's Bay at $48 \mathrm{~m}$, and dead-shell records occur to St Austell Bay. I have also taken it living at several positions in midChannel south of Land's End (depth $c a$. $120 \mathrm{~m}$ ), where it is not uncommon. Off Plymouth it was common on the Eddystone grounds at the end of the last century (Allen, I899), but is now absent from this area. Farther west it is a characteristic species in deeper water in the Celtic Sea (Le Danois, I948), and 
in the North Sea it occurs over most of the deeper northern half (Stephen, 1933); McIntyre (1958) records it in only 30-40 m off the east coast of Scotland, however. Its distribution in the Channel and North Sea is essentially similar, therefore, as it occurs mainly in deeper water but also in shallower depths in the west or north-western areas. Although doubtfully recorded from the Mediterranean, it is possibly near its southern limits in British waters. Kristensen (1959) suggests that it is absent from the southern North

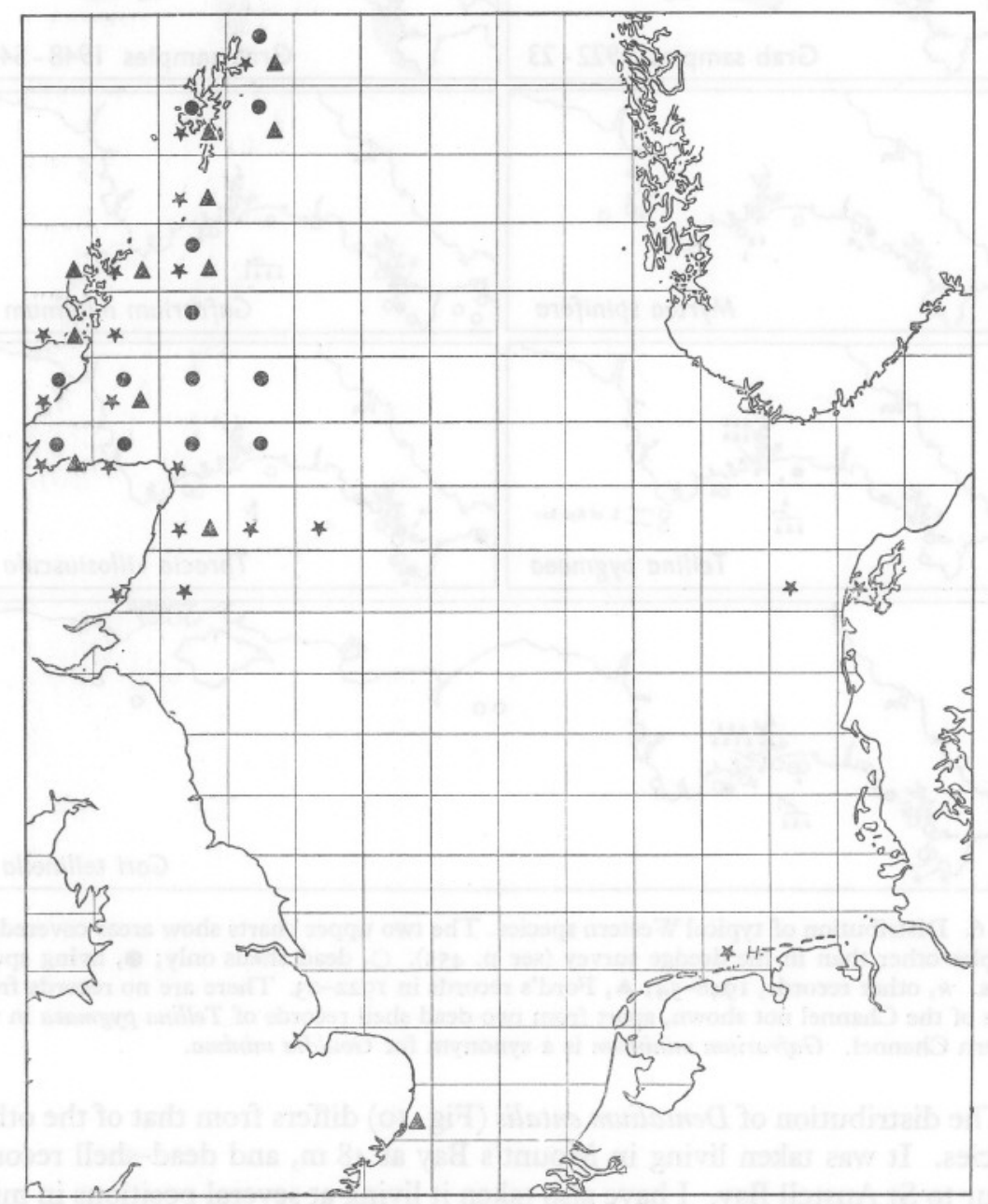

Fig. 7. Distribution of certain Western species in the North Sea, based on Stephen (I933). Occurrence of species in each International Fisheries square is shown. The records include those of Davis (1923, 1925) in the central and southern North Sea, and of Hagmeier (1925) in the German Bight. H, a single record of Tellina pygmaea by Hagmeier; $\bullet$, Myrtea spinifera; $\star$, Tellina pygmaea; $\mathbf{\Delta}$, Gari tellinella. 
Sea because of excessive bottom disturbance there, and this may well be of importance in restricting its distribution. The distribution of D. entalis is almost complementary to that of $D$. vulgare which occurs in the central and eastern Channel (Fig. IO).

The absence of most of the Western species from the Bay of S. Malo suggests that penetration up-Channel on the French coast may be similar to that on the English side.

\section{Cornubian species}

There are a few species (Table 2) whose northern limits lie in British waters and which penetrate a short distance into the Channel from the west. Unlike the more typical Western species of the previous section these show no evidence of a decline in numbers off Plymouth in recent years. An exception is the southern species Gouldia minima, which belongs to the previous section. Although their relative abundance in more western areas (particularly on the shore and in shallow water around Falmouth) may be partly due to the same conditions which also favour Western species, it seems possible that their penetration to the eastward is limited by the lower winter temperatures there.

Around the British Isles these species are mainly restricted to the southwest, being scarce or absent off the Isle of Man, in the Clyde, off Orkney and in the North Sea.

As these species approach the limits of their range they seem to disappear from the shore, but may still be present offshore. This is discussed later, but it may be noted that there appears to be no rigid boundary to the extension of these species, and they may be expected to occur here and there in favourable localities beyond the limits suggested in the table. Labidoplax extends considerably farther up-Channel than the other species, its final limit being perhaps at the boundary of the east and west halves of the Channel.

\section{West Channel species}

Both the Western and Cornubian species discussed above are relatively uncommon in the areas of the Channel in which they occur, but there are also many species both widely distributed and common in north European waters which are absent from that part of the eastern Channel covered by the survey. They do not gradually decline in numbers on passing up-Channel, indeed many are more common in Great West Bay than farther west, but all disappear abruptly near the boundary between the west and east halves of the Channel, in the region of St Alban's Head. Weymouth Bay provides the most easterly record for many, and apart from Amphiura filiformis none was found living in Poole Bay. Dead shell records from the eastern Channel are negligible, and the only species found alive was one Dosinia exoleta south of Rye Bay (station 8I). The apparent sharpness of this boundary is probably enhanced by three factors. One is related to conditions in Poole Bay which 
TABLE 2. DISTRIBUTION OF CORNUBIAN SPECIES

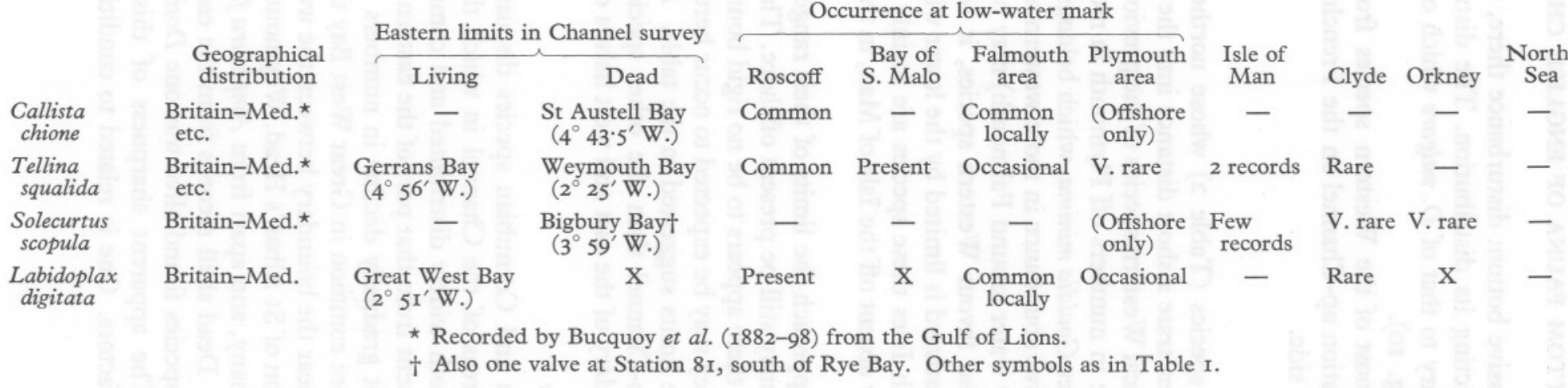


appear to be unfavourable to certain species distributed throughout the Channel (p. 406) and which might be similarly unfavourable to West Channel species. The second is the nature of grounds south of the Isle of Wight, which are stony and tide-swept, and the third is related to the sampling techniques.

At stations $\mathrm{I}-\mathrm{IO}$ in Weymouth Bay and II-25 in Poole Bay, dead shell records are not complete as they represent merely a selection of species, other than those found living, without any attempt at a comprehensive list. No species occurring in any numbers could have been missed, but some of the scarcer ones may have been overlooked. Stations $26-40$, also in Poole Bay, are

TABLE 3. DISTRIBUTION, HABITAT AND FEEDING HABITS OF WEST CHANNEL SPECIES

\begin{tabular}{|c|c|c|c|c|c|}
\hline & $\begin{array}{l}\text { Geographical } \\
\text { distribution }\end{array}$ & Orkney & $\begin{array}{c}\text { Central and } \\
\text { southern N. Sea }\end{array}$ & Habitat & $\begin{array}{c}\text { Feeding } \\
\text { habits }\end{array}$ \\
\hline Lucinoma borealis & $\begin{array}{l}\text { N. Norway- } \\
\text { Med. etc. }\end{array}$ & Common & $\begin{array}{l}\text { At } 8 \text { stations } \\
\text { (Davis) }\end{array}$ & s. & S. \\
\hline Dosinia exoleta & $\begin{array}{l}\text { N. Norway- } \\
\text { Med.` }\end{array}$ & Common & $\begin{array}{l}\text { At I8 stations } \\
\text { (Davis) }\end{array}$ & gr. & S. \\
\hline D. lupinus & $\begin{array}{l}\text { Iceland, } \\
\text { S. Norway-Med }\end{array}$ & $\begin{array}{l}\text { Common } \\
\text { d. }{ }^{\star}\end{array}$ & $\begin{array}{l}\text { Dogger, } \\
\text { uncommon }\end{array}$ & s. & S. \\
\hline Venus casina & $\begin{array}{l}\text { S. Norway- } \\
\text { Med.` }\end{array}$ & $\begin{array}{l}\text { Common, } \\
\text { local }\end{array}$ & - & gr. & S. \\
\hline V. fasciata & $\begin{array}{l}\text { S. Norway- } \\
\text { Med. }\end{array}$ & Common & $\begin{array}{r}\text { Common } \\
\text { (Birkett) }\end{array}$ & gr. & S. \\
\hline V. striatula & $\begin{array}{l}\text { N. Norway- } \\
\text { Med.` }\end{array}$ & Common & Common & s. & S. \\
\hline Arcopagia crassa & $\begin{array}{l}\text { S. Norway- } \\
\text { Med. (?) }\end{array}$ & Local & $\begin{array}{l}\text { Dogger, v. rare } \\
\text { (Birkett) }\end{array}$ & gr. & Selective D. \\
\hline $\begin{array}{l}\text { Solecurtus } \\
\text { chamasolen }\end{array}$ & $\begin{array}{l}\text { S. Norway- } \\
\text { Med.` etc. }\end{array}$ & - & - & m.s. & S. \\
\hline Thracia phaseolina & $\begin{array}{l}\text { Iceland-Med. }{ }^{\star} \\
\text { etc. }\end{array}$ & Common & Dogger (Birkett) & s. & S. \\
\hline Pandora pinna & $\begin{array}{l}\text { Scandinavia } †- \\
\text { Med. etc. }\end{array}$ & - & - & s. & S. \\
\hline $\begin{array}{l}\text { Turritella } \\
\text { communis }\end{array}$ & $\begin{array}{l}\text { S. Norway- } \\
\text { Med.` etc. }\end{array}$ & Common & Fairly common & m.gr. & S. \\
\hline $\begin{array}{l}\text { Callianassa } \\
\text { subterranea }\end{array}$ & British Isles & $\mathrm{X}$ & $\begin{array}{l}\text { At } 5 \text { stations } \\
\text { (Davis) }\end{array}$ & f.s. & D.? \\
\hline Upogebia stellata & $\begin{array}{l}\text { Sweden-Med. } \\
\text { etc. }\end{array}$ & $\mathrm{x}$ & - & m.gr. & S., C.? \\
\hline $\begin{array}{l}\text { Astropecten } \\
\text { irregularis }\end{array}$ & $\begin{array}{l}\text { Iceland, } \\
\text { S. Norway-Med }\end{array}$ & $\mathrm{X}$ & $\begin{array}{l}\text { Generally } \\
\text { distributed }\end{array}$ & s. & C. \\
\hline Amphiura filiformis & $\begin{array}{l}\text { Iceland, } \\
\text { S. Norway-Med }\end{array}$ & $\mathrm{X}$ & $\begin{array}{l}\text { Generally } \\
\text { distributed }\end{array}$ & m.s. & Selective D. \\
\hline Ophiura affinis & $\begin{array}{l}\text { Iceland, } \\
\text { N. Norway-Med }\end{array}$ & d.(?) & $\begin{array}{l}\text { Generally } \\
\text { distributed }\end{array}$ & s. & ? \\
\hline Cucumaria elongata & $\begin{array}{l}\text { S. Norway- } \\
\text { Med. }\end{array}$ & $\mathrm{X}$ & $\begin{array}{l}\text { Local, S.W. and } \\
\text { E. of Dogger }\end{array}$ & $\mathrm{m}$. & S. \\
\hline $\begin{array}{l}\text { Leptosynapta } \\
\text { inhaerens }\end{array}$ & $\begin{array}{l}\text { S. Norway- } \\
\text { Atlantic coast } \\
\text { of France }\end{array}$ & $\mathrm{X}$ & $\begin{array}{l}\text { At } 9 \text { stations } \\
\text { (Davis) }\end{array}$ & m.s. & $\begin{array}{l}\text { Non-selective } \\
\text { D. }\end{array}$ \\
\hline
\end{tabular}

* Recorded by Bucquoy et al. (1882-98) from the Gulf of Lions.

† Jeffreys (1862-9) states that this species ranges northward to Spitzbergen. This is incorrect and may be due to confusion with Pandora glacialis Leach.

Symbols as in Table I, p. 3 ro, and for habitat as on p. 456. 
still less complete, and do not necessarily include all living specimens, and dead shells are not usually recorded. In all, thirty stations were worked in the small area of Poole Bay, so that positive records are probably fairly complete.

\section{TABLE 4. OCCURRENCE OF WEST CHANNEL SPECIES ALONG THE CHANNEL}

Occurrence noted in each of the fourteen areas of the Channel (see Fig. 4). Numbers of stations at which each species was recorded are shown. Records from other stations additional to those representing each area are shown, preceded by a plus sign. D, only dead shells recorded; (D), only one or two shells or valves recorded in all.

In this and succeeding tables additional records for Poole Bay are all included in area 10.

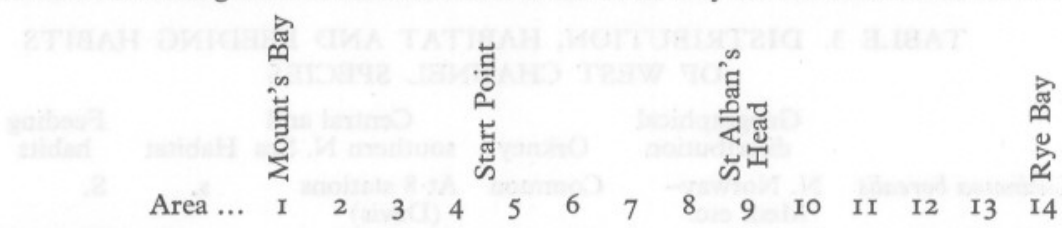

West Channel species

Lucinoma borealis

Dosinia exoleta

D. lupinus

Venus casina

V. fasciata

V. striatula

Arcopagia crassa

Solecurtus chamasolen

Thracia phaseolina

Pandora pinna

Turritella communis

Callianassa subterranea

Upogebia stellata

Astropecten irregularis

Amphiura filiformis

Ophiura affinis

Cucumaria elongata

Leptosynapta inhaerens

\begin{tabular}{|c|c|c|c|c|c|c|c|c|c|c|c|c|c|}
\hline & $2+1$ & D & $\mathrm{I}$ & D & - & - & I & - & - & - & - & - & (D) \\
\hline 2 & 2 & D & D & D & - & D & D & D & - & - & - & - & 1 \\
\hline & $3+1$ & 4 & 3 & D & D & 3 & D & - & - & - & - & - & \\
\hline D & & D & & - & - & & D & 2 & - & - & - & & \\
\hline & 3 & I & D & & $\bar{z}$ & D & I & D & - & - & - & (D) & - \\
\hline & $3+1$ & D & & & 7 & 5 & 5 & & 二 & 二 & 二 & & \\
\hline & D & & & - & 4 & & $\mathrm{D}$ & & $\bar{z}$ & 二 & 二 & 二 & \\
\hline & 2 & & - & & & & $\mathrm{D}$ (?) & - & - & - & & - & \\
\hline & I & - & & & - & & $I(?)$ & - & - & - & (D) & - & \\
\hline & $+\mathrm{I}$ & I & I & & & & & - & (D) & - & - & - & \\
\hline & - & I & I & & 6 & & & - & - & - & - & - & \\
\hline & I & & & & - & & & & - & - & - & - & \\
\hline & 3 & & & & & & & - & - & - & - & - & \\
\hline & - & 4 & & & IO & & 5 & - & $2+I$ & - & - & - & \\
\hline & & & & & & & 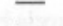 & & & 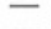 & - & - & \\
\hline & & & & & & & & & & - & - & - & \\
\hline & & & & & & & & & & & - & & \\
\hline
\end{tabular}

Southern species, generally distributed in Channel (for comparison)

Diplodonta rotundata
Tellina donacina

Acrocnida brachiata $\begin{array}{cccccccccccccc}\text { I } & \text { I + I } & \text { I } & \text { I } & \text { I } & \text { D } & 2 & \text { I } & - & - & \text { I } & \text { I } & \text { D } & 2 \\ \text { I } & 2+\text { I } & \text { I } & \text { I } & \text { I } & \text { D } & \text { I } & \text { I } & \text { D } & - & 2 & \text { D } & 3 & \text { I } \\ 4 & \text { I } & 2 & - & \text { I } & \text { I } & 2 & 3 & - & 5+I & - & 2 & 5 & 4+\text { I }\end{array}$

'Negative records' provided by the absence of both living specimens and dead shells are however less reliable. At more offshore stations (96-IOI) in the area a complete record was taken. So far as they go these do not dispute the view that the boundary of West Channel species lies in the St Alban's Head region.

Hardly any of the West Channel species appear to be at the limit of their geographical range in the Channel (Table 3), and their distribution (Table 4, Figs. 8, 9) may be contrasted with those of the southern species which occur mainly in the central area of the Channel (p. 4I9), or with the three southern species shown in the table which are present throughout the length of the Channel.

The local distribution of West Channel species within the western half of 

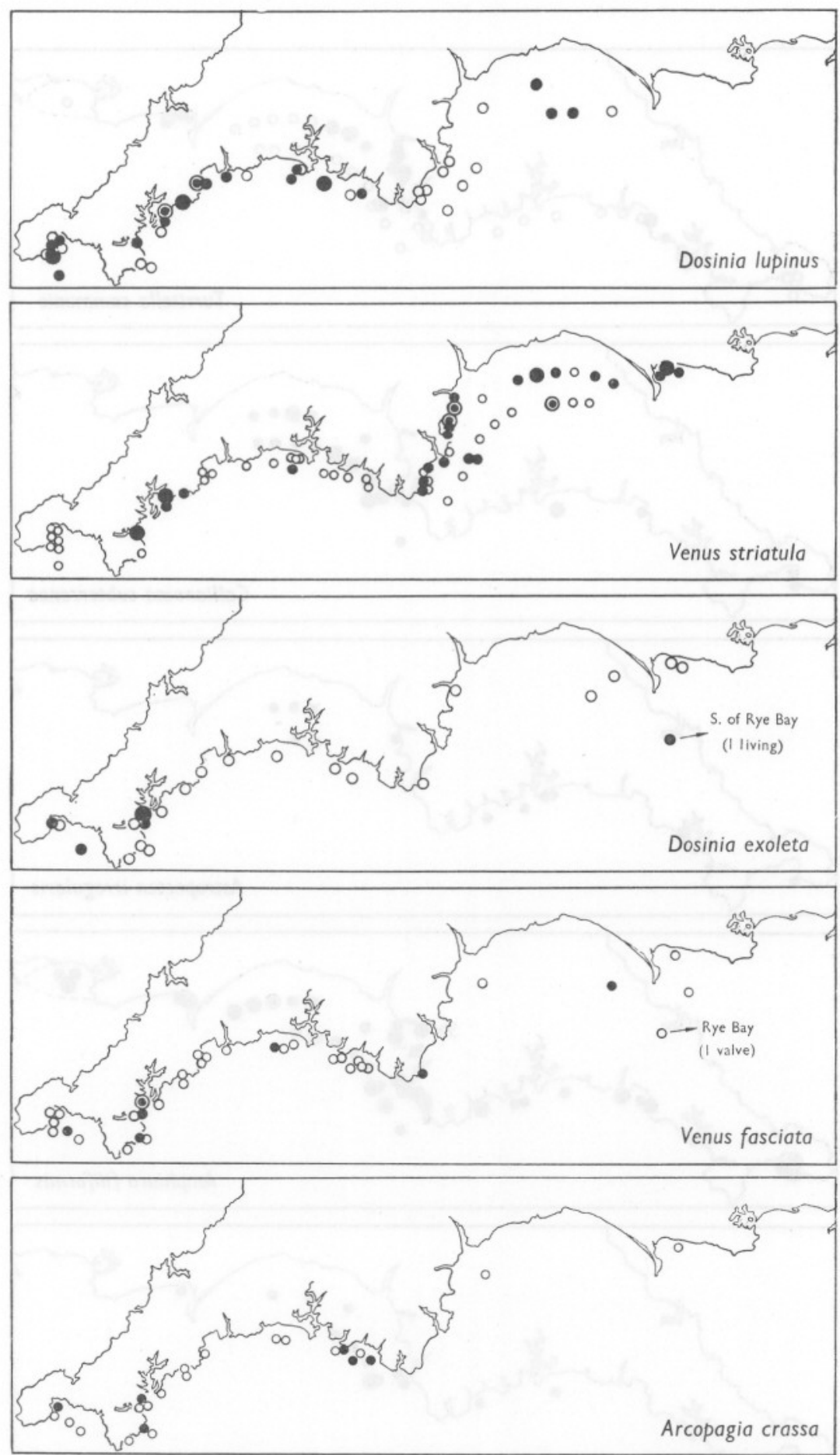

Fig. 8. Distribution of some West Channel lamellibranchs, showing also the effect of soil grade on local distribution. Dosinia lupinus and Venus striatula inhabit sands, the rest gravels. Symbols as in Fig. 5, p. 408. 

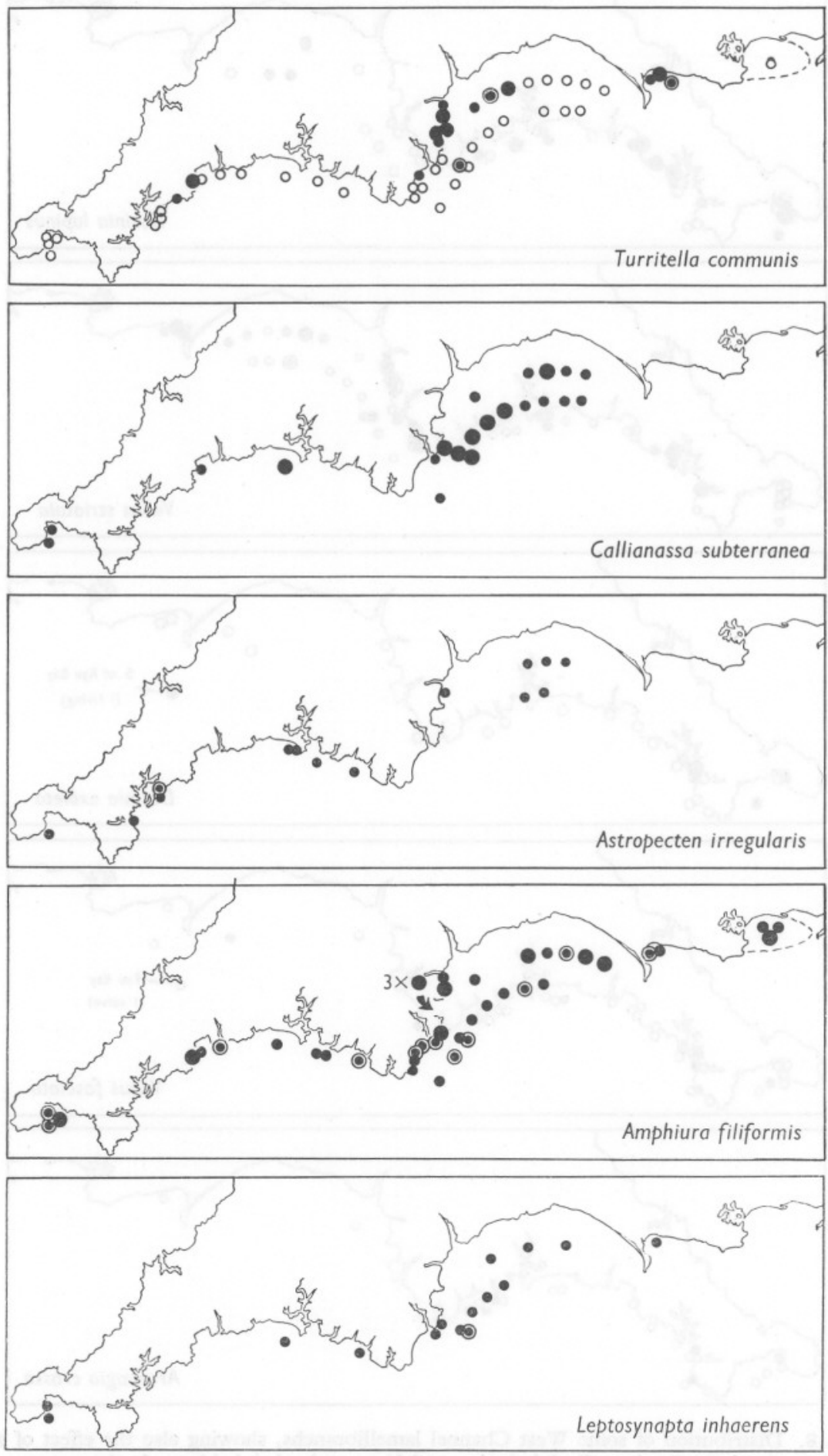

Fig. 9. Distribution of some more West Channel species. Symbols as in Fig. 5, p. 408, except for Turritella, where the density scale is: •, I-IO; $\odot, \mathrm{II}-\mathrm{I00}$;,$>$ I00. 
the Channel appears to be mainly related to soil preferences. There is a close similarity in the distributions on the one hand of Dosinia exoleta, Venus fasciata and Arcopagia crassa inhabiting gravels and on the other of Dosinia lupinus and Venus striatula inhabiting sands (Fig. 8). Some of the less common species are rather patchy in distribution and some difficulty was experienced in deciding if Lucinoma borealis, for example, really belonged to this category. In addition to the species listed, there are a few others which appear to be mainly confined to the western Channel. These include Glycymeris glycymeris, Thyasira flexuosa and Lutraria lutraria.

Feeding habits, so far as they are known, are given in the table. It will be seen that among the lamellibranchs there is a preponderance of suspension feeders, suggesting that some factor such as suspended silt might be responsible for their absence from the eastern Channel. The possible causes of the boundary are discussed later, but it may be remarked at this stage that species occurring in the eastern basin do include a number of suspension feeders, such as Ensis spp., Spisula spp. and Venus ovata.

SPECIES DISTRIBUTED AROUND THE CENTRAL REGIONS OF THE CHANNEL

These reach their maximum abundance between Start Point and Beachy Head. West of Start Point they become rare or are even absent, but some occur between tide marks in the Falmouth area (Fig. I0). To the east they mainly range as far as the dredge survey was carried, and no doubt some occur along the Belgian and Dutch coasts. This group is made up primarily of species near the northern end of their range, but with them are listed certain other species (Venus ovata, Spisula subtruncata, Crepidula fornicata) showing a similar distribution (Tables 5, 6).

The southern forms generally occur in greater abundance off the French coast, particularly in the Channel Islands-S. Malo region, and are therefore referred to here as Sarnian species. Many inhabit rather shallow water, and also occur at low water, particularly on the French coast. As they approach their northern limits there is a tendency for them to occur only offshore and not between tide marks. Some appear to have a bimodal distribution in the Channel: for example Chlamys varia and Venerupis aurea occur offshore in the central Channel, are rare or absent at Plymouth, and again appear as common species at low water in the Falmouth area. It is curious that offshore records of Chlamys varia in the Falmouth area are virtually nil, suggesting an elevation of the depth range inhabited rather than an extension on to the shore from offshore grounds.

Although found more commonly offshore at Plymouth, Gibbula magus and Calyptraea chinensis tend to a similar bimodal distribution. (The distribution of G. magus is discussed by Crisp \& Southward, 1958). Both Dentalium vulgare and Nassarius pygmaeus are virtually restricted to grounds east of 

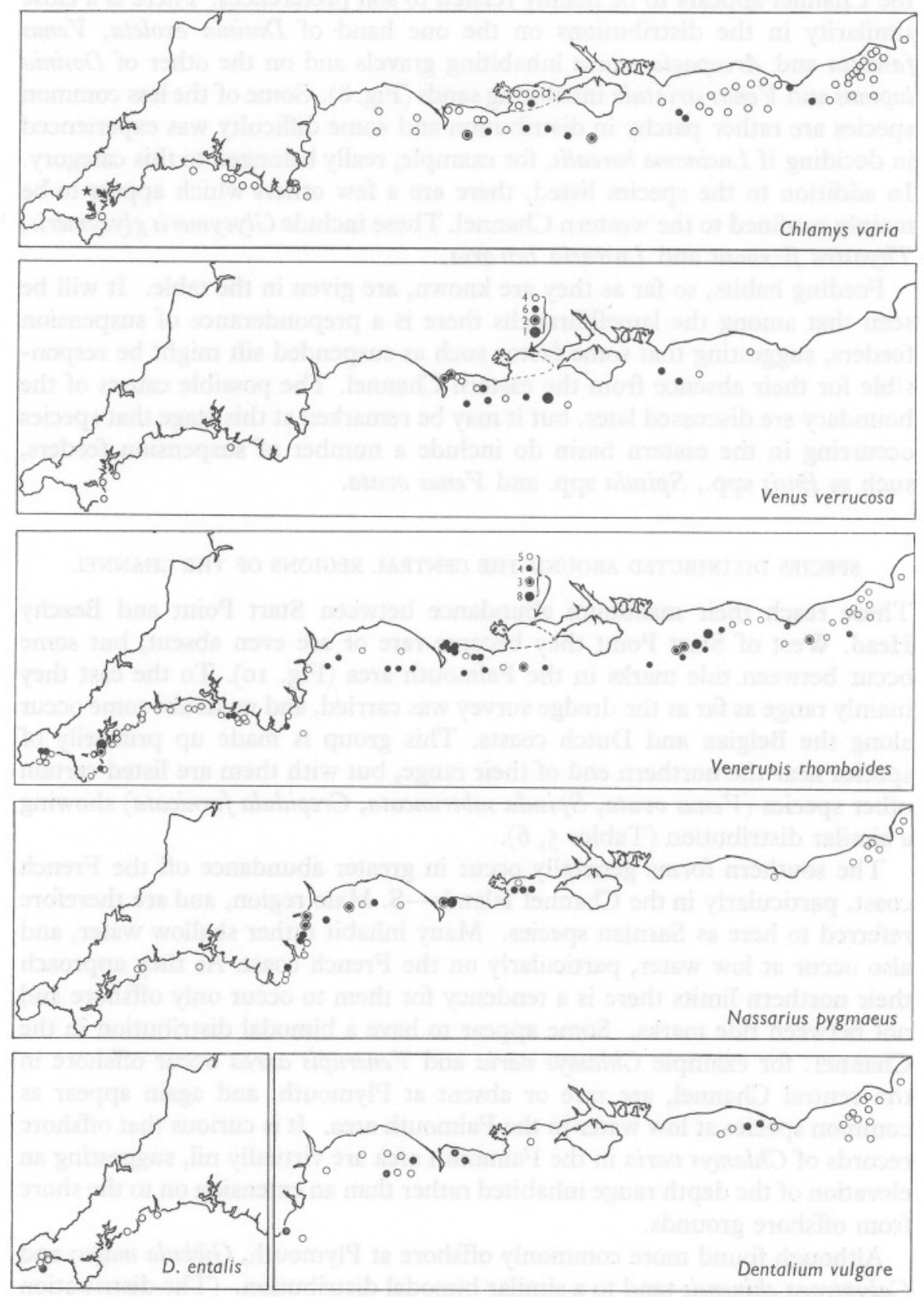

Fig. Io. Distribution of some Sarnian species, also of Dentalium entalis as contrasted with D. vulgare. Symbols as in Fig. 5, p. 408. $\star$, shore records of Chlamys varia. 
TABLE 5. OCCURRENCE OF SPECIES DISTRIBUTED AROUND THE CENTRAL REGIONS OF THE CHANNEL

\begin{tabular}{|c|c|c|c|c|c|c|c|c|}
\hline & Geographical distribution & Roscoff & $\begin{array}{l}\text { Bay of } \\
\text { S. Malo }\end{array}$ & $\begin{array}{l}\text { Falmouth } \\
\text { area }\end{array}$ & $\begin{array}{l}\text { Plymouth } \\
\text { area }\end{array}$ & Clyde & Orkney & North Sea \\
\hline Nucula nucleus & S. Norway-Med.` & C. $\dagger$ & C. & $\begin{array}{l}\text { Probably } \\
\text { present }\end{array}$ & Occ. & C. & C. & $\begin{array}{l}\text { N.E. coast Scot- } \\
\text { land, Dogger, etc. }\end{array}$ \\
\hline Chlamys varia & S. Norway-Med.^ etc. & Quite C.† & C. $\dagger$ & $\mathrm{C}+$ & R.t & Scarcet & C. & At I station \\
\hline $\begin{array}{l}\text { Venus verrucosa } \\
\text { V. ovata } \\
\text { Venerupis rhomboides } \\
\text { V. aurea }\end{array}$ & 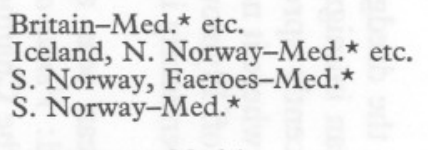 & $\begin{array}{l}\text { Quite C. } \dagger \\
\text { C. offshore } \dagger \\
\text { C. offshore } \\
\text { C. } \dagger\end{array}$ & $\begin{array}{l}\text { Abundant } \dagger \\
\text { C. offshore } \dagger \\
\text { C. } \dagger \\
\text { Abundant }\end{array}$ & $\begin{array}{l}\text { ? R.t } \\
\text { ? Occ. } \\
\text { C. } \\
\text { C. } t\end{array}$ & $\begin{array}{l}\text { Occt. } \\
\text { Occ. } \\
\text { C. offshoret } \\
\end{array}$ & $\begin{array}{l}\text { R. } \\
\text { Fairly C. } \\
\text { Occ. } \\
\text { R. }\end{array}$ & $\begin{array}{l}\text { C. } \\
\text { C. }\end{array}$ & $\begin{array}{l}\text { Present - } \\
\text { Dead shells, } \\
\text { Dogger (Birkett) }\end{array}$ \\
\hline Spisula subtruncata & N. Norway-Med.* & Occ.† & Present $\dagger$ & Occ. $\dagger$ & Occ. & C. $†$ & $\begin{array}{l}\text { Moderately } \\
\text { C. (? on } \\
\text { shore) }\end{array}$ & $\begin{array}{l}\text { common than } \\
\text { formerly } \\
\text { (Birkett, Ursin) }\end{array}$ \\
\hline $\begin{array}{l}\text { Pandora albida } \\
\text { Dentalium vulgare }\end{array}$ & $\begin{array}{l}\text { Isle of Man-Med. } \\
\text { Britain-Med.` etc. }\end{array}$ & $\begin{array}{l}\text { Quite C.† } \\
\text { Occ. } \dagger\end{array}$ & $\begin{array}{l}\text { Occ. } \dagger \\
\text { C. } \dagger\end{array}$ & - & R.t & - & - & - \\
\hline Calliostoma zizyphinum & Norway-Med.` & C.t & C.t & Present & C.t & & C.t & $?$ \\
\hline Gibbula magus. & Britain-Med.` etc. & C. $†$ & C. & Quite C.t & R.t. & Fairly C. $†$ & C.t & $?$ \\
\hline Calyptraea chinensis & Britain-Med.^ etc. & C. $\dagger$ & C. $\dagger$ & C.t & $\begin{array}{l}\text { Quite C. } † \\
\text { (occ. on } \\
\text { shore) }\end{array}$ & $\begin{array}{l}\text { Common, } \\
\text { L. Ryan } \\
\text { (? introdu }\end{array}$ & ced) & ? \\
\hline Crepidula fornicata & Introduced & - & - & See Colet & R.t & - & - & ? \\
\hline Nassarius pygmaeus & S. Norway-Med. ${ }^{\star}$ etc. & R. & Uncommon† & 1952 & V.R. & R. & - & ? \\
\hline
\end{tabular}


Start Point, but the majority of other Sarnian species do occur here and there along the coasts west of this headland. Venerupis rhomboides is quite common throughout the Channel, but is particularly abundant in the central area, especially in Poole Bay. Calliostoma zizyphinum, usually known as a rocky shore form, was taken offshore in the central and eastern areas of the Channel, but was represented only by a single dead-shell record west of Start Point. Crisp \& Southward's (1958) data on this species, however, suggest that this species is confined on the shore to the western half of the Channel, both on the French and English coasts. This appears to be another example of an elevation of the depth range in more western areas.

TABLE 6. OCCURRENCE OF CENTRAL CHANNEL SPECIES ALONG THE CHANNEL

Occurrence noted in each of the I4 areas. For symbols see Table 4

\begin{tabular}{|c|c|c|c|c|c|c|c|c|c|c|c|c|c|c|}
\hline & $\begin{array}{l}0 \\
\infty \\
\dot{3} \\
\dot{3}\end{array}$ & & & & : & & & & 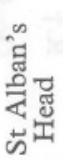 & & & & & 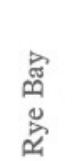 \\
\hline Area ... & I & 2 & 3 & 4 & 5 & 6 & 7 & 8 & 9 & Io & II & 12 & I3 & I4 \\
\hline Nucula nucleus ${ }^{\star}$ & 一 & $\bar{D}$ & $\bar{D}$ & $\bar{n}$ & - & - & I & 2 & 3 & $4+4$ & $\mathbf{I}$ & $\bar{D}$ & I & \\
\hline Chlamys varia & - & D & D & D & I & - & D & D & 2 & $2+1$ & 4 & D & 2 & \\
\hline $\begin{array}{l}\text { Venus verrucosa } \\
V \text { ovata }\end{array}$ & $\bar{D}$ & D & $\overline{\mathrm{D}}$ & $\mathrm{D}$ & $\bar{r}$ & $\bar{I}$ & $\bar{T}$ & 2 & 4 & $2+8$ & 2 & D & $\overline{\mathrm{D}}$ & \\
\hline $\begin{array}{l}\text { Vevata } \\
\text { Venerupis rhomboides }\end{array}$ & $\begin{array}{l}D \\
2\end{array}$ & $\begin{array}{l}\mathrm{D} \\
3\end{array}$ & $\begin{array}{l}\mathrm{D} \\
\mathrm{D}\end{array}$ & $\begin{array}{l}\mathrm{I} \\
\mathbf{2}\end{array}$ & $\begin{array}{l}\mathrm{I} \\
\mathrm{I}\end{array}$ & $\stackrel{\text { I }}{\mathrm{D}}$ & $\begin{array}{l}1 \\
3\end{array}$ & $\begin{array}{l}2 \\
6\end{array}$ & $\begin{array}{l}3 \\
7\end{array}$ & $\begin{array}{l}I+4 \\
4+I I\end{array}$ & $\begin{array}{l}4 \\
6\end{array}$ & $\begin{array}{l}\mathrm{D} \\
2\end{array}$ & $\begin{array}{l}D \\
3\end{array}$ & L \\
\hline V. aurea & - & -十 & $=$ & - & - & - & - & 2 & - & - & - & $=$ & & \\
\hline Spisula subtruncata & D & I & $\mathrm{D}$ & D & 2 & 3 & 3 & 6 & - & $2+3$ & - & D & D & \\
\hline Pandora albida & - & - & 一 & - & 一 & - & 一 & I & - & I & 一 & I & $\bar{\pi}$ & \\
\hline Dentalium vulgare & 一 & 一 & - & $\overline{-}$ & I & - & I & I & 2 & D & 一 & 2 & D & \\
\hline Calliostoma zizyphinum & $\bar{n}$ & $\bar{n}$ & $\bar{n}$ & D & I & D & D & - & 3 & I & 2 & D & I & \\
\hline Gibbula magus. & $\mathrm{D}$ & D & $\mathrm{D}$ & - & $\mathrm{D}$ & $\bar{\pi}$ & - & 2 & I & - & $\bar{\pi}$ & - & D & \\
\hline Calyptraea chinensis & & I & 二 & 二 & I & $\mathrm{D}$ & I & 2 & $\overline{0}$ & $+\mathrm{I}$ & $\mathrm{D}$ & $\bar{x}$ & - & \\
\hline Crepidula fornicata & - & - & $\overline{\mathrm{D}}$ & $\bar{n}$ & 3 & I & D & 3 & 3 & $6+4$ & 4 & I & $\mathrm{I}$ & \\
\hline assarius pygmaeus & & - & $D$ & D & I & 3 & 4 & 2 & & 3 & & D & D & \\
\hline
\end{tabular}

The distribution of Crepidula fornicata in the dredge survey accords with what is already known of this North American immigrant. It has long been established in the Solent, and has more recently spread westward, first to Weymouth Bay and then to Great West Bay, where it now occurs in moderate numbers (Orton, 1950). It is still rather rare off Plymouth (Marine Biological Association, 1957), but was introduced independently into the Falmouth area (Cole, 1952).

Two species widely dispersed in European seas are at present mainly confined to the central areas of the Channel: Venus ovata and Spisula subtruncata. Dead shells occurred throughout the Channel, but live specimens, sometimes in considerable numbers, were taken mainly between Start Point and the Isle of Wight (Fig. II). Both still occur off Plymouth, where there is evidence (Holme, 1953) of a decline in numbers of Venus ovata between 
1922-23 and 1950. Comparable data for Spisula subtruncata are insufficient. Possibly the more muddy grounds in Great West Bay, Weymouth Bay and Poole Bay are particularly favourable for both these inhabitants of muddy sands, but in S. subtruncata there is evidence of a former decline in northern British waters (Elmhirst \& Stephen, 1929; Fisher, I93I), and in the North Sea where it is no longer the dominant species on the Dogger Bank (Ursin, 1952; Birkett, I953). It is possible that the restricted distribution of Spisula in the Channel is a reflexion of such a general decline and may represent either a partial withdrawal to a more favourable environment in the central Channel or to an overall decline in density throughout the Channel.

The species in this section are, by definition, not confined to the western half of the Channel. It would seem possible however that certain Sarnian species might be prevented from entering the eastern Channel for the same causes which exclude the typical West Channel species. Such species would be mainly confined, on the English side, to Great West Bay, and possibly occur in smaller numbers farther west. Callianassa subterranea (Fig. 9) may possibly be an example of this type of distribution.

\section{NORTHERN SPECIES}

One or two northern species (e.g. Chlamys tigerina; possibly also Dentalium entalis) are restricted to the western parts of the Channel, but two other species Spisula elliptica and Buccinum undatum are mainly confined to the central and eastern areas. Their distribution in the Channel (Table 7, Fig. II)

TABLE 7. OCCURRENCE OF SOME NORTHERN SPECIES (ALSO APHRODITE) ALONG THE CHANNEL

Occurrence noted in each of the I4 areas. For symbols see Table 4

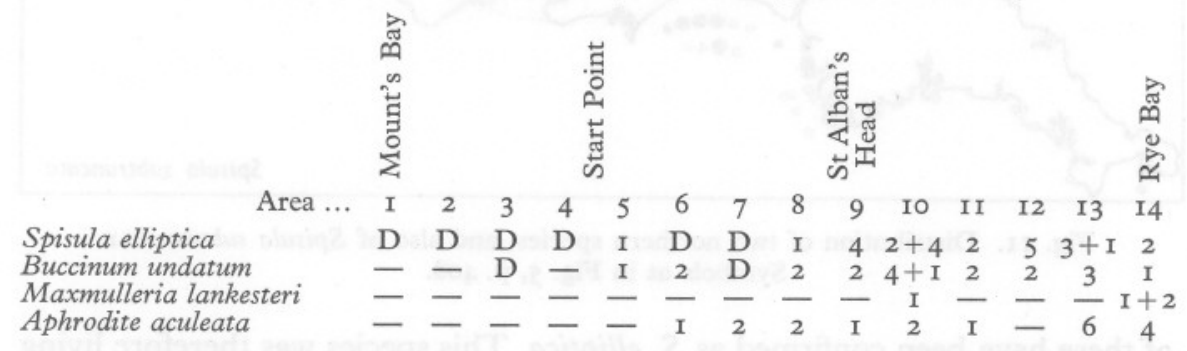

is not in fact very different from that of many southern species described in the last section, but whereas the latter may be influenced by high summer temperatures, the northern species are perhaps dependent on the lower winter temperatures which occur in the eastern Channel.

The exact geographical range of Spisula elliptica is uncertain, owing to possible confusions of identity, but it appears to range at least from Iceland to the British Isles (Madsen, 1949). It may extend down the west coast of 
France, but is absent from the Mediterranean. In the dredge survey it was taken living from Start Point eastward, occurring mainly in the eastern half of the Channel. Dead shells only were recorded westward to Mount's Bay. Ford (1923, 1925) describes it as common off Plymouth, but insufficient material is now available to check his records, some of which were in fact of S. solida (see Appendix). The late Dr D. Atkins has kindly shown me shells of specimens used for her work on ciliary currents (see Appendix), and some
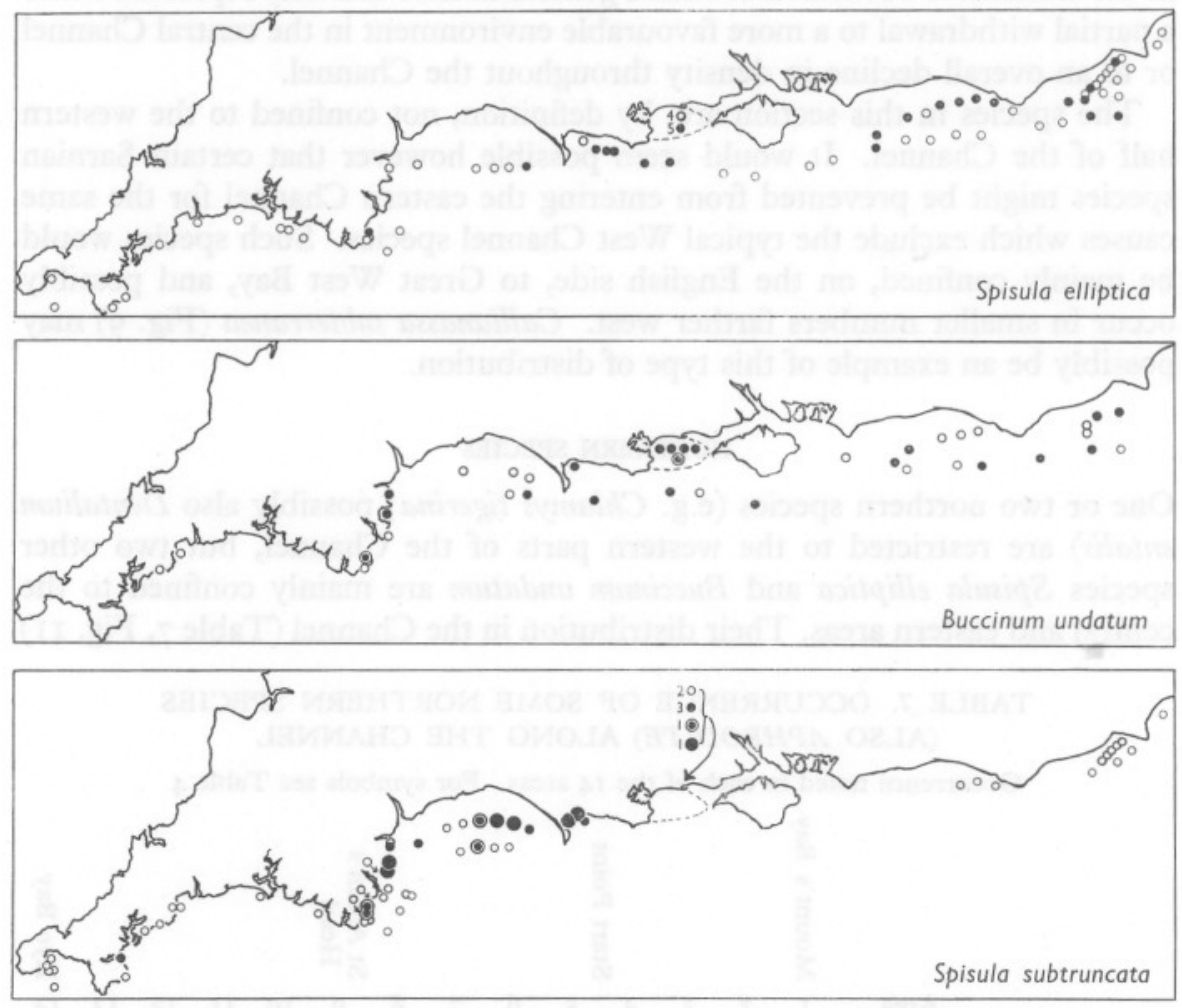

Fig. II. Distribution of two northern species, and also of Spisula subtruncata. Symbols as in Fig. 5, p. 408.

of these have been confirmed as S. elliptica. This species was therefore living in the Plymouth area in the 1930's, at least, but its presence here in the 1960's has yet to be established.

According to Jeffreys (1862-69), Buccinum undatum occurs from Spitzbergen to La Rochelle. I have recently (1960) taken it alive in Quiberon Bay, so that it still extends into the Bay of Biscay. In the dredge survey it was quite common east of Start Point, but to the west was represented by only two records of dead shells. It is, however, regularly taken in small numbers when 
trawling off Plymouth and also at low tide on the shore, particularly in January and February when it comes in to spawn. Offshore it is evidently sparsely distributed, and was not recorded in the photographic survey of the sea-bed off Plymouth made by Vevers (1952). Its absence in the dredge samples illustrates the limitations of the anchor-dredge (or grab) for sampling larger members of the fauna, particularly epifauna species which may be highly gregarious. On the other hand, the regular occurrence of Buccinum in dredge-hauls east of Start Point shows that it is very much more common in that area.

The echiuroid Maxmulleria (= Thalassema) lankesteri was taken in soft muddy deposits both in Poole Bay and around Dungeness. There are not very many records of the occurrence of this species (Stephen, 1960), but it appears to be a northern form here at the southern limits of its range. Stephen's record of south Devon as a locality appears to be incorrect, and the present records are probably the most southerly so far.

One other species, Aphrodite aculeata, occurred mainly in the eastern Channel, but also in Great West Bay. It has a wide geographical range, from Iceland and Greenland to the Mediterranean. Although not recorded off Plymouth in the dredge survey, it is taken regularly on the trawling grounds. Its occurrence therefore resembles that of Buccinum, being far more common in the central and eastern parts than in the west, but unlike that species it is not, apparently, near the limits of its range in this area.

\section{DEPTH DISTRIBUTION}

Certain species recorded in the dredge survey are restricted to rather shallow water, probably having a zone of maximum abundance between low-tide mark and $c a$. Io $\mathrm{m}$ depth. The occurrence of such species in the dredge-hauls is sporadic, as it was possible to sample such depths only in a few areas. Additional information from grab and shore collections indicates that a few of these, such as Callista chione and Tellina squalida, do have a distribution restricted to certain parts of the Channel, but there are others, probably occurring throughout the Channel, which appear to have a patchy or restricted distribution owing to the scarcity of samples at the right depths: these include Donax vittatus, Ensis siliqua and Spisula solida. The majority of species taken in the survey showed little or no evidence of depth restriction, within the depth-range of the samples.

Ursin (1960) discusses the phenomenon of 'submergence' and has shown that certain echinoderms inhabit greater depths in more northern latitudes, while to the south they may extend on to the shore on the Atlantic coasts of France and in south-west England. This is a special example of submergence, not, apparently, previously recorded (cf. Ekman, I953, for other types of submergence), and Ursin does not consider it to be primarily connected with temperature. 
The same trend is shown, to a lesser extent, in certain lamellibranchs living in the Channel. Various species typically occurring offshore at Plymouth are found at low water around Falmouth, the Scilly Isles and on the north Brittany coast. Several of these are near the northern end of their range, and it would appear that in these circumstances they only occur below lowtide mark (Table 8). There also seems to be a tendency for certain species to have an increased tolerance of wave-action in the Channel Islands and on the Brittany coast. For example, Donax vittatus occurs on the shore only in certain semi-sheltered areas (particularly Tor Bay) in south-west England, but in south Brittany is common on the fully wave-exposed shores on the west side of the Quiberon peninsula (Prenant, 1932, and my own observations). Similarly, Solen marginatus occurs in sheltered creeks and estuaries in south-west England, but in Jersey on wave-exposed beaches. A similar distribution has been noted for Ensis arcuatus and E. ensis (Holme, 1954). Such differences may be partly due to higher average temperatures in winter in these southwestern areas, which enable these species to burrow more actively to avoid wave disturbance; possibly the relative scarcity of frosts and near-zero temperatures is significant.

Another factor which may affect depth distribution is related to the distribution of water masses in the Channel. There is reason to believe that certain species restricted to western areas of the Channel inshore may penetrate far up-Channel in the deeper water offshore. Several examples have been noted of such species occurring at the deeper-water stations $(8 I-83)$ south of Rye Bay. Isotherms and isohalines tend to lie in chevron formation pointing upChannel (Fig. 2), and one may suspect that the boundaries of certain species assume the same pattern, since other factors of which the isotherms and isohalines are merely an indicator may be similarly distributed. Hence the occurrence of certain species in deeper water in the eastern Channel than in the west is not related to depth per se, but to the distribution of water masses.

\section{NOTE ON ABRA PRISMATICA}

Ford (1923) described $A$. prismatica as a characteristic species of deeperwater (i.e. over $c a .40 \mathrm{~m}$ ) communities in silty sand off Plymouth, but he also recorded it from Bigbury Bay in 10-20 m. Although quite common in deeper parts of the Channel, this species is by no means confined to these depths, and occurs for example at several stations at about $\mathrm{Io} \mathrm{m}$ in Rye Bay. Its distribution in the dredge survey was sporadic, and may be connected with the avoidance of low salinities or high turbidity near the mouths of larger rivers. Wherever it occurred close inshore it was always at some distance from appreciable freshwater inflow. These observations support those of Jones (I956) in Manx waters. 


\section{SPECIES ABSENT OR RARE IN THE SURVEY}

Many species known to occur off the north Brittany coast do not normally range northward to the English coast. Some occur quite commonly at Roscoff, but are usually doubtfully included in the British fauna. Among burrowing species are:

\section{Divaricella divaricata \\ Donax variegatus \\ D. trunculus (not at Roscoff, but occurs in west Brittany) Mactra glauca \\ Leptosynapta galliennei \\ Labidoplax thomsoni (not at Roscoff, but occurs in west Brittany) \\ Sipunculus nudus (rare in British waters; one at Station 127).}

All these species may be found at low-water mark on parts of the Brittany coasts.

Beside these are some other species worthy of note which were absent or rare in the dredge survey.

Pinna fragilis appears to have occurred regularly at one time off the south Cornish coast (Clark, 1906), particularly south of Dodman Point; off Plymouth and at Salcombe (Marine Biological Association, 1957). At present it appears to be extremely rare in the Channel, although several fresh halfgrown, empty paired valves have been trawled in 1960 off Plymouth. It is common off Penmarc'h on the south Brittany coast, and apparently ranges northward up the west coast of Britain to Shetland, and southward to the Mediterranean.

Astarte triangularis is so small that it may have passed through the $2 \cdot 2 \mathrm{~mm}$ sieve used in the survey, so that the absence of records may not be significant. It has apparently declined in numbers in the Eddystone shell-gravel in recent years (Plymouth Marine Fauna, 1957), and this, coupled with its predominantly western distribution in British waters (Forbes \& Hanley, I853; Jeffreys, I862-69) suggests that it may be another Western species. It is distributed from Britain to the Mediterranean.

Pharus legumen has a curious distribution. It is a southern species, ranging from the Mediterranean to the west coast of Britain (Yonge, 1959), burrowing in sand at low tide and in shallow water. Although known from off the north coasts of Devon and Cornwall, in Wales and on the Brittany coasts, it is virtually absent from the English Channel coast. It is common on certain beaches near Roscoff (Station Biologique de Roscoff, 195I), but is not listed farther east from the Bay of S. Malo (Dautzenberg \& Durouchoux, 1913-I4), nor does it appear to occur in the Channel Islands. The few records from the south coast of England (e.g. Forbes \& Hanley, I853) must rank as exotics. I have not seen a single valve on any beach in south Devon or south Cornwall. There is no evidence of any alteration in the range of this species. 
TABLE 8. OCCURRENCE OF SPECIES AT LOW-TIDE MARK ON THE SHORE, SHOWING 'SUBMERGENCE'

C, common; Occ., occasional; R, rare; V.R., very rare.

Chlamys varia
Dosinia exoleta
D. lupinus
Callista chione
Venus verrucosa
Venerupis aurea
Tellina squalida
Thracia phaseolina
Pandora albida

Roscoff
C.
C.
Occ.
Occ.
Occ.
C.
Occ.
Occ.
Occ.

Bay of

Scilly

Falmouth Plymouth

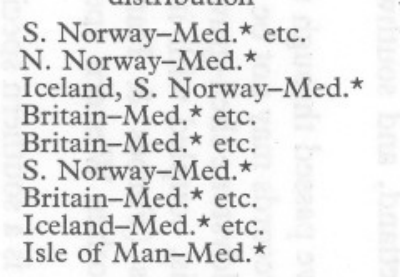

* Recorded by Bucquoy et al. (1882-98) from the Gulf of Lions.

\begin{tabular}{llcc} 
C. & R. & V.R. & - \\
C. & Occ. & V.R. & $\overline{-}$ \\
Occ. & R. & R. & V.R. ? \\
Occ. & $\overline{-}$ & - & - \\
R. & Occ. & V.R. & - \\
C. & - & $\overline{-}$ & - \\
Occ. & $\overline{-}$ & V.R. & - \\
Occ. & V.R. & R. & V. \\
\hline & V.R. & - & V.R. ?
\end{tabular}

\section{TABLE 9. DISTRIBUTION IN CHANNEL OF THREE} SELECTED GROUPS

\begin{tabular}{|c|c|c|c|c|c|c|}
\hline \multirow[b]{2}{*}{ Areas } & \multicolumn{2}{|c|}{ Lamellibranchia } & \multicolumn{2}{|c|}{ Gastropoda } & \multicolumn{2}{|c|}{ Echinodermata } \\
\hline & No. & $\%$ & No. & $\%$ & No. & $\%$ \\
\hline A only & I3 & I8. I & - & - & IO & $38 \cdot 5$ \\
\hline B only & 6 & $8 \cdot 3$ & 2 & $14 \cdot 3$ & - & - \\
\hline C only & 6 & $8 \cdot 3$ & - & - & - & $\bar{a}$ \\
\hline$A+B$ & II & $15 \cdot 3$ & 2 & $14 \cdot 3$ & 7 & $26 \cdot 9$ \\
\hline$A+C$ & 3 & $4 \cdot 2$ & - & - & 2 & $7 \cdot 7$ \\
\hline $\begin{array}{l}B+C \\
A+B+C\end{array}$ & $\begin{array}{r}7 \\
26\end{array}$ & $\begin{array}{r}9 \cdot 7 \\
36 \cdot 0\end{array}$ & $\begin{array}{l}5 \\
5\end{array}$ & $\begin{array}{l}35 \cdot 7 \\
35 \cdot 7\end{array}$ & $\overline{7}$ & $\overline{26.9}$ \\
\hline Total species & 72 & 99.9 & $\begin{array}{r}5 \\
14\end{array}$ & 100.0 & 26 & $100 \cdot 0$ \\
\hline
\end{tabular}

Total species in each area, and percentage of total in Channel

$\begin{array}{rrrrrrr}\text { A } & 53 & 73 \cdot 6 & 7 & 50 & 26 & 100 \\ \text { B } & 50 & 69 \cdot 4 & 14 & 100 & 14 & 53.8 \\ \text { C } & 42 & 58 \cdot 3 & 10 & 71 \cdot 4 & 9 & 34.6\end{array}$




\section{SOME ASPECTS OF DISTRIBUTION}

Table 9 shows the distribution of the three main groups in different areas of the Channel. For this purpose the Channel was divided into three areas, approximately corresponding to the Meteorological Office weather forecasting sea areas (Fig. 4):

(A) Plymouth: Mount's Bay to Start Point (45 stations).

(B) Portland: Start Point to St Alban's Head (46 stations).

(C) Eastern area, Wight plus Dover: St Alban's Head to Straits of Dover (76 stations).

In the lamellibranchs there is no great decrease in numbers of species on passing up-Channel. Although several species are restricted to Plymouth, the total is maintained in Portland by the presence of additional species of the Sarnian group, which are also present in the Eastern area. Among the gastropods, none is restricted to Plymouth, and only two species to the western half of the Channel. Sarnian species in areas B and C swell the numbers in these areas, so that the Plymouth area is the poorest in numbers of species. The reverse trend is seen in the echinoderms, in which $65.4 \%$ of the total species are restricted to the western half of the Channel, and all the recorded species occur in Plymouth. The Sarnian type of distribution is not represented, and there is consequently a considerable fall in numbers of species in the Eastern area. The occurrence of a few species of lamellibranchs and echinoderms in areas $\mathrm{A}$ and $\mathrm{C}$ but not in $\mathrm{B}$ is not considered significant, as it is probably due to sediment requirements.

This analysis indicates the relative suitability of different groups as indicators of conditions in the Channel area. The lamellibranchs are considered the most suitable for the following reasons.

(a) They are the most abundant in terms of numbers of individuals and species, and they occur at a higher proportion of stations than any other group.

(b) They show a better balance of population trends, as outlined above, than do the gastropods or echinoderms.

(c) Additional evidence provided by dead mollusc shells is of value in certain circumstances.

These remarks apply only to the Channel area and to the scale of sampling employed. However, they accord with the views of Stephen (1934) who considered that 'the molluscs should be chosen as the main group for dividing off the natural areas in, at any rate, the North Sea, and that the echinoderms may be used for making further subdivisions, if desired'.

For a quantitative study of total populations the Channel was divided into fourteen areas, from west to east, each containing ten stations (see Fig. 4 and Appendix). A few stations were eliminated to make the areas comparable. 
Total numbers of species in each area are shown in Fig. 12; these show the same general trends noted above.

Totals of individuals are shown in Figs. I3 and I4. The lamellibranchs show three distinct peaks, corresponding to areas 2 (Falmouth Bay), 8 (eastern part of Great West Bay and Weymouth Bay) and I4 (Rye Bay), and similar

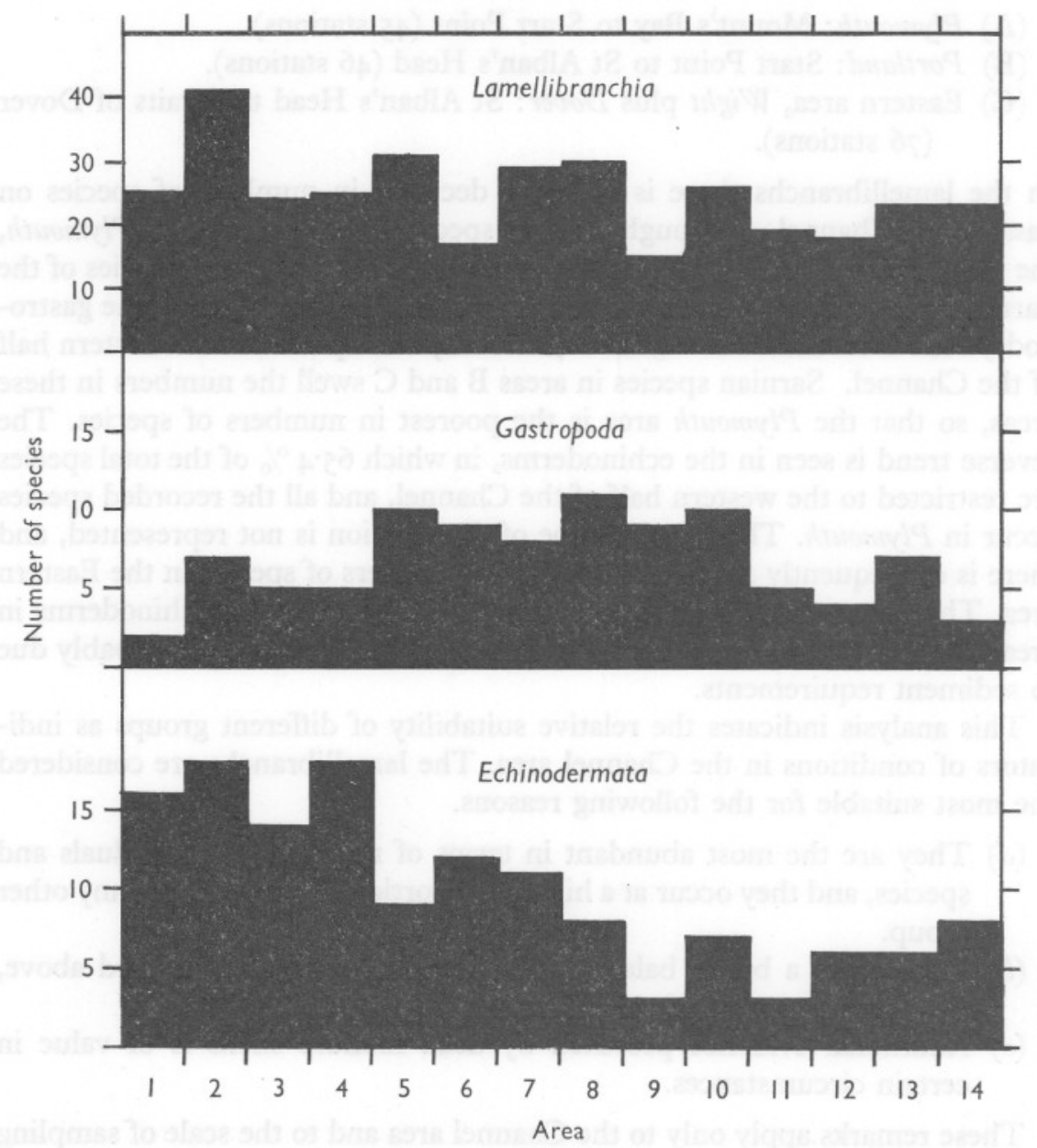

Fig. 12. Numbers of species recorded per ten stations in each area of the Channel. Areas are shown in Fig. 4: the areas run from west to east, area I being Mount's Bay.

peaks may be discerned, but not in precisely the same areas, in the gastropods and echinoderms. Areas 3 and 4 , lying respectively west and east of Plymouth, are the poorest in numbers of lamellibranchs and are not very rich in gastropods and echinoderms. 


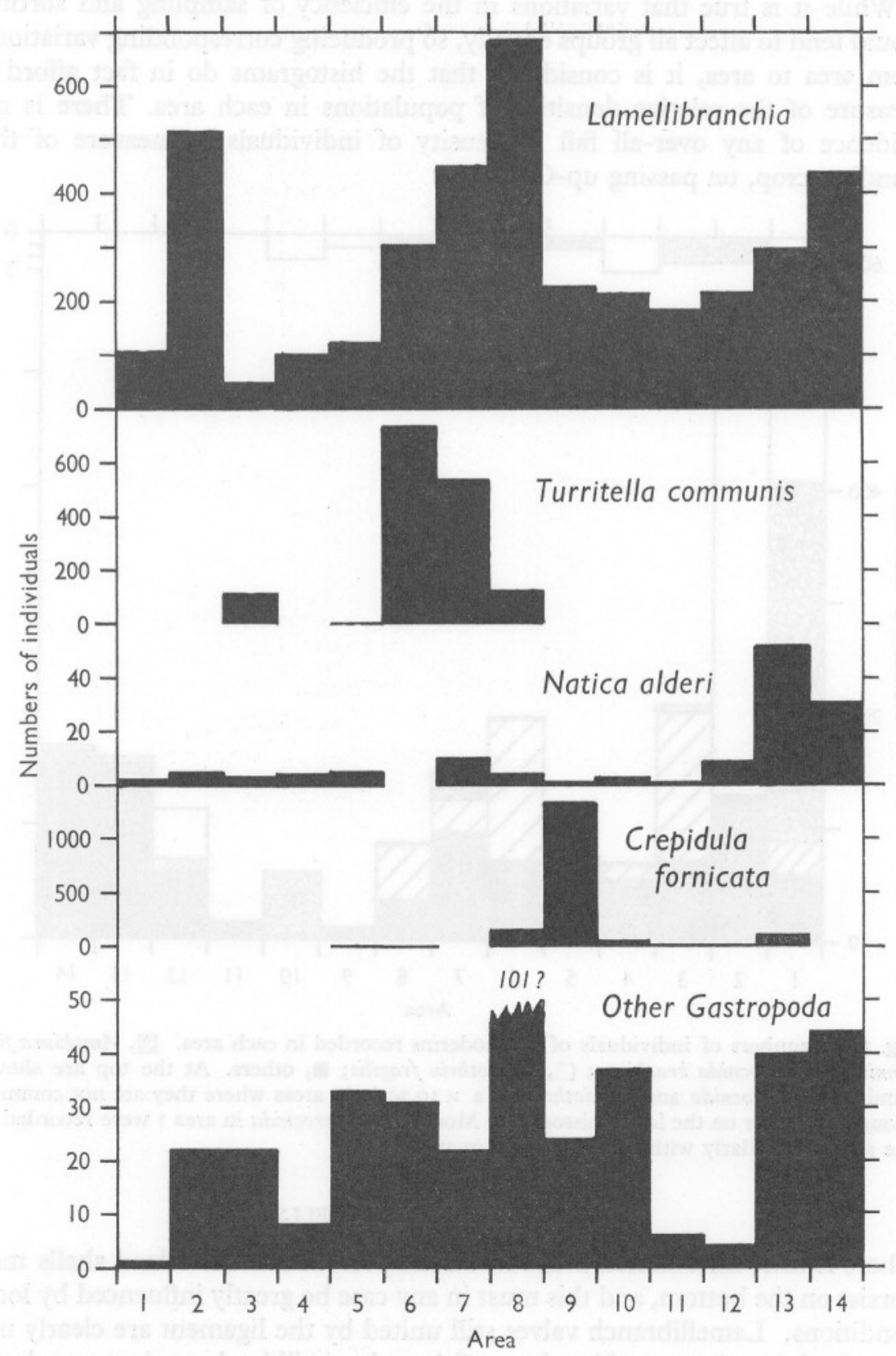

Fig. 13. Numbers of individuals of lamellibranchs and gastropods recorded in each area. 
While it is true that variations in the efficiency of sampling and sorting would tend to affect all groups equally, so producing corresponding variations from area to area, it is considered that the histograms do in fact afford a measure of the relative densities of populations in each area. There is no evidence of any over-all fall in density of individuals, a measure of the standing-crop, on passing up-Channel.

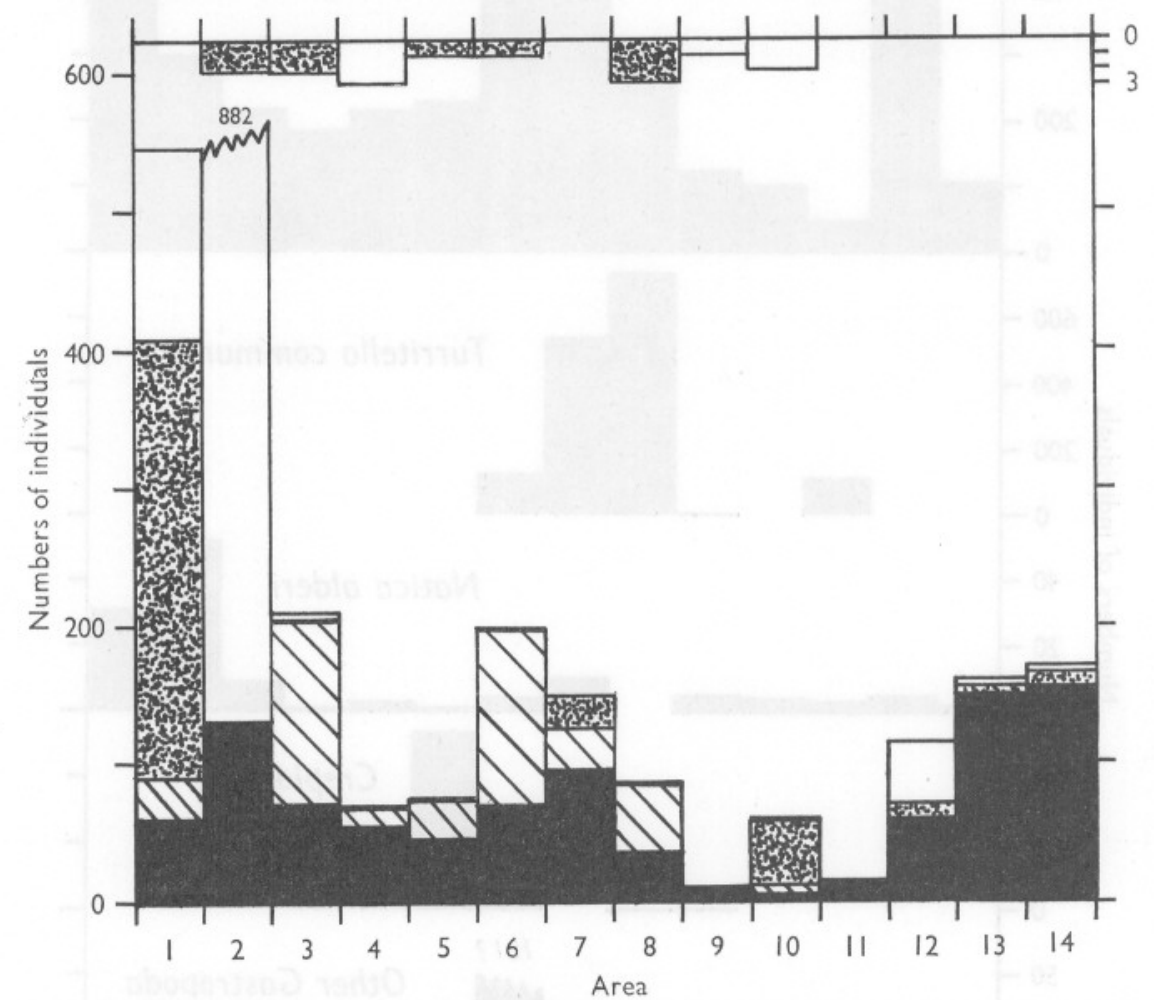

Fig. I4. Numbers of individuals of echinoderms recorded in each area. $\mathbb{Q}$, Amphiura filiformis; 泪, Acrocnida brachiata; $\square$, Ophiothrix fragilis; $\mathbf{0}$, others. At the top are shown numbers of Acrocnida and Ophiothrix on a $\times$ IO scale in areas where they are not common enough to appear on the lower histogram. Most of the Acrocnida in area I were recorded at one station, similarly with the Ophiothrix in area 2.

\section{EVIDENCE FROM DEAD SHELLS}

There is little information available on the period for which dead shells may persist on the bottom, and this must in any case be greatly influenced by local conditions. Lamellibranch valves still united by the ligament are clearly not long dead, but the rate of break-up of the valves will be dependent mainly on whether they remain buried in the sediment or lie on the surface, soon to be broken up by current or wave disturbance. There are clearly great differences 
in the fragility of shells; some delicate forms such as Mactra corallina, Thyasira or Thracia must persist for a much shorter time than thick-shelled species such as Nucula, Arca or Glycymeris. Birkett ${ }^{1}$ has estimated the survival time of intact valves of Mactra on the Dogger Bank, from which he has evolved a 'half-life' formula giving the rate of break-up of species of different shell thickness. Apart from radiocarbon or similar dating methods, however, there is no method of telling the age of the individual shells found in a deposit. Since there is little or no net deposition of sediment in the Channel the depth in the deposit at which a shell is found probably has little bearing on its age.

While it is fairly certain that dead shells can remain buried in situ almost indefinitely, if transported along the bottom the chances of being broken up are greatly increased so that one might expect a limit to the distance which they can be transported, based on the thickness, size and strength of the shell.

Evidence from dead shell remains in the Channel is fairly consistent with the present and presumed past distribution of the mollusc fauna. The virtual absence of dead shell records of West Channel species east of St Alban's Head, both living and dead shells of the commoner species reaching about the same limits, indicates at least no general transport of sediments in an easterly direction. It does not rule out, however, the possibility of movement in a westerly direction. Since the chances are that at least a proportion of the shells would remain in situ in the sediment in which they lived, it is probably safe to say that the boundary of West Channel species has never been farther east than it is at present.

With the Western species there is evidence from dead shells that some occurred in the past in the south-west corner of Great West Bay. It seems unlikely that these would have been transported any appreciable distance without breaking up, and since the evidence from West Channel species is against a movement of shells in an easterly direction, it seems fairly certain that at some time in the past 'western' influences reached as far as this part of Great West Bay.

For the other types of distribution the limits are less definite, and a few dead shells are often recorded beyond the areas in which living specimens were taken. In most instances this probably results from a gradual falling-off in population density and not from any change in distribution. Since dead shells often outnumber living specimens by a hundred or even a thousand to one it may be expected that they would be found over a wider area than the records of living specimens.

Apart from a few fossil shells, no evidence of past faunas significantly different from those of today has emerged.

\footnotetext{
1 I.C.E.S. report, 1960 meeting.
} 


\section{DISCUSSION}

\section{THE ACTION OF LIMITING FACTORS ON BENTHIC ORGANISMS}

Temperature is naturally an important factor controlling geographical distribution. At the northern end of their range species may be dependent on high summer temperatures to enable spawning to take place (Orton, 1920), and sufficiently low winter temperatures may be required by species near the southern limits of their range. Crisp \& Southward (1958) consider that a certain level of temperature through the year may be important for some intertidal species, but to what extent this is ever a critical limiting factor is questionable. Abnormally low winter temperatures, above freezing-point, are sometimes lethal (e.g. Ursin, 1960), and it is possible that certain (Cornubian) species may be intolerant of the lower minimum temperatures in the more eastern parts of the Channel.

Turbidity may be a limiting factor in certain circumstances. The lamellibranchs, with which this paper is mainly concerned, are either deposit or suspension feeders, and in filtering off food particles may at times have to reject large quantities of inorganic material. Suspension feeders draw in water from only a few millimetres off the bottom, so that their food is qualitatively rather similar to that obtained by deposit feeders which draw in material from the surface of the sediment. Under disturbed conditions the material drawn in by these two methods of feeding must be almost identical. Large quantities of inorganic silt or clay in suspension depress the filtering rates of certain lamellibranchs (Loosanoff \& Tommers, I948; Rice \& Smith, I958), and adversely affect the development and growth of certain larvae (Davis, 1960). The high concentrations of silt and clay used by these workers would, however, only be attained in harbours and estuaries; they are probably much higher even than in water close to the bottom in open sea areas such as the Channel. Pratt (1953) showed experimentally that populations of Venus mercenaria, a suspension feeder, grew $24 \%$ faster in sand than in an adjacent plot of sandy mud containing much organic matter. On the whole one may expect high concentrations of silt and clay to affect suspension feeders more adversely than deposit feeders, since the latter are normally accustomed to sort their food from deposits containing a high proportion of non-edible material.

Shelter from excessive bottom-disturbance is a condition of survival for many forms. The densest populations usually occur in the more sheltered areas, but in assessing the effect of wave or current disturbance both bottom contour and depth must be taken into account. In general the western end of the Channel is more scoured by waves and the more eastern areas by tidal currents. Rich populations occur in bays, not only because of the shelter they provide but also because of the presence of eddies which appear to favour the 
settlement of larvae (Orton, 1937) and the deposition of food in the form of detritus.

Many common benthos species appear to be tolerant, within limits, of a fairly wide range of sediment grades (e.g. Davis, 1925)—otherwise they would not be so generally distributed. Subtle physico-chemical or biological factors such as were found by Wilson (1958) to affect the settlement of Ophelia larvae could scarcely be necessary for the settlement of species apparently more catholic in their choice of bottom.

On the other hand, Wilson \& Armstrong's (1958) experiments on the viability of certain larvae in different natural waters suggest the importance of as yet unknown factors in sea water which may affect the development of certain species.

It is very difficult to assess the relative importance of the different factors, as outlined above, in controlling the distribution of species. Certain factors (such as salinity in the Channel) appear not to vary sufficiently to be important, but the possibilities of the interaction of two or more such factors cannot be overlooked. It is in fact easy to say that a certain distribution is not apparently correlated with one particular factor, but where, as is generally the case, so many factors may be interacting, one can do no more than suggest possible or probable causes.

\section{NATURE OF THE FAUNISTIC BOUNDARIES}

Faunistic boundaries in the Channel appear to fall into two categories: the rigid boundaries to the Western and West Channel species, beyond which living specimens or dead shells are seldom taken, and the more indefinite boundaries shown by a gradual decline as species approach the limits of their distribution. The principal distribution patterns in the Channel are summarized in Fig. I5.

In discussing faunistic boundaries the question arises as to whether the populations occurring near their limits of distribution are self-maintaining, or whether they are a collection of non-breeding individuals recruited by larval drift (or even by migration of adults) from areas more favourable to reproduction of the species. Little information is available on this point, the most pertinent data being those of W. J. Rees (I950) and Rees \& Lumby (1954) which indicate that populations of Octopus vulgaris on the south coast of England are mainly derived from larvae drifted across the Channel from the Channel IslandsS. Malo region, the octopus only breeding in English waters in certain years. The larval life of the octopus is fairly long, however, estimated at 2 months, which is probably rather longer than that of the majority of pelagic larvae. For the invertebrates studied in the dredge survey, particularly the critical Western species, however, information on breeding seasons, the existence of larvae and the duration of larval life are insufficient to assess the possible importance of larval drift (Thorson, I946; C. B. Rees, I951, I954). 

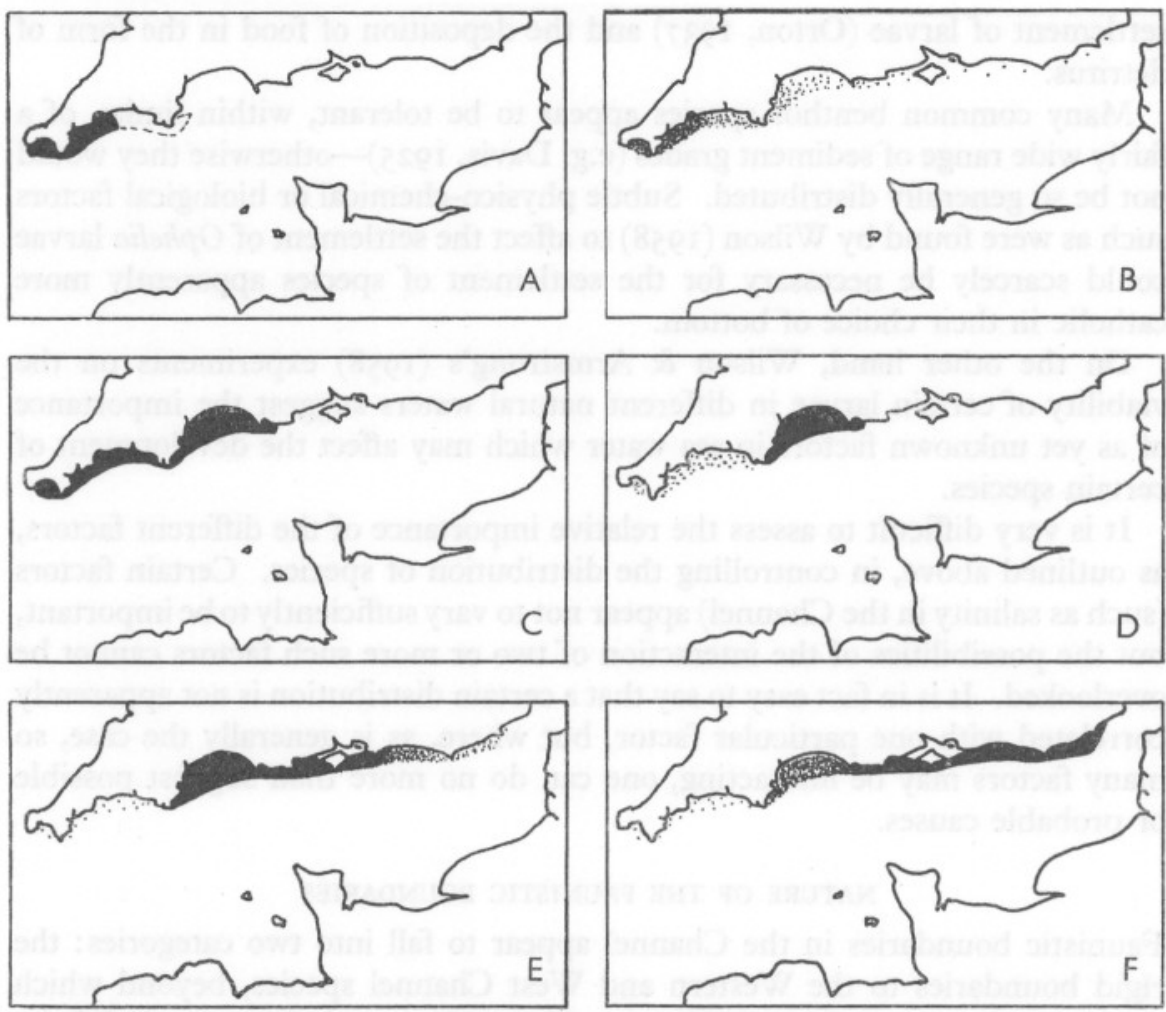

Fig. 15. Distribution patterns on the English side of the Channel. A. Western species. The pecked line shows the maximum penetration into the Channel at any time as shown by dead shell records, the black area the present distribution. B. Cornubian species. c. West Channel species. D. West Channel species mainly confined to Great West Bay (possibly a combination of distributions shown in C and E). E. Sarnian species. F. Northern species. Occurrences outside the area covered by the survey are not shown.

\section{Western species}

Western species are at present restricted, in inshore waters, to the Cornish coast west of about Looe. There is today no apparent correlation with the distribution of Sagitta elegans nor with any other plankton indicator (A. J. Southward, personal communications), although there is some evidence that the occurrence of Western forms at Plymouth in the 1920's and also in the northwest North Sea is in some way connected with water of the elegans type. In 1922-23 the typically Western species Myrtea spinifera, Gafrarium minimum, Tellina pygmaea, Gari tellinella and Thracia villosiuscula were quite common in the Plymouth area, more so than anywhere off the south Cornish coast today, and Tellina pygmaea and Gari tellinella were common and Myrtea and Thracia occasional in Plymouth Sound. The farthest east limit at any time, as shown by dead shell records, appears to be the south-western part of Great West Bay. Hunt (1884) records Gari tellinella as common, living, off Tor Bay, 
but there is no other evidence of when this maximum up-Channel penetration. occurred.

The temperature régime off the north-east coast of Scotland, where some Western species occur, is several degrees lower than off Plymouth. The German charts (Deutschen Seewarte Hamburg, I927) show February bottom temperatures off Scotland in the region of $5-7^{\circ} \mathrm{C}$, contrasted with $8-9^{\circ} \mathrm{C}$ in inshore waters off Plymouth. In August the bottom temperature is $\mathrm{IO}^{\circ}-\mathrm{II}^{\circ} \mathrm{C}$ off Scotland and about $13^{\circ} \mathrm{C}$ off Plymouth. Temperatures off the Scottish coast in February are comparable with those in the Straits of Dover in the same month, and in August are about $2^{\circ} \mathrm{C}$ cooler than anywhere in the Channel. These figures were compiled over 30 years ago, and February and August figures do not necessarily represent minimum and maximum values, but they are sufficient to show the very big differences between the two areas. On the basis of these figures the only value which might be responsible for the restriction of Western species to western areas of the Channel would be that maximum temperatures in the central and eastern areas of the Channel are too high. The slight increase in sea temperatures which has occurred in recent years would then be seen as the cause of the westward shift of their boundary since the I920's. All five species range as far south as the Mediterranean, however, so this seems an unlikely explanation. The annual range of temperature off Plymouth and off Scotland is comparable, of the order of $5^{\circ} \mathrm{C}$, which suggests that these might be relatively stenothermal species intolerant of the higher annual ranges in the central North Sea and English Channel. The occurrence of some Western forms in Plymouth Sound, inside the breakwater, in the I920's appears to be critical. Conditions in Plymouth Sound tend to be estuarine, and sufficient vertical mixing probably occurs (although few data are available) for the annual range in temperature and salinity to be at least as great as in open waters in the more central and eastern parts of the Channel. This tends to discount the possibility that the species are sufficiently stenothermal (or stenohaline) for this to be a limiting factor in offshore waters of the Channel. Similar reasoning discounts the possibilities of sewage or other urban pollution, or turbidity, as limiting factors in the Channel. Pollution with kaolin and mica fragments from china clay workings occurs both in Plymouth Sound and St Austell Bay. Both Myrtea and Gari tellinella occur in St Austell Bay today, and were common in the Sound in the I920's, so this source of pollution appears to be unimportant.

It seems quite possible that the present distribution represents the normal and that of 1922-23 the exceptional. Clark (1906) gives the following records for Cornwall:

Lucina (= Myrtea) spinifera. Dead shells not uncommon, Plymouth district, but only one live specimen on Rame-Eddystone grounds (M.B.A.). Not uncommon in trawl refuse and in 20- to 30 -fathom dredgings from Falmouth Bay; Mount's Bay; St Mary's Sound, Scilly.

Tellina pusilla (= pygmaea). Not recorded east of Fowey. (Fowey is at the eastern end of St Austell Bay). 
The apparently abrupt nature of the boundary both in the English Channel and North Sea suggests the action of an injurious factor acting at some stage earlier than at maturity of the adult. A factor which merely prevented reproduction would tend to give a more indefinite boundary, owing to larval drift, as in the case of the octopus. That larvae do drift beyond the area occupied by adults is suggested by C. B. Rees (I95I, I954), who recorded on several occasions in autumn larvae believed to be of Myrtea spinifera in the central North Sea. If this is the normal state of affairs it suggests that limiting factors operate either just before, during or just after metamorphosis. As to the nature of this limiting factor one can only point to the possibility that some trace substance or 'metabolite' is responsible.

\section{West Channel species}

West Channel species also have a fairly rigid eastern boundary which suggests that larval drift may not be a significant factor in distribution. The number of records of dead shells in inshore waters east of St Alban's Head is negligible, suggesting that the boundary is fixed in position, and since it lies near the geographical division between the western and eastern halves of the Channel it is likely that it is in some way connected with the abrupt change in the width and character of the Channel east of a line from Portland Bill to Cap de la Hague. The unfavourable nature of the grounds in Poole Bay for certain species and the 'rough' tide-swept bottom south of the Isle of Wight may tend to over-emphasize the sharpness of the faunistic boundary, but it is significant that it occurs for so many species, with such a variety of sediment preferences, at about the same point. Of the species confined to the western half of the Channel, a few are at the northern end of their range, and these have been included in the Cornubian group. The majority of West Channel species range well north and south of the British Isles, and it seems unlikely that temperature limits them to the western Channel. The majority of the lamellibranchs are suspension feeders, which suggests that the increased turbidity in the eastern Channel, due to stronger tidal streams and rather shallower water, may partly account for their absence. Many West Channel species are, however, generally distributed in the North Sea, and Venus striatula, a species absent from the eastern Channel, is common off the Dutch coast where the bottom fauna has the following characteristics (Kristensen, 1959): 'they all thrive on rather fine as well as on rather coarse sand, they tolerate salinity fluctuations between at least 30 and $35 \%$, and they can stand the high summer temperatures of $17^{\circ} \mathrm{C}$ and the low winter temperatures of $2^{\circ} \mathrm{C}$ and even less.' Such an environment, evidently much more rigorous than in the eastern Channel, scarcely accounts for the absence of $V$. striatula in the latter area. Another West Channel species, Dosinia exoleta, also occurs, in lesser numbers, off the Dutch coast.

Turbidity may be the limiting factor in the eastern Channel, but it is 
difficult to believe that this could affect the adults of species burrowing in muddy deposits, such as Turritella and Amphiura filiformis. Such species must at times have to survive in water which is very turbid near the bottom, whatever the condition of the overlying water mass. The eastern end of the Channel, particularly Rye Bay, supports a rich fauna of sand and muddy-sand dwellers, including a number of suspension-feeding lamellibranchs. Much more information is required on the degree of turbidity of waters in the immediate neighbourhood of the bottom and the ability of suspension feeders to withstand such conditions before we can fully assess the importance of this factor.

Both the Western and West Channel echinoderms seem to penetrate slightly farther east than the lamellibranchs. Ophiocomina nigra occurs at least as far east as Plymouth Sound (Marine Biological Association, 1957), and there are isolated records of other possibly western species (e.g. Amphiura chiajei, Amphiura securigera, Pseudocucumis mixta) up to Bigbury Bay. Similarly, Amphiura filiformis crosses the east/west Channel boundary, the last records being in Poole Bay. Information on the echinoderms is so much less complete than on the molluscs that one can do no more than remark on this apparent anomaly.

At this point a comparison with Crisp \& Southward's (1958) conclusions on the shore fauna may be of value. They found that a number of species were limited on the English side to the coastline west of the Isle of Wight, and that the majority of these were southern species with northern limits in the British Isles. Of the species ranging well to the north of the British Isles, the majority were found in similar abundance in both halves of the Channel. This is almost the reverse of the situation with the offshore fauna, in which the majority of southern species (the Sarnian group) occurred in both halves of the Channel, and the species restricted to the western Channel were in the main not near their northern limits. For this reason I am less inclined to view temperature as an important limiting factor than were Crisp \& Southward for the intertidal fauna.

\section{Cornubian species}

The numbers of Cornubian species are small, and their distributional boundaries indistinct. They are all southern species spreading into the Channel from the west, and their typical habitat is off the south Cornish coast, their numbers decreasing fairly rapidly on passing up-Channel. Absence of low winter temperatures may be a limiting factor, but as many occur at L.W.S.T. as well as offshore in Cornwall they are probably not highly stenothermal. The boundaries limiting the Western and West Channel groups may affect these species also, but to a less marked extent. Thus Tellina squalida becomes less common offshore and very rare on the shore from about Plymouth eastward. Hepper (1957) found that the southern species Mytilus galloprovincialis reached its eastern limit in the Channel at about Plymouth, and 
this may be due to a change in the character of the water masses affecting a species already nearing its limits of temperature tolerance. Other Cornubian species range farther east, Labidoplax digitata extending nearly to Portland, and its final limits may be at the east/west Channel boundary.

\section{Sarnian species}

The Sarnian species are all southern forms nearing their northern limits in the English Channel. As with the Cornubian species their extreme limits are rather indefinite, and they may extend into the North Sea along the Belgian and Dutch coasts and also into Scandinavia. On the English side of the Channel Sarnian forms occur mainly in the central regions, their presence depending probably on sufficiently high summer temperatures to enable spawning to occur, and they also seem to be tolerant of the lower winter temperatures in the same areas. Successive stages in a possible northward spread of southern forms into the Channel may be traced from a study of the present distribution of southern species from the Bay of Biscay northward. The most southerly forms are restricted to the South Brittany coasts, occurring in such areas as Quiberon Bay, and farther north in Douarnenez Bay (Prenant, 1932, 1939, and my own observations). Examples are Donax trunculus and Labidoplax thomsoni. To the north the north-western corner of Finistère is surrounded by water which reaches only about $15^{\circ} \mathrm{C}$ at the surface in summer (Lumby, I935; Crisp \& Fischer-Piette, 1959), and which may therefore act as a partial barrier to further extension of shallow-water forms into the Channel. The Channel Islands-S. Malo region is warmer in summer than farther west, and species which reach their limit in this area may be commoner than at Roscoff in north-west Brittany. An example is the ormer, Haliotis tuberculata, which does not occur in Britain. The next stage is represented by Octopus vulgaris which breeds on the south side of the Channel, and is represented by a normally non-breeding population off the south coast of England. A stage further takes us to species like Dentalium vulgare and Nassarius pygmaeus, which are quite common in the central Channel on the English side, and may well form a self-supporting population, although there is no evidence on this point. West of Start Point they become very rare, perhaps because of lower summer temperatures. Venus verrucosa, most abundant in the central region, occurs both at low tide and offshore west of Start Point (e.g. Plymouth Marine Fauna, I957; Clark, I906), but is never particularly common there. It represents a further stage in colonization of the English coast, the final stage being shown by Venerupis rhomboides, a southern form common throughout the length of the Channel.

This series is hypothetical, since we know little of the limiting factors for individual species, and indeed the observations of Rees and Lumby (1954) failed to show a clear correlation between the breeding of Octopus vulgaris and sea temperature, but it suggests the most probable route for colonization 
of the Channel by many southern forms. Two successive barriers to such a northward spread exist: the first the cooler summer temperature off the tip of Finistère, the second the deep and probably rather barren area between the Channel Islands and the south coast of England. To what extent these barriers can be regularly bridged by larval drift is uncertain.

\section{Northern species}

This last group includes only a few species. One northern species, Chlamys tigerina, appears to be restricted to the western end of the Channel, but the other northern species, Spisula elliptica, Buccinum undatum and Maxmulleria lankesteri show a decidedly eastern trend. Buccinum spawns in winter and early spring at Plymouth, as one would expect of a species at the southern end of its range. The distribution of Buccinum both in the Channel and in respect to its southern limits in the Bay of Biscay is rather similar to that of Balanus balanoides (Crisp \& Southward, 1958; Crisp \& Fischer-Piette, 1959).

The tendency for both Spisula and Buccinum to occur in much greater numbers in the central and eastern parts of the Channel may well be related to the lower winter temperatures in these areas.

Criticism of this paper will no doubt be levelled at the often-deplored attempt to group species into ecological categories. This has only been possible by ignoring the more detailed distribution of species, no doubt largely due to specific preferences for sediments of a particular grade, and at the same time assuming that a sufficient range of types of sediment occurs in each area to provide a suitable habitat for the commoner species. In this way an attempt has been made to use species as indicators of hydrographical conditions. It is at once clear that being fixed in the adult stage, their distribution has a different order of significance compared with plankton indicators. There are some indications that the distribution of some groups is not so much connected with the dispersal of pelagic larvae, but with the conditions of life experienced either at metamorphosis or in the early bottom stages. Thus they may well serve as more permanent indicators of the hydrographic conditions in particular areas, and so supplement the information derived from plankton indicators.

\section{SUMMARY}

A survey has been made of the bottom fauna in ca. I0-50 $\mathrm{m}$ along the south coast of England, using a modified anchor-dredge. Particular attention has been paid to the molluscs (both living and dead) and to the echinoderms, only larger or more conspicuous members of other groups being identified.

Within the Channel there are considerable variations in temperature and other hydrographic conditions, and these are discussed in relation to their possible role as limiting factors in distribution. The fauna and bottom deposits of the different areas covered in the survey are briefly described. 
Distribution trends are classified as:

(I) Species generally distributed in the Channel. This is the largest group, and includes three species reaching their northern limits in British waters.

(2) Species confined to the western parts of the Channel.

(a) Western species. Four or five species common at Plymouth in the I920's, but now absent or very rare. Small numbers are found today only off the south Cornish coast, and those which occur in the North Sea are restricted to the north-western areas. Apart from one species, these forms are not at their geographical limits in the English Channel, and their occurrence may be partly related to the presence of 'western', but not necessarily Sagitta elegans, water.

(b) Cornubian species. These are near the northern end of their range, and occur quite commonly off the south Cornish coast, becoming progressively less common farther up-Channel. It is suggested that their distribution is related to an intolerance of the lower winter temperatures in the more eastern part of the Channel.

(c) West Channel species. These are generally distributed in the western half of the Channel, but suddenly disappear on entering the eastern Channel. This group comprises many species generally distributed and common in British and northern European waters. Since the majority are not near their geographical limits, temperature is discounted as a limiting factor, and a possible explanation of their disappearance is the greater turbidity of waters in the eastern Channel.

(3) Species distributed around the central region of the Channel. This includes a number of species at the northern end of their range which are common in the Channel Islands-S. Malo area, and are therefore referred to as Sarnian forms. Although commonest in the central Channel, many are present, in smaller numbers, along the Devon and Cornish coasts west of Start Point. Their abundance in the central region may be due to the higher summer temperatures in this area, while at the same time they appear to be tolerant of the relatively low winter temperature in the same places.

(4) Northern species, most common in the eastern Channel, gradually decreasing in numbers farther west. Probably dependent on low winter temperatures.

Distributional boundaries are of two kinds: the rather gradual boundaries to the Cornubian, Sarnian, and Northern species, which are believed to be due to temperature; and the abrupt boundaries of the Western and West Channel species ascribed to as yet unknown hydrographic factors.

A special type of 'submergence', similar to that described by Ursin for echinoderms, is described in relation to lamellibranch faunas in the Channel.

An analysis of the distribution of different phyla and classes has been made. The lamellibranchs show a fair balance between the trends outlined above, the gastropods do not contain any species in the Western group but are 
represented by a number of Sarnian forms, so that there are more species in the central Channel than in western areas. The echinoderms have a predominantly western distribution, in a general sense, and numbers of species show a decline on passing up-Channel.

Total populations of individuals in different areas of the Channel are considered. The richest areas are around Falmouth (also the richest in numbers of species), around Portland and in Rye Bay. The total in each of these areas is much the same, so that there is no evidence that the eastern Channel is any poorer in terms of the 'standing-crop' than the more western areas.

The role of dead shells as evidence of present and past populations is briefly considered. There is no evidence that dead shells are transported any appreciable distance from the areas in which they originally lived.

Possible limiting factors are discussed. Temperature, turbidity, shelter from bottom-disturbance, and the effects of different sediments on distribution are considered, and the difficulties in assigning any single factor as causative are stressed.

The possible causes of the different distributional trends are discussed, with special reference to the Western, West Channel and Sarnian species. A number of possible factors are discounted, but the causes of the limited distribution of these two groups remain obscure.

The Appendix contains a note on the identity of specimens of Spisula used by the late Dr D. Atkins in her work on ciliary mechanisms.

\section{REFERENCES}

AlleN, E. J., I899. On the fauna and bottom deposits near the thirty-fathom line from the Eddystone to Start Point. F. mar. biol. Ass. U.K., Vol. 5, pp. 365-542.

Allen, J. A., I954a. A comparative study of the British species of Nucula and Nuculana. F. mar. biol. Ass. U.K., Vol. 33, pp. 457-72.

I954b. On the structure and adaptations of Pandora inaequivalvis and P. pinna. Quart. F. micr. Sci., Vol. 95, pp. 473-82.

I $958 \mathrm{a}$. On the basic form and adaptations to habitat in the Lucinacea (Eulamellibranchia). Phil. Trans., B, Vol. 24I, pp. 42I-48.

I 1958 . Observations on Cochlodesma praetenue (Pulteney) (Eulamellibranchia). F. mar. biol. Ass. U.K., Vol. 37, pp. 97-II2.

AtKINs, D., 1937. On the ciliary mechanisms and interrelationships of lamellibranchs. Part II. Sorting devices on the gills. Quart. F. micr. Sci., Vol. 79, pp. 339-73.

BIRKETT, L., I953. Change in the composition of the bottom fauna of the Dogger Bank area. Nature, Lond., Vol. I7I, p. 265.

BLACKER, R. W., 1957. Benthic animals as indicators of hydrographic conditions and climatic change in Svalbard waters. Fish. Invest., Lond., Ser. 2, Vol. 20, No. IO, $49 \mathrm{pp}$.

BouviER, E.-L., I940. Décapodes marcheurs. Faune Fr., T. 37, 404 pp.

Bucquoy, E., Dautzenberg, P. \& Dollfus, G.-F., 1882-98. Les Mollusques marins du Roussillon. T. I \& 2. Paris: Baillière and Sons.

Clark, J., 1906. Marine Zoology. Victoria Co. Hist.: Cornwall, pp. II3-60. 
Cole, H. A., 1952. The American slipper limpet (Crepidula fornicata L.) on Cornish oyster beds. Fish. Invest., Lond., Ser. 2, Vol. 17, No. 7, 13 pp.

COOPER, L. H. N., I960 $a$. The water flow into the English Channel from the southwest. F. mar. biol. Ass. U.K., Vol. 39, pp. 173-208.

- 1960 $b$. Exchanges of water between the English and Bristol Channels around Lands End. F. mar. biol. Ass. U.K., Vol. 39, pp. 637-58.

CrisP, D. J. \& FisCheR-PIETTE, E., I959. Répartition des principales espèces intercotidales de la côte Atlantique française en 1954-1955. Ann. Inst. océanogr. Monaco, T. 36, pp. 275-387.

CRISP, D. J. \& SouTHWARD, A. J., 1958. The distribution of intertidal organisms along the coasts of the English Channel. F. mar. biol. Ass. U.K., Vol. 37, pp. 157-208.

Danois, E. Le, 1948. Les Profondeurs de la Mer. Trente ans de recherches sur la Faune sous-marine au large des côtes de France. 303 pp. Paris: Payot.

Dautzenberg, Ph. \& Durouchoux, I913-I4. Les mollusques de la Baie de SaintMalo. Feuill. jeun. Nat., Suppl. Nos. 514-18; 520-2, 64 pp.

Davis, F. M., I923. Quantitative studies on the fauna of the sea bottom. No. I. Preliminary investigation of the Dogger Bank. Fish. Invest., Lond., Ser. 2, Vol. 6, No. 2, pp. I-54.

- 1925. Quantitative studies on the fauna of the sea bottom. No. 2. Results of the investigations in the southern North Sea, 1921-24. Fish. Invest., Lond., Ser. 2, Vol. 8, No. 4, pp. I-50.

Davis, H. C., I960. Effects of turbidity-producing materials in sea water on eggs and larvae of the clam (Venus (Mercenaria) mercenaria). Biol. Bull., Woods Hole, Vol. II 8, pp. 48-54.

Deutschen Seewarte Hamburg, 1927. Atlas für Temperatur, Salzgehalt und Dichte der Nordsee und Ostsee. Hamburg.

DIETRICH, G., I950. Die anomale Jahresschwankung des Wärmeinhalts im Englischen Kanal, ihre Ursachen und Auswirkungen. Dtsch. hydrogr. Z., Bd. 3, pp. 184201 .

Einarsson, H., I948. Echinoderma. Zool. Iceland, Vol. 4, part 70, 67 pp.

Ekman, S., 1953. Zoogeography of the Sea. 4I7 pp. London: Sidgwick and Jackson.

Elmhirst, R. \& STEPHEN, A. C., I929. Local extinction of a recently abundant lamellibranch. Nature, Lond., Vol. I23, p. 606.

Fauvel, P., I927. Polychètes sédentaires. Faune Fr., T. I6, 494 pp.

FISHER, N., I93I. Local extinction of a recently abundant mollusk. F. Conch., Vol. I9, pp. $152-3$.

Forbes, E. \& Hanley, S., 1853. A History of British Mollusca, and their Shells. Vols. I-4. London: Van Voorst.

FoRD, E., I923. Animal communities of the level sea-bottom in the waters adjacent to Plymouth. F. mar. biol. Ass. U.K., Vol. 13, pp. 164-224.

- 1925. On the growth of some lamellibranchs in relation to the food supply of fishes. F. mar. biol. Ass. U.K., Vol. I3, pp. 531-59.

ForsteR, G. R., I953. A new dredge for collecting burrowing animals. F. mar. biol. Ass. U.K., Vol. 32, pp. 193-8.

Gustafson, G., 1934. On the Thalassinidea of the Swedish west coast. Ark. Zool., Bd. 28, pp. I-19.

HAGMEIER, A., I925. Vorläufiger Bericht über die vorbereitenden Untersuchungen der Bodenfauna der Deutschen Bucht mit dem Petersen-Bodengreifer. Ber. dtsch. Komm. Meeresforsch., N.F., Bd. I, pp. 247-72.

Hepper, B. T., I957. Notes on Mytilus galloprovincialis Lamarck in Great Britain. F. mar. biol. Ass. U.K., Vol. 36, pp. 33-40. 
Holme, N. A., I950. The bottom-fauna of Great West Bay. F. mar. biol. Ass. U.K., Vol. 29, pp. 163-83.

- 1953. The biomass of the bottom fauna in the English Channel off Plymouth. F. mar. biol. Ass. U.K., Vol. 32, pp. I-49.

- 1954. The ecology of British species of Ensis. F. mar. biol. Ass. U.K., Vol. 33, pp. $145-72$.

- 1959. The British species of Lutraria (Lamellibranchia), with a description of L. angustior Philippi. F. mar. biol. Ass. U.K., Vol. 38, pp. 557-68.

Hunt, A. R., I884. On the influence of wave-currents on the fauna inhabiting shallow seas. F. Linn. Soc. Zool.), Vol. r8, pp. 262-74.

HunT, O. D., 1925. The food of the bottom fauna of the Plymouth fishing grounds. F. mar. biol. Ass. U.K., Vol. 13, pp. 560-99.

JefFreys, J. G., I862-9. British Conchology, or an Account of the Mollusca which now Inhabit the British Isles and the surrounding seas. 5 vols. London: Van Voorst.

JoNES, N. S., I956. The fauna and biomass of a muddy sand deposit off Port Erin, Isle of Man. F. Anim. Ecol., Vol. 25, pp. 217-52.

Kevan, D. K., 1934. Spisula (Mactra) subtruncata (da Costa) in the Firth of Forth. Scot. Nat., No. 205, p. 27.

KING, W. B. R., I954. The geological history of the English Channel. Quart. F. geol. Soc. Lond., Vol. I10, pp. 77-Ior.

KnIGHT, G. A. F., I90I. Marine Mollusca and Brachiopoda. Fauna, Flora and Geology of the Clyde Area, pp. 189-208. Glasgow: British Association.

KNUDSEN, J., I949. Scaphopoda. Zool. Iceland, Vol. 4, part 62, 7 pp.

KRISTENSEN, I., I959. The coastal waters of the Netherlands as an environment of molluscan life. Basteria, Vol. 23, Suppl., pp. 18-46.

KYLE, H. M., I903. Notes on the physical conditions existing within the line from Start Point to Portland. F. mar. biol. Ass. U.K., Vol. 6, pp. 528-40.

LoosanofF, V. L. \& Tommers, F. D., 1948. Effect of suspended silt and other substances on rate of feeding of oysters. Science, Vol. 107, pp. 69-70.

LumBY, J. R., 1935. Salinity and temperature of the English Channel. Atlas of charts. Fish. Invest., Lond., Ser. 2, Vol. I4, No. 3.

MacGinitie, G. H., I949. Natural History of Marine Animals. 473 pp. New York: McGraw-Hill.

MCINTYRE, A. D., 1958. The ecology of Scottish inshore fishing grounds. I. The bottom fauna of east coast grounds. Mar. Res. Scot., I958, No. I, 24 pp.

Madsen, F. J., I949. Marine Bivalvia. Zool. Iceland, Vol. 4, part 63, II6 pp.

Marine Biological Association, 1957. Plymouth Marine Fauna, 3rd ed. Plymouth.

Matthews, D. J., I9II. Report on the physical conditions in the English Channel and adjacent waters, 1906, with a note on the mean conditions for 1903-1909. Rep. N. Sea. Fish. Invest. Comm., No. 3, pp. 269-82.

Moore, H. B., 1937. Marine fauna of the Isle of Man. Proc. Lpool biol. Soc., Vol. 50, pp. I-293.

MoRTENSEN, T., 1927. Handbook of the Echinoderms of the British Isles. 47I pp. Oxford University Press.

Morton, J. E., 1959. The habits and feeding organs of Dentalium entalis. F. mar. biol. Ass. U.K., Vol. 38, pp. 225-38.

Nichols, A. R., I900. A list of the marine Mollusca of Ireland. Proc. R. Irish Acad., Vol. 5, pp. 477-662.

ORTON, J. H., 1920. Sea temperature, breeding and distribution in marine animals. F. mar. biol. Ass. U.K., Vol. I2, pp. 339-66.

- 1937. Some interrelations between bivalve spatfalls, hydrography and fisheries. Nature, Lond., Vol. I40, pp. 505-6. 
Orton, J. H., I950. The recent extension in the distribution of the American slipper limpet, Crepidula fornicata, into Lyme Bay in the English Channel. Proc. malac. Soc., Vol. 28, pp. I68-84.

PIKE, R. B., 1953. The bopyrid parasites of the Anomura from British and Irish waters. F. Linn. Soc. (Zool.), Vol. 42, pp. 219-38.

Pratje, O., I950. Die Bodenbedeckung des Englischen Kanals und die maximalen Gezeitenstromgeschwindigkeiten. Dtsch. hydrogr. Z., Bd. 3, pp. $20 \mathrm{I}-5$.

Pratt, D. M., I953. Abundance and growth of Venus mercenaria and Callocardia morrhuana in relation to the character of bottom sediments. F. mar. Res., Vol. I2, pp. 60-74.

Prenant, M., I932. Études de bionomie intercotidale. La Baie et la Pointe de Quiberon. Trav. Sta. biol. Roscoff, T. I0, pp. 37-103.

_ 1939. Études de bionomie intercotídale. La Baie de Douarnenez et ses abords. Bull. biol., T. 73, pp. 45I-76.

REES, C. B., I95I. Continuous plankton records: first report on the distribution of lamellibranch larvae in the North Sea. Hull Bull. mar. Ecol., Vol. 3, pp. 105-34.

- 1954. Continuous plankton records: the distribution of lamellibranch larvae in the North Sea, 1950-51. Hull Bull. mar. Ecol., Vol. 4, pp. 21-46.

REEs, W. J., 1950. The distribution of Octopus vulgaris in British waters. F. mar. biol. Ass. U.K., Vol. 29, pp. 36I-78.

ReEs, W. J. \& Lumby, J. R., I954. The abundance of Octopus in the English Channel. f. mar. biol. Ass. U.K., Vol. 33, pp. 515-36.

Rendall, R., 1956. Mollusca Orcadensia. Proc. roy. Soc. Edinb., B, Vol. 66, pp. I3I201.

Rice, T. R. \& SMith, R. J., I958. Filtering rates of the hard clam (Venus mercenaria) determined with radioactive phytoplankton, U.S. Fish and Wildlife Service, Fishery Bull., Vol. 58, No. 129, pp. 71-82.

Roushdy, H. M. \& HANSEN, V. K., I960. Ophiuroids feeding on phytoplankton. Nature, Lond., Vol. 188, pp. 517-18.

RuSSELL, F. S., I935. On the value of certain plankton animals as indicators of water movements in the English Channel and North Sea. F. mar. biol. Ass. U.K., Vol. 20, pp. 309-32.

Scottish Marine Biological Association, 196r. The Fauna of the Clyde Sea Area: Mollusca (in the Press).

Southward, A. J., I960. On changes of sea temperature in the English Channel. F. mar. biol. Ass. U.K., Vol. 39, pp. 449-58.

- 196I. The distribution of some plankton animals in the English Channel and Western Approaches. I. Samples taken with stramin nets in 1955 and 1957. F. mar. biol. Ass. U.K., Vol. 4r, pp. 17-35.

Spooner, G. M. \& Holme, N. A., I96r. Bottom fauna off the Dorset coast. Proc. Dorset nat. Hist. Fld Cl., Vol. 82 (in the Press).

Station Biologique de Roscoff, I95i. Inventaire de la faune marine de Roscoff. Mollusques. Trav. Sta. biol. Roscoff, Suppl. 5, 80 pp.

STEPHEN, A. C., I933. Studies on the Scottish marine fauna: the natural faunistic divisions of the North Sea as shown by the quantitative distribution of the molluscs. Trans. roy. Soc. Edinb., Vol. 57, pp. 60I-I6.

- 1934. Studies on the Scottish marine fauna; quantitative distribution of the echinoderms and the natural faunistic divisions of the North Sea. Trans. roy. Soc. Edinb., Vol. 57, pp. 777-87.

— 1960. British echiurids (Echiuroidea), sipunculids (Sipunculoidea) and priapulids (Priapuloidea). With keys and notes for the identification of the species. Linn. Soc., Synopses of the British Fauna, No. 12, 27 pp. 
Thorson, G., I94I. Marine Gastropoda Prosobranchiata. Zool. Iceland, Vol. 4, Part 60, $150 \mathrm{pp}$.

Thorson, G., 1946. Reproduction and larval development of Danish marine bottom invertebrates, with special reference to the planktonic larvae in the Sound (Øresund). Medd. Komm. Havundersøg., Kbh., Ser. Plankton, Bd. 4, No. I, 523 pp.

TodD, G. B., I9or. Echinodermata. Fauna, Flora and Geology of the Clyde Area, pp. 364-6. Glasgow: British Association.

TodD, R. A., 1903. Notes on the invertebrate fauna and fish-food of the bays between the Start and Exmouth. F. mar. biol. Ass. U.K., Vol. 6, pp. 54I-6I. I906-7. Marine Zoology. Victoria Co. Hist.: Devonshire, pp. 13I-58.

URK, R. M. VAN, 1957. Een strandschelp van onze kust herontdekt: Spisula elliptica (Brown). Basteria, Vol. 21, pp. 31-7.

URSIN, E., I952. Change in the composition of the bottom fauna of the Dogger Bank area. Nature, Lond., Vol. I70, p. 324.

- 1960. A quantitative investigation of the echinoderm fauna of the central North Sea. Medd. Komm. Havundersøg., Kbh., N.S., Bd. 2, Nr. 24, 204 pp.

VeVERS, H. G., 1952. A photographic survey of certain areas of sea floor near Plymouth. F. mar. biol. Ass. U.K., Vol. 31, pp. 215-21.

WILson, D. P., I958. Some problems in larval ecology related to the localized distribution of bottom animals. Perspectives in Marine Biology. Ed. A. A. BuzzatiTraverso, pp. 87-103. University of California Press.

— \& ARMSTRONG, F. A. J., 1958. Biological differences between sea waters: experiments in 1954 and 1955 . F. mar. biol. Ass. U.K., Vol. 37, pp. 33I-48.

WINCKWORTH, R., 1932. The British marine Mollusca. F. Conch., Vol. I9, pp. 2 I I-52.

YoNGE, C. M., I946. On the habits of Turritella communis Risso. F. mar. biol. Ass. U.K., Vol. 26, pp. 377-80.

1959. On the structure, biology and systematic position of Pharus legumen (L.). F. mar. biol. Ass. U.K., Vol. 38, pp. 277-90.

\section{APPENDIX}

STANDARDIZATION OF TERMS USED IN THIS PAPER

The Plymouth area stretches along the coast from Looe to Bolt Tail, at the eastward end of Bigbury Bay, and extends seawards within a radius of about 20 miles from Plymouth. Records from Salcombe are here included in the Plymouth area, except in Table 8.

Western and eastern halves of the Channel lie on either side of St Alban's Head. The term central Channel is loosely applied to the middle parts of the length of the Channel. MidChannel refers to the central east-west axis of the Channel (i.e. to 'mid-stream').

FAUNA LIST

Although I am indebted to a number of authorities for checking or identifying certain species, the list is in the main confined to those with which I am personally familiar. This was particularly important for the molluscs where it was necessary to sort through large quantities of sievings to check dead shell records.

The coverage of different groups is as follows:

Lamellibranchs, scaphopods and echinoderms-as complete as possible.

Gastropods-fairly complete, so far as living specimens go, but records of species taken only as dead shells are generally omitted.

Crustaceans-mainly burrowing species only. The sieve mesh was too large to take many amphipods, and these have not been included.

Other groups-confined to a few larger or more conspicuous species.

Specimens identified to genus only are not to be considered as species additional to those of the same genus in which specific identity is given. Thus records of Natica sp. are probably all either $N$. catena or $N$. alderi. 
In the list of living specimens, station number is followed by numbers of individuals, in parentheses.

Dead shells are usually recorded as the number of stations at which each species was recorded in each of the fourteen areas. For example, 2-8 means records at 8 stations in area 2. The few stations not included in these areas are also included in the list. For certain more critical species numbers of dead shells at each station are recorded. These are rather approximate, but are based on the following frequency code:

\begin{tabular}{lc} 
& Lamellibranchs (nos. of valves) \\
A (abundant) & Several hundred \\
C (common) & $>32$ \\
F (frequent) & $17-32$ \\
O (occasional) & $9-16$ \\
R (rare) & $\mathrm{I}-8$ \\
\multicolumn{1}{c}{ +, present; ?, identity queried. }
\end{tabular}

When living specimens were taken, dead shells are not recorded from the same station.

Nomenclature follows the Plymouth Marine Fauna (Marine Biological Association, 1957). Other species are listed by Winckworth (1932) and Stephen (1960).

\section{PHYLUM MOLLUSCA}

\section{Class LAMELLIBRANCHIA}

Nucula nucleus (L.)

Living: 2 (2), 3 (4), 7 (I2), II (I4), I4 (I), 17 (85), I8 (I), 20 (2), 22 (8), 35 (2 ?), 36 (40), 39 (I), 48 (2), 54 (88), 64 (II), 79 (I), 98 (I). Dead shells not recorded.

$N$. hanleyi Winckworth

Living: 7 (I), 48 (I), 58 (I), 6I (9), 74-I (22), 74-2 (2), 8I (2), 82 (II), 83 (2), 85 (I), 9I (I ?), 104 (3), I20 (13), I23 (7), I33 (I), I34 (I), I35 (3), I37 (9), I63 (I). Dead shells not recorded.

N. turgida Leckenby \& Marshall

Living: I (5), 4 (39), I2 (2), I8 (2), I9 (5I), 20 (5), 32 (8), 42 (5), 44 (3), 50 (I), 5I (6), 52 (I4), 53 (I20), 66 (I8), 67 (I7), 68 (13), 69 (3), 70 (I), 71 (36), 73 (2), 77 (I), 79 (53), I05 (I4), I Iо (I), I24 (I), I27 (6), I36 (2), I40 (I4), I4I (9), I59 (II), I63 (I), I66 (2), I69 (I2), I70 (I). Dead shells not recorded.

Glycymeris glycymeris (L.)

Living: 7 (2), 74-I (4), I35 (2), I38 (9). Dead: $1-6,2-8,3-I, 4-6,5-3,7-1,8-3$, 9-3, IO-I, I4-2. Stn. I2O.

Pinna fragilis Pennant

Dead: 104 (I).

Chlamys tigerina (Müller)

Dead: $1-3,2-8,3-5,4-6,5-2,7-1$. Stn. 120.

C. opercularis (L.)

Living: 4 (I), 4I (I), 57 (6), 82 (I), 85 (2), 86 (2), 98 (2), IOI (2), IO2 (2), I54 (I), I56 (I). Dead shells were recorded at nearly every station.
C. varia (L.)

Living: 26 (I), 55 (2), 64 (I), 85 (2), 9I (I), 95 (8), 96 (I), 97 (2), 98 (4), I00 (2), IOI (4, I ?), I67 (3). Dead: 2-I, 3-I, $4-4,5-5,7-2,8-3,9-7$, 10-6, $11-8$, I2-9, I3-9, I4-9. Stns. 65-2, 74-2.

C. distorta (da Costa)

Living: 86 (I), 98 (I), I67 (I). Dead: I-2, $2-7,3-4,4-3,5-6,6-2,7-2,9-1,12-3$, I3-7, 14-3.

Pecten maximus (L.)

Living: 56 (I), I58 (I), I63 (2). Dead: I-4, 2-6, 3-4, 4-4, 5-I, 6-I, 8-2, I I-3, I2-2, I3-3, I4-2. Stn. I2O.

Astarte sulcata (da Costa)

Dead: I33 (2), I39 (2).

Cyprina islandica (L.)

Living: 42 (I), 46 (I). Dead: I-I, 2-I, $3-2,7-3,8-2$, IO-I. Stn. I2O.

Diplodonta rotundata (Montagu)

Living: 48 (2), 56 (I), 62 (I), 78 (2), 8I (I), IO3 (I), IO4 (2), II2 (I2), I2O (4), I 29 (5), I33 (I), I48 (I), I53 (I). Dead: $I-4,2-4,3-3,4-4,5-3,6-I, 7-3,8-4$, II $-2,12-5, I_{3}-4, I_{4}-5$. Stns. 74-2, I2O.

Thyasira flexuosa (Montagu)

Living: 4 (I), I2 (4), I8 (2), I9 (I), 32 (6), 44 (I), 49 (6), 50 (2), 5 I (3), 52 (I), 53 (4), 77 (I), 79 (I), I24 (3), I40 (4), I69 (I), I 70 (3). Dead: I-4, 2-4, 3-2, 4-3, 5-4, $6-5,7-3,8-4,14-1$. Stns. 79, 120. 
Lucinoma borealis (L.)

Living: I (I), I20 (I), I 27 (2), I36 (I), I40 (2), I60 (I). Dead: 4 (I), 82 (I), II 7 (3), I I9(I), I 20 (O), I2I (I ?), I23 (I), I 27 (8), I29 (I), I36 (3), I 40 (I), I4I (5), I 5 I (4), I66 (I).

Myrtea spinifera (Montagu)

Living: I I9 (I), I26 (2). Dead: Iro (13), II3 (2), II7 (I7), I20 (I), I35 (4), I 54 (2), I7I (I), I72 (II).

Lepton squamosum (Montagu)

Living: I8 (I), II7 (2). Dead: 2-2, 3-4, $4-3,5-1,6-3,7-4,8-4,11-I, 12-2$, I3-I, I4-I. Stn. I2O.

Mysella bidentata (Montagu)

Living: 12 (I), I8 (I), 32 (I), 50 (2), 5I (I), 52 (2), 53 (7), 7I (I), 79 (3), I 24 (5), I4I (2). Dead: I-2, 2-2, 3-2, 6-4. Stn. 79 .

Montacuta substriata (Montagu)

Commensal with Spatangus purpureus. Living: 88 (2).

M. ferruginosa (Montagu)

Living: 49 (I), 5 I (I), 53 (I), 60 (5), 67 (2), I05 (I), II9 (I), I26 (I), I69 (3). Dead: I-2, 2-4, 3-I, 4-I, 5-4, 6-6, 7-5, 8-I, I2-I, I3-2, I4-2. Stn. 79.

Laevicardium crassum (Gmelin)

Living: 48 (I), 83 (2), IO2 (I), I23 (I), I 35 (2), I 37 (2), I38 (I), I48 (2), I 54 (3), I56 (I), I57 (3). Dead: I-4, 2-9, 3-4, $4-5,5-2,6-1,7-2,8-4,9-2$, I I-4, I2-6, I3-9, I4-6. Stns. 37, 65-2, 74-2, I20.

Cardium echinatum $\mathrm{L}$.

Living: 4 (2), 5 (I), I8 (I), 32 (2), 66 (I ?), 67 (I ?), 7I (I), 75 (I), 76 (I), 79 (I), I03 (I), I04 (I), I05 (I), 107 (I), I I6 (I), I 8 (I), I 24 (I, I ?), I36 (I, 2 ?), I4I (I), I50 (2), I5I (I), I60 (2). Dead: I-4, $2-3,3-6,4-3,5-5,6-6,7-6,8-4$, 10-3, I2-4, I3-3, I4-7. Stns. 32, 79, 120 .

Gouldia minima (Montagu)

Living: I34 (I), I37 (I), I38 (I). Dead: II2 (2), II3 (II), II6 (2), I20 (9), I23 (I2), I27 (5), I29 (I), I30 (I), I33 (8), I34 (I8), I35 (I3), I36 (I), I37 (10), I38 (5), I39 (I2), I54 (9), I55 (3), I57 (13).

Callista chione (L.)

Dead: II7 (I), I20 (C), I22 (I), I26 (I), I36 (O), I38 (I), I4I (I).

Dosinia exoleta (L.)

Living: 8I (I), I2I (I), I30 (I), I37 (3), I38 (I5). Dead: $I-I, 2-8,3-3,4-2,5-1$, 7-I, 8-3, 9-I.
D. lupinus (L.)

Living: 45 (I), I04 (2), I05 (2), II6 (2), I I 7 (I), I I9 (6), I 20 (74), I 23 (2), I24(I), I 27 (I3), I 29 (4 ?), I36 (I), I40 (4), I4I (9), I50 (I), I52 (3), I53 (II), I59 (I). Dead: $1-7,2-6,3-6,4-3,5-5,6-3,7-2$, 8-I. Stn. I20.

Dosinia sp.

Living: I40 (I). Dead: I-I, 2-I, 3-I, 4-I, 7-2, 8-2.

Venus verrucosa $\mathrm{L}$.

Living: 2 (5), 3 (5), ro (1), 25 (6), 26 (3), 27 (II), 28 (2), 29 (3), 30 (2), 37 (2), 39 (2), 40 (I0), 54 (I), 55 (I), 97 (I8), 98 (2), IO0 (3), IOI (I). Dead: $2-3,4-1$, 8-I, 9-5, IO-3, II-2, I2-I. Stns. 22, 28, 29, 36, 40.

V. casina $\mathrm{L}$.

Living: 9 (2), Io (2), I37 (I). Dead: I-3, 2-4, 3-2, 8-1, 9-3.

V. ovata Pennant

Living: 5 (I), 7 (7), II (I), 35 (3), 36 (I), 37 (2), 39 (I), 48 (I48), 49 (I7), 55 (I), 56 (2), 9I (7), 92 (I), IOI (I), IO2 (7), I59 (I), I63 (2). Dead shells occurred in all areas.

V. fasciata (da Costa)

Living: IO2 (I), II3 (I), I28 (2), I34 (I), I37 (4), I38 (9), I63 (I). Dead: I-6, 2-8, 3-7, 4-6, 5-I, 7-I, 8-I, 9-2, I3-I (I valve only). Stn. I20.

V. striatula (da Costa)

Living: I (3), 4 (I I), 5 (I), 4I (3), 42 (2), 44 (2), 45 (14), 46 (3), 49 (8), 50 (I), 5 I (4), 52 (2), 53 (8), IO5 (7), I IO (4), I 20 (I), I36 (32), I40 (2), I4I (24), I52 (I), I63 (2), I66 (I), I70 (I), I7 I (I), I73 (I). Dead: I-7, 2-4, 3-8, 4-6, 5-8, 6-10, 7-8, 8-5. Stn. 120.

Venerupis rhomboides (Pennant)

Living: 2 (2), 3 (2), 4 (I), 5 (4), 7 (3), 9 (3), IO (2), I6 (I), I7 (IO), 20 (I), 22 (5), 25 (35), 26 (23), 27 (39), 28 (30), 29 (15), 30 (II), 35 (3), 36 (25), 37 (9), 39 (6), 40 (44), 47 (3), 48 (3), 55 (5), 56 (9), 57 (13), 58 (22), 59 (I), 64 (I), 83 (I), 85 (5), 90 (4), 91 (3), 92 (3), 97 (3), 98 (7), IO0 (I), IOI (I), IO2 (4), I03 (2), I04 (2), I2I (I), I 22 (2), I 34 (I), I 37 (6), I38 (I8), I 54 (I), I 55 (I), I63 (I). Dead shells occurred in all areas.

$V$. pullastra (Montagu)

Living: I7 (I), 3I (3), 36 (I). Dead: 17 (2), 35 (2), 64 (3). 
Venerupis aurea (Gmelin)

Living: 2 (I9), 3 (I4). Dead: I (6).

Mysia undata (Pennant)

Living: I (3), 4 (I), I8 (I), 4I (3), 42 (I ?), 43 (I), 44 (2), 5 I (I), 82 (I), 83 (I), 9I (I), I05 (I), I06 (I), I09 (I), I IO (2), I I9 (I), I40 (I), I60 (I). Dead: I-3, 2-5, 3-3, $4-4,5-2,6-4,7-6,8-5,9-1,10-1,12-6$, 13-3, 14-2. Stns. 74-2, I20.

Spisula subtruncata (da Costa)

Living: I (25), 4 (I30), 5 (I), I8 (9), 20 (22), 2I (I), 32 (2), 35 (I), 4I (I), 42 (25), 43 (27), 44 (9), 48 (3), 49 (2), 52 (16), 53 (I5), I05 (5), I36 (2), I66 (5), I69 (6). Dead: $\mathrm{I}-5,2-3,3-3,4-\mathrm{I}, 5-8,6-8,7-8$, $8-5$, I0-4, I2-3, I3-I, I4-7. Stns. 32, 79, 120.

S. solida (L.)

Living: I65 (2), I68 (I2). Dead: 2-2, IO-I ?. Stn. 28 .

S. elliptica (Brown)

See Van Urk (1957). Living: 8 (1), 9 (2), I0 (2), I5 (I), 24 (2), 34 (I), 36 (I), 38 (I), 56 (2), 58 (I), 60 (I), 6r (2), 62 (I), 63 (I), 65-2 (I), 67 (I), 72 (2), 74-I (2), 82 (2), 83 (I), 9I (4), 98 (3), 99 (I), I02 (I), I65 (I). Dead: I-2, 2-2, $3-2,4-3,5-5,6-1,7-3,8-2,9-4$, ro-3, I I-7, I2-9, I3-I0, I4-Io. Stns. 24, 37, $38,39,65-2,74-2,79,120$.

Spisula sp.

Dead: 62 (I), 67 (I)

Mactra corallina (L.)

Living: 4 (I), 42 (I ?), 43 (8), 44 (I), 66 (3), 67 (I), 68 (2), I 50 (2), I 59 (I), I69 (I). Dead: $2-2,3-2,4-I, 5-4,6-I, 7-I, 8-4$, IO-3, I2-2, I3-I, I4-8.

Lutraria lutraria (L.)

Living: I8 (I), 45 (2), 50 (3), 5 I (3), 52 (2), 53 (3), 76 (I), I07 (I), I40 (2), I5I (4). Dead: $2-3,3-3,4-I, 5-3,6-4,7-3$, IO-I. Stn. 120.

L. angustior Philippi

See Holme (I959). Living: I22 (I), I 37 (2), I38 (I), I39 (I), I 57 (I). Dead: $\mathrm{I}-2,2-7,3-4,4-4,5-2,7-\mathrm{I}, 8-5,9-4$, II-I, I3-3, I4-2. Stns. 26, 40, I20.

L. magna (da Costa)

Dead: 7 (2); 26 (ca. 6), 27 (I2), 38 (I), 40 (I), 6I (I).

Lutraria sp.

Living: I4I (4). Dead: I57 (I).

Gari depressa (Pennant)

Dead: $136(\mathrm{I})$.
G. costulata (Turton)

Living: I37 (I); I57 (I). Dead: I23 (I), I 33 (I), I34 (I), I 35 (7), I38 (I), I 57 (I).

G. fervensis (Gmelin)

Living: 4I (4), 42 (3), 44 (3), 6I (I), 7I (I), 72 (I), 82 (I), I04 (2), I05 (4), I20 (3), I27 (I), I36 (I), I4I (I), I50 (2), I66 (I). Dead: I-6, 2-5, 3-4, 4-2, 5-4, 6-3, 7-6, $8-4,9-I$, IO-I, I2-3, I3-I. Stn. I2O.

G. tellinella (Lamarck)

Living: I2O (2), I23 (3), I 57 (I). Dead: 55 (2), 62 (I ?), 92 (I), IO2 (I), I03 (I), II3 (F), I2O (O), I23 (F), I 27 (2), I 28 (I), I 33 (2), I 34 (7), I 35 (C), I36(O), I37 (5), I39 (6), I48 (I), I5I (I), I54 (F), I57 (F), I59 (I), I63 (I), I65 (I).

Solecurtus chamasolen (da Costa)

Living: I08 (2), I09 (3), I I0 (I), I I6 (I), I I7 (I), I I9 (2), I 24 (4), I 26 (4), I 52 (I), I53 (I), I73 (5). Dead: I-3, 2-I, 3-5, $4-2,6-3,7-2,8-1$. Stn. I20.

S. scopula (Turton)

Dead: I-I, 2-4, 3-I, 4-3, I4-I (I valve only).

Abra prismatica (Montagu)

Living: 60 (ca. 36), 6 I (ca. I I ), 65-I (4, I ?), 68 (I), 70 (I), 73 (5), 74-I (I), 88 (3), 9I (I), I20 (4), I4I (2), I64 (I). Dead: 60 (C), 6 I (O), 62 (I), 63 (R), 65-I (O), 65-2 (2), 67 (3), 68 (5), 69 (2), 70 (I), $7 \mathrm{I}(\mathrm{O}), 72$ (R), 73 (5), 78 (3), 8I (I), 82 (I2), 83 (5), 87 (I), 88 (F), 89 (I), 90 (I), 9I (I), I03 (I), I04 (2), I05 (I), I 20 (9), I 24 (I), I 26 (8), I 27 (3), I 29 (I), I36 (4), I4I (3).

A. alba (W. Wood)

May include a few $A$. nitida (Müller), which were not distinguished with certainty. Living: I (I6), 4 (I77), 20 (2), 22 (24), 4I (2), 48 (5), 5I (4), 52 (2), 53 (4), 60 (ca. 3I), 64 (I 5), 66 (ca. 55), 67 (56), 68 (7), 69 (3), 70 (I), 71 (15), 72 (I), 73 (26), 74-I (I), 76 (I), 77 (ca. 57), 79 (57), 83 (I ?), 9I (3), IO4 (3), IO5 (34), II (2), I2O (2), I40 (3), I 59 (4), I63 (I), I66 (2), I69 (I), I70 (I). Dead shells in all areas except 9.

Arcopagia crassa (Pennant)

Living: I23 (I), I35 (3), I38 (I), I55 (2), I57 (I), I6I (I). Dead: I-4, 2-8, 3-3, 4-5, 7-I, 9-I. Stn. I2O. 
Tellina donacina $\mathrm{L}$.

Living: 48 (I), 56 (I), 75 (I), 8I (I), 83 (I), 85 (2), 9I (3), IO2 (3), II2 (3), II6 (I), I 20 (20), I28 (I), I34 (I), I35 (2), I6I (I). Dead: $\mathrm{I}-3,2-4,3-3,4-5,5-3,6-1,7-2$, $8-3,9-2$, II $-3,12-7,1_{3}-8,14-6$. Stns. 74-2, 120.

T. pygmaea Lovén

Living: II3 (I), I20 (2). Dead: 82 (I), 83 (I), I20 (8), I23 (8), I35 (I), I36 (I), I57 (2).

T. fabula Gmelin

Living: I2 (I6), I9 (3), 50 (6), 52 (I), 53 (4), 60 (70), 66 (I), 67 (I6), 68 (I0), 69 (7), 70 (I), 7I (2I), 73 (I9), I36 (97), I40 (I), I4I (I06), I69 (2). Dead: I-I, $2-3,3-2,4-2,5-1,6-5,7-5,8-2,10-4$, I2-4, I3-3, I4-7. Stns. 79, I2O.

T. tenuis da Costa

Living: 33 (I), 72 (I). Dead: 13-2, I4-3.

T. squalida Montagu

Living: I36 (2), I4I (4). Dead: I (2), 4 (R), 50 (3), I I 7 (4), I20 (I), I36 (I0), I40 (I), I4I (8).

Donax vittatus (da Costa)

Dead: 5-I, 7-I, I2-I, I4-5.

Phaxas pellucidus (Pennant)

Living: I (I), 4 (20), 4I (5), 42 (I2), 43 (I9), 44 (45), 45 (3), 48 (8), 49 (I), 52 (2), 53 (9), 60 (I), 63 (I), 67 (2), 70 (I), 7 I (I0), 73 (2), 77 (4), IO4 (I4), I05 (I3), I I I (I), II2 (I), II3 (I), I 20 (2), I 24 (I), I26 (I), I27 (I3), I36 (8), I40 (ca. I4), I4I (IO), I5I (I), I53 (3), I59 (ca. 34), I66 (I), I73 (I). Dead: I-3, 2-2, 3-2, $4-I, 5-3,6-8,7-7,8-5$, IO-I, I2-I, I3-2, I4-I. Stns. 79, I20.

Solen marginatus Pulteney

Living: I9 (I ?), 34 (I), 35 (I). Dead: 8-I, IO-4, I2-2, I4-I.

Ensis ensis (L.)

Living: I (I ?), 4 (I), I9 (2), 42 (7), 43 (3), 44 (13), 50 (I0), 60 (8), 61 (I), 67 (8), 68 (ca. 10), 69 (9), 70 (ca. 26), 71 (42), 72 (8), 73 (3), 74-I (I ?), IO5 (I5), I40 (2 ?), I50 (I), I60 (I), I66 (I), I72 (I). Dead: $2-I, 3-2,5-2,7-4,8-3$, IO-3, I2-3, 13-4, I4-7. Stns. 32, I20.

E. arcuatus (Jeffreys)

Living: 9 (I), 28 (4), 29 (I), 83 (2), IO2 (I, I ?), II3 (I), I35 (3), I 37 (3), I65 (2). Dead: I-I, 2-2, 4-I, 5-3, 8-2, II-I, I2-I ?, I3-5, I4-3. Stn. I2O.
E. siliqua (L.)

Living: 50 (I ?), I5I (I), I64 (ca. 3), I66 (3, 5 ?). Dead: 3-2, 5-2, 6-2.

Ensis sp.

Living: I36 (I), I66 (I). Dead: I-I, 2-4, 3-I, 4-I, 5-3, 7-2, 9-I, IO-I, I3-I.

Saxicavella jeffreysi Winckworth

Living: I8 (24), 20 (3), 77 (69), 79 (I). Dead: 2-I, IO-2, I2-I, I4-2. Stns. 32, 79.

Corbula gibba (Olivi)

Living: I (I), 4 (IO), I8 (I), 20 (I), 32 (I), 42 (2), 44 (2), 45 (I), 48 (2), 49 (I), 50 (I), 6I (2), 7 I (9), 73 (2), 76 (I), I04 (I), I08 (I), I I9 (I), I 27 (I), I 36 (I), I4I (2), I63 (2). Dead shells in all areas except 9 and $I I$.

Mya truncata L.

$\star$ Siphons only. Living: $20\left(4\right.$ ? $\left.^{\star}\right), 64$ (I), 77 (I ? *). Dead: 3-I, 4-I, 7-2, 9-2, IO-2, II $-5,12-4, I_{3}-3,14-3$. Stns. 22, 26, 27 (36 (?), 39, 40.

Lyonsia norvegica Macgillivray

Living: 9I (I), II6 (I). Dead: 9I (I), I63 (I).

Pandora albida (Röding)

Living: 4 (I), I9 (I), 6I (I), 66 (I). Dead: 8-I, IO-3, I4-I. Stn. 32.

$P$. pinna (Montagu)

Living: 42 (2 ?), I40 (I), I59 (I), I63 (2). Dead: 2-I, 4-I, 7-I, I2-I.

Pandora sp.

Dead: 4-I, 6-I, 7-I, I2-I, I3-I, I4-I. Stns. 79, 120.

Thracia phaseolina (Lamarck)

Living: 44 (6), 45 (I), 53 (3), I I9 (I), I36 (I, 2 ?), I4I (4), I66 (I). Dead: I-3, $2-3,3-2,6-2,8-I$ ?. Stn. 120.

T. convexa (W. Wood)

Living: 44 (I), I08 (I), II6 (I), I52 (2). Dead: 4-I, 6-2, 7-I.

$T$. villosiuscula (Macgillivray)

Living: I 20 (I), I23 (I), I33 (I), I38 (I). Dead: II3 (6), I20 (I2), I23 (5), I34 (6), I35 (I4), I36 (7), I37 (6), I38 (I), I39 (I), I4I (I), I 57 (3), I59 (I).

Cochlodesma praetenue (Montagu)

Living: II2 (I), I 20 (I), I27 (I), I29 (I2). Dead: I20 (I8), I23 (I), I27 (I), I29 (F). 


\section{Class Gastropoda}

Calliostoma zizyphinum (L.)

Living: 25 (I), 54 (I), 57 (I), 64 (I), 98 (2), IOO (3), IOI (7), I67 (7). Dead: 4-I, 5-I, 6-I, 7-2, 9-3, IO-2, I I-6, I2-4, 13-3, 14-3. Stns. 40, 65-2, 74-2.

Gibbula magus (L.)

Living: 2 (2), 3 (I), I7 (I). Dead: I-I, 2-4, 3-2, 5-I, 8-I, 9-I, I3-2. Stns. 30, I2O.

Turritella communis Risso

Living: I (2), 4 (IOI), 5 (20), 46 (ca. 530), 47 (ca. 48), 48 (3), 49 (ca. 220), 50 (2), 5 I (I), 52 (III), 53 (ca. 370), II9 (II4), I 20 (4), I70 (I), I73 (33). Dead: I-4, $2-3,3-4,4-3,5-6,6-8,7-8,8-4$, IO-I. Stn. I20.

Aporrhais pes-pelecani (L.)

Living: 5 (2), I66 (3). Dead: 2-2, 3-I, 5-2, 7-I. Stn. 120.

Natica catena (da Costa)

Living: I9 (I ?). Dead: 8I (I), I20 (2), I55 (I).

$N$. alderi (Forbes)

Living: 4 (I), 9 (I), I9 (I), 20 (2), 42 (2), 50 (3), 54 (I), 60 (9), 64 (I), 66 (9), 67 (2), 68 (I), 69 (I2), 70 (4), 7I (37), 72 (2), 73 (10), 74-I (2), 78 (I), 79 (I), 82 (2), IO2 (I), I05 (7), I I9 (I), I 23 (I), I 27 (I), I36 (2), I40 (3), I 5 I (2), I 59 (4), I66 (4), I69 (I). Dead: I-2, 2-7, 3-I, $4-3,5-3,6-2,7-3,8-1,11-1,12-6$, I3-3, I4-9. Stns. 79, I20.

Natica sp.

Living: 105 (I). Dead shells in many areas.

Calyptraea chinensis (L.)

Living: 3 (I), 4 (I), 37 (I), 48 (2), I38 (I), I63 (2). Dead: $2-2,5-2,6-I, 7-I, 8-I$, IO-I, I I-I.

Crepidula fornicata (L.)

Living: $2(60+), 3$ (I00), 4 (I), 7 (2), II (ca. I300), I2 (3), I6 (C), I7 (36+), I9 (8), 20 (8), 22 (ca. 45), 24 (I), 30 (I), 37 (2), 53 (I), 57 (2), 60 (I), 64 (I06), 9I (5), 93 (3), 95 (I), 97 (2), 98 (I), I63 (6), I64 (I), I67 (2). Dead: 5-2, 7-I, 8-I, 9-2, IO-7, II-7, I2-I, I3-2. Stns. 22, 24, 27, 40 .
Buccinum undatum $\mathrm{L}$.

Living: 4 (I), II (I), I6 (I), I8 (2), I9 (6), 36 (I), 49 (I), 53 (I), 57 (I), 58 (I), 7 I (3), 76 (I), 83 (I), 85 (I), 87 (I), 95 (I), 98 (I), IOI (I), IO2 (I), I68 (5). Dead: 3-I, 5-2, 6-I, 7-I, 8-4, IO-2, II-3, I2-4, I3-2, I4-I. Stn. I2O.

Nassarius reticulatus (L.)

Living: 2 (6), 3 (4), 4 (3), II (4), I2 (I), I8(I), I9(I2), 20 (2), 24(3), 52 (2), 53(2), 60 (7), 64 (I), 66 (9), 67 (10), 68 (10), 69 (7), 70 (7), 71 (23), 72 (I), 73 (3), 74-I (3), 88 (I), I36 (I), I 50 (2), I 5 I (I2), I 59 (I), I60 (3), I63 (6), I66 (2), I67 (3), I68 (I), I7I (I), I72 (I). Dead: 2-2, 3-2, 4-2, 5-4, 7-3, 8-1, 9-1, 10-2, II-I, I2-5, I3-3, I4-5. Stns. 30, 35, 40, 79 .

N. incrassatus (Ström)

Living: 2 (I), 57 (I), 85 (I ?), 9I (I), IOI (4), I34 (I). Dead: $2-4,3-4,4-2,5-2$, 6-2, 7-I, 8-I, 9-I, IO-2, II-2, I2-5, I3-6, I4-3.

N. pygmaeus (Lamarck)

* May include some dead shells. Living: I $\left(8^{\star}\right), 4$ (56*), I8 (I), I9 (I), 20 (I ?), 44 (I), 46 (6), 48 (I), 49 (5), 50 (7), 52 (2), 53 (2), I69 (3). Dead: $3^{-2}, 4^{-I}$, $5-2,6-3,7-4,8-2$, IO-2, I2-I, I3-I, I4-5. Stn. 79 .

Nassarius sp.

Dead: 89 (I).

Cylichna cylindracea (Pennant)

Living: 52 (I). Dead: $I-3,2-2,3-I, 5-I$, $6-4,7-4,8-2$. Stn. 120.

Scaphander lignarius (L.)

Living: I05 (I), II3 (I), I27 (I), I50 (I), I52 (I), I59 (I). Dead: I-2, 3-I. Stn. I2O.

Philine quadripartita Ascanius

Living: I (I), 4 (I3), I2 (2), 32 (I ?), 44 (I ?), 49 (I ?), 5I (3 ?), 52 (4 ?), 53 (2), 7 I (I), II9 (6 ?), I4I (II). Dead: I-I ?, 2-I ?, I4-I. Stn. 79.

$P$. catena (Montagu)

Dead: II3 (I). 


\section{Class Scaphopoda}

Dentalium entalis $\mathrm{L}$.

Living: I27 (I). Dead: II6 (3), II7 (5), I 20 (9), I 24 (I), I25 (2), I26 (I), 127 (6).

Dentalium vulgare da Costa

Living: 7 (I), 8 (I), 4I (4), 6r (2), 62 (I), I04 (I), I63 (I). Dead: 5-2, 7-3, 8-5,
9-2, I0-5, I2-5, 13-4, I4-7. Stns. 22, $24,32,74-2$. A proportion of the dead shells were worn and could not be identified with certainty. However, the records indicate no overlap of $D$. vulgare and $D$. entalis, so that the above records are probably all of $D$. vulgare.

\section{Class Cephalopoda}

Sepiola atlantica d'Orbigny 54 (I); 60 (I).

\section{PHYLUM COELENTERATA}

\section{Ceriathus lloydi Gosse}

45 (ca. 50), 46 (2), 47 (2), 48 (13), 90 (3), 9I (I), 103 (2), I04 (3), 107 (I), I 12 (7),

\section{PHYLUM ANNELIDA}

Aphrodite aculeata L.

I (I), 4 (7), II (I), I2 (I), 20 (2), 48 (I), 52 (I), 57 (I), 67 (2), 69 (I), 7 I (6), 72 (I), 73 (4), 74-I (I), 76 (I), 77 (I), 83 (I), 84 (I), IO4 (I).

Chaetopterus variopedatus (Renier)

II6 (3), I20 (I), I53 (II), I63 (4), I65 (I).

\section{Arenicola marina (L.)} 66 (2 ?), 73 (2).

Pallasia murata Allen

5 (I), IO2 (I), II6 (I). Empty tubes: II7 (I).

Living: I34 (C). Empty tubes: I-4, 2-3, 3-2, 4-2, 5-I, I3-I. Stn. I2O.

\section{PHYLUM ECHIUROIDEA}

Maxmulleria (=Thalassema) lankesteri (Herdman) I8 (ca. 6), 77 (ca. 6), 79 (I), 80 (ca. 20).

\section{PHYLUM SIPUNCULOIDEA}

Golfingia ( = Phascolosoma) elongata

(Keferstein)

II (8), 22 (ca. I5).

G. (= Phascolosoma) vulgaris (Blainville)

5 (2), II (I), 28 (I), 29 (I), 47 (3), 48 (I),

77 (I ?), 97 (I ?), I03 (2), 108 (2), 109

(2 ?), II7 (I), I39 (I).

Golfingia (= Phascolosoma) sp. I24 (I), I63 (I).
Phascolion strombi (Montagu)

I (3), 4 (96), I2 (3), I9 (29), 20 (I), 42 (3), 45 (I), 50 (2), 52 (20), 53 (2), 6I (I), I27 (I), I 53 (I), I 57 (I), I63 (6).

Phascolosoma (= Physcosoma) granulatum (F. S. Leuckart)

93 (I ?), 95 (I ?).

Sipunculus nudus L. 127 (I).

\section{SUB-PHYLUM CRUSTACEA}

Squilla desmaresti Risso 22 (I), 57 (I), IO2 (I).

Pseudione callianassae Kossmann

Gill-parasite of Callianassa, see Pike (1953). Female with attached male, forming I pair. 43 (I pr), I07 (I pr), I09 (2 pr), I52 (I pr).
Ione thoracica (Montagu)

Gill-parasite of Callianassa. See Pike (1953). 44 (I pr), I08 (P), I09 (I pr), I73 (昂).

Gyge branchialis Cornalia \& Panceri

Gill-parasite of Upogebia. 5 ( $1 \mathrm{pr}$, on U. stellata), 108 ( $\mathrm{pr}$, on U. deltaura). 
Alpheus glaber (Olivi) IOI (I), I52 (2 ?).

faxea nocturna (Chiereghin) 47 (I), I52 (2).

Callianassa subterranea (Montagu)

42 (4), 43 (I), 44 (ca. I3), 45 (ca. 4), 48 (I ?), I03 (I), I04 (I), I05 (I), I06 (I), I07 (I7), I08 (I9), I09 (26), I IO (ca. 20), II 2 (2), I I 7 (I), I 24 (I), I 27 (I), I 52 (I2), I7I (3), I72 (II), I73 (II).

Upogebia deltaura (Leach)

I (I ?), 5 (I), II (I), I7 (I), I8 (4), 25 (I), 40 (3), 47 (2), 8I (I), 90 (I ?), 99 (2), IO2 (7), IO3 (3), IO4 (I), IO8 (3), I I 2 (5),
II3 (I), II6(I5), II7(7), II9 (2), I39 (I), 153 (I).

U. stellata (Montagu)

5 (I), 7 (I), IO4 (I), II6 (I), I39 (5), I48 (I).

Corystes cassivelaunus (Pennant)

50 (I), 5I (I), 66 (I), 69 (I), 7I (I), 75 (I), I4I (2), I59 (I), I72 (I).

Atelecyclus septemdentatus (Montagu)

IOI (I), III (I), I I6 (I), I26 (I).

Thia polita Leach I05 (I).

Goneplax angulata (Pennant)

5 (2), 49 (I), 5I (I), 52 (I), I08 (I).

\section{PHYLUM ECHINODERMATA}

Astropecten irregularis (Pennant)

43 (3), 44 (I), 45 (2), 49(I), I05 (I), 106 (2), I 27 (I), I36 (I), I40 (I), I4I (6), I 50 (I), I5I (I), I53 (I), I59 (I).

Asterina gibbosa (Pennant) I2I (I).

Henricia sanguinolenta (O. F. Müller) IOO (3), IOI (4), I 28 (I).

Asterias rubens $\mathrm{L}$.

I6 (I), 76 (I), II5 (6), II6 (I), II8 (I), I 20 (I), I27 (I), I30 (I), I33 (4), I38 (I), I40 (I), I4I (5), I63 (2), I67 (5), I69 (I), I7I (3).

Marthasterias glacialis (L).

I 28 (2), I30 (3), I38 (I), I 55 (2), I 56 (I).

Ophiothrix fragilis (Abildgaard)

25 (I), 82 (5), 84 (5), 86 (40), 87 (2), 98 (2), II5 (2), I I6 (I), I20 (I), I 23 (I24), I24 (7), I 25 (I), I 26 (I), I 28 (3), I30 (I), I 33 (7), I34 (2), I37 (I), I40 (I), I4I (2), I 42 (740), I 49 (I), I 52 (I), I 58 (2).

Ophiocomina nigra (Abildgaard)

II5 (7), II6 (6), II7 (I), I 23 (5), I25 (I), I27 (5), I37 (I), I4O (II), I42 (4I), I48 (4), I49 (2).

Amphiura chiajei Forbes

I34 (3), I55 (I).

A. securigera (Düben \& Koren) I55 (I), I59 (I).

A. filiformis (O. F. Müller)

I (6), 4 (I), I9 (3), 20 (2), 32 (6I), 4I (I6), 42 (I5), 43 (8), 44 (4), 45 (II), 48 (I), 49 (I5), 50 (3), 5I (I8), 52 (I4), 53 (20), I05 (2), I06 (5), 107 (4), I08 (3), I09 (I), I IO (9), I I I (I0), I I2 (I), I I6(9), I I 7 (I), II9 (I20), I24 (6), I26 (I9), I27 (5),
I 48 (2), I 53 (3), I 54 (I), I60 (7), I63 (I), I 66 (I), I69 (5), I 70 (9), I 7 I (9), I 72 (38), 173 (I).

Acrocnida brachiata (Montagu)

4 (I ?), I2 (36), I3 (I), I4 (2), I9 (8), 20 (2), 32 (I), 4I (I), 42 (I), 50 (22), 5 I (I), 60 (I), 63 (I0), 66 (3), 67 (5), 7 I (I), 72 (I), 73 (I), 74-I (2), 76 (I), 77 (2), 79 (9), 83 (I), I05 (I), I I6 (I ?), I I9 (I), I 24 (273), I 25 (I), I 26 (2I), I 27 (24), I4I (2), I69 (I).

Ophiura texturata Lamarck

4 (I), I9 (I), 4I (I), 52 (I), 66 (I), 67 (I0), 68 (25), 69 (19), 70 (12), 71 (17), 72 (22), 73 (I), 79 (4), 81 (2), 82 (I), 83 (I), IIO (2), I II (2), II 2 (2), II3 (I), II6 (I), I 34 (I), I40 (I), I4I (I), I 52 (I), I 59 (9), I60 (9), I63 (2), I66 (2).

O. albida Forbes

5 (I), I9 (I), 45 (I), 52 (9 ?), 56 (I), 60 (2), 71 (2), 72 (6), 73 (I), 74-2 (I), 75 (2), 76 (1), 79 (7), 81 (2), 82 (5), 83 (27), 84 (I), 87 (27), 88 (3), 90 (I), 9I (7), I I2 (3), I I8 (3), I 22 (2), I 23 (3), I 27 (2), I 34 (I), I48 (I), I55 (I), I63 (4).

O. affinis Lütken

I05 (I), I4I (I), I57 (I), I65 (I), I7I (2).

Ophiura sp.

53 (3).

Echimus sp.

Mainly small specimens, of either E. esculentus L. or Psammechinus miliaris (Gmelin). 39 (I), 48 (I), 55 (I), 56 (2), 57 (I), 85 (4), 86 (I), 93 (I), 97 (I), IOO (I), IOI (I), IO2 (I), I28 (I*), I 54 (I). ( ${ }^{\star}$. esculentus.) 
Echinocyamus pusillus (O. F. Müller) 48 (I), 49 (I), 82 (2), 83 (3), 9I (2), I04 (7), I 20 (I), I 34 (I), I 37 (I), I 39 (I), I 42 (I), I 54 (I), I 55 (I), I7I (I).

Spatangus purpureus O. F. Müller 87 (2), 88 (8), I35 (2), I57 (I).

Echinocardium cordatum (Pennant) 42 (4), 43 (20), 44 (ca. I9), 45 (9), 46 (2), 49 (2), 50 (10), 5 I (5), 52 (I ?), 53 (4), 60 (ca. I5), 63 (I ?), 65-I (ca. I6), 65-2 (10), 66 (3), 67 (15), 68 (ca. 34), 69 (3), 70 (I), 7I (ca. 36), 72 (3), 73 (10), 74-I (2), 76 (5), 82 (9), 88 (I), I05 (ca. 8), I06 (20), 107 (I), I08 (I), I I0 (5), I I I (I), I I9 (5), I 24 (5), I 26 (3), I 27 (5), I36 (2), I4I (2), I5O (2), I5I (ca. 6), I 59 (I), I60 (Io), I69 (ca. II), I70 (6), I 7 I (2), I72 (2), I73 (5).

E. flavescens (O. F. Müller) I29 (3).

E. pennatifidum Norman II3 (I).

Echinocardium sp. I23 (I), I39 (I), I40 (I), I64 (I).

Holothuria forskali Delle Chiaje I 22 (I ?), I30 (I), I52 (I).

\section{PHYLUM CHORDATA}

Amphioxus lanceolatus (Pallas) I35 (I), I37 (6).
Cucumaria elongata Düben \& Koren I07 (I), I 52 (2), I 53 (I), I 73 (I).

C. normani Pace I42 (I), I67 (2).

Thyone sp.

8I (I ?), II7 (4), I34 (2 ?), I37 (I ?), I39 (I ?), I48 (2 ?), I5O (I).

Pseudocucumis mixta Östergren I 49 (I), I 54 (I), I 55 (I).

Holothuroidea. Genus not determined. II2 (I), II3 (I), II5 (I), I I6 (8), I34 (2), I35 (2).

Leptosynapta inhaerens (O. F. Müller) 4 (I), 43 (I), 45 (2), 47 (I), I07 (I), I08 (I), IO9 (I), I IO (ca. 5), I24 (3), I27 (I), I52 (2), I60 (I), I7I (I), I72 (2), 173 (3).

Labidoplax digitata (Montagu) 50 (ca. 3), 52 (I), 53 (3), IO4 (I), I I7 (I), I I9 (2), I 20 (2), I 24 (I), I 26 (I), I 27 (4), I29 (I), I36 (2), I40 (3), I4I (I4), I 59 (I), I60 (I).

Synaptidae (Leptosynapta or Labidoplax) 42 (I), 5 I (I).

LIST OF LAMELLIBRANCHS TAKEN LIVING, BUT NOT INCLUDED IN THE ABOVE FAUNA LIST

Most occurred at only $\mathrm{I}$ or 2 stations

Arca lactea L., Modiolus barbatus (L.), Modiolus sp., Musculus marmoratus (Forbes), Musculus sp., Anomiidae spp., Lima loscombi Sowerby, Cardium ovale Sowerby, C. scabrum Philippi, C. exiguum Gmelin, C. (Parvicardium) sp., Hiatella spp., Thracia distorta (Montagu).

RECORDS OF WESTERN SPECIES OTHER THAN IN DREDGE SURVEY

(See Fig. 6)

GREAT WeSt BAY. Sixty stations worked by Mr E. Ford in November 1923, using a $\frac{1}{10} \mathrm{~m}^{2}$ Petersen grab. One haul at most stations. Much the same area was covered in a survey in I948 (Holme, I950).

Plymouth AREA. Ford's (1923) survey. Also twenty stations worked in 1950 (Holme, 1953), and a few other grab stations, all outside Plymouth breakwater.

SOUTH CORNISH COAST. Nine stations in St Austell Bay, November 1950, and thirty-eight stations in June and November 1954, from St Austell Bay to the Lizard. One or two grab hauls at most stations. Also shore-collecting records at St Antony-in-Roseland, Helford and Manaccan in the Falmouth area, 1949-60.

Records, apart from those published as above:

Chlamys tigerina. Nil.

Myrtea spinifera

Station M I $\quad 50^{\circ} \mathrm{I} 6 \cdot \mathrm{I}^{\prime} \mathrm{N} ., 4^{\circ} 46 \cdot 0^{\prime} \mathrm{W}$. I8 m I6.xi.50 One Station $\mathrm{M}_{2} \quad 50^{\circ} \mathrm{I} 6.35^{\prime} \mathrm{N} ., 4^{\circ} 46 \cdot 2^{\prime} \mathrm{W}$. $18 \mathrm{~m}$ I6.xi.50 One 
Gouldia minima

Station $\mathrm{S}_{29} \quad 5^{\circ} 00^{\circ} 9^{\prime} \mathrm{N}$., $5^{\circ} 03^{\circ} 8^{\prime} \mathrm{W} . \quad 20 \mathrm{~m}$ 5.xi.54 Two

(Still taken in small numbers, living, in the Eddystone shell-gravel).

\section{Gari tellinella}

Station M $7 \quad 50^{\circ} 19^{\prime} 9^{\prime} \mathrm{N} ., 4^{\circ} 43^{\prime} 8^{\prime} \mathrm{W}$. Io m $16 . x \mathrm{i} .50$ One

Station S II $50^{\circ} 10^{\circ} 65^{\prime}$ N., $4^{\circ} 57^{\circ} \mathrm{I}^{\prime} \mathrm{W} . \quad 27 \mathrm{~m} \quad 3 \cdot x i .54$ One

Station S $24 \quad 49^{\circ} 59^{\circ} 09^{\prime}$ N., $5^{\circ} 09^{\prime} 5^{\prime}$ W. $18 \mathrm{~m}$ 4.xi.54 One

Station S $25 \quad 49^{\circ} 58^{\prime} 6^{\prime} \mathrm{N}$., $5^{\circ}$ o9.6 $6^{\prime}$ W. $35 \mathrm{~m} \quad$ 4.xi.54 One

Station S $27 \quad 50^{\circ} \mathrm{Or} \cdot 5^{\prime} \mathrm{N}$., $5^{\circ}$ 05.3' W. I3 m 4.xi.54 One

Tellina pygmaea

Station S 17 Helford River. $\quad 9 \mathrm{~m} \quad$ 4.xi.54 Seven

Also record from Plymouth Sound (Marine Biological Association, 1957).

Thracia villosiuscula

Station S I9 Helford River. $15 \mathrm{~m} \quad$ 4.xi.54 Five

Station S $23 \quad 49^{\circ} 59^{\circ} 95^{\prime}$ N., $5^{\circ} 08 \cdot 75^{\prime}$ W. $27 \mathrm{~m}$ 4.xi.54 One

Station S $26 \quad 49^{\circ} 58 \cdot 85^{\prime}$ N., $5^{\circ} 07 \cdot 2^{\prime}$ W. $51 \mathrm{rm} \quad 4 . x i .54$ One

Cochlodesma praetenue. See Holme (1953) for several Plymouth records

Station S $9 \quad 50^{\circ} 11^{\prime} 35^{\prime} \mathrm{N} ., 4^{\circ} 57^{\prime} 15^{\prime} \mathrm{W} .22 \mathrm{~m} \quad 3 \cdot x i .54$ Fourteen

Station S II $50^{\circ} 10^{\circ} 65^{\prime} \mathrm{N} ., 4^{\circ} 57^{\circ} \mathrm{I}^{\prime} \mathrm{W} . \quad 27 \mathrm{~m} \quad 3 . x i .54$ Thirteen

Station $\mathrm{S}_{17}$ Helford River. $99 \mathrm{~m} \quad 4 . x i .54$ One

St Antony-in-Roseland (shore)-2 specimens, I955

Dentalium entalis. Not taken at any of the stations detailed above.

The only additional record, at the mouth of the Channel, is:

Station $24 \quad 49^{\circ} \circ 5^{\prime}$ N., $\quad 6^{\circ} 35^{\prime}$ W. ca. $120 \mathrm{~m}$. 6.vi.51 Three in $0.45 \mathrm{~m}^{2}$

(also taken subsequently in this area from R.R.S. Discovery II). The record of Dentalium sp. at Station $3 \mathrm{I}$ in Great West Bay (Holme, I950) is of $D$. vulgare.

Dates of sampling as follows:

\section{STATION LIST}

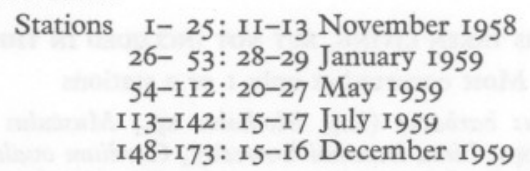

Stations are listed in order from west to east, the samples making up each of the fourteen areas (Fig. 4) being shown unbracketed.

\section{Deposits}

Abbreviations

m., mud; s., sand; gr., gravel; st., stones; r., rock; sh., shell; Lith., Lithothamnion gravel; c., coarse; f., fine; m., medium; cln., clean. -, no soil sample. +, interpret as 'with some'.

\section{SIZE OF SAMPLE}

$\frac{1}{4}, \frac{1}{2}, \frac{3}{4}, \mathrm{I}, 2$, etc., numbers of baths-full (I bath $=$ roughly 201 .).

$\frac{1}{2} \mathrm{~F}, \mathrm{~F}$, dredge net half-full, full.

$\mathrm{T}$, sample contained a number of stones, no finer soil.

W, soil sample small or nil, due to washing out.

II, two dredge-hauls.

\section{TREATMENT}

$\mathrm{H}$, hosed down or otherwise roughly sorted on deck.

$2 \cdot 2$, all sample passed through $2 \cdot 2 \mathrm{~mm}$ sieve.

$2 \cdot 2(\mathrm{I}) / \mathrm{H}$, one bath-full passed through $2 \cdot 2 \mathrm{~mm}$ sieve, the rest sorted on deck. 
$2 \cdot 2 / 5 / \mathrm{H}$, a small (unmeasured) portion passed through $2 \cdot 2 \mathrm{~mm}$ sieve, another portion through $5 \mathrm{~mm}$ sieve, the rest sorted on deck.

-, no sample.

All, whole sample kept (unsieved).

Sieve meshes (square holes): $2 \cdot 2,2 \cdot 5,5$ and II.5 mm.

\begin{tabular}{|c|c|c|c|c|c|c|}
\hline Station & Posit & & $\begin{array}{c}\text { Depth } \\
\text { (m) }\end{array}$ & Deposit & $\begin{array}{l}\text { Size of } \\
\text { sample }\end{array}$ & Treatment \\
\hline Area I & & & & & & \\
\hline I2I & $50^{\circ} 06 \cdot 2^{\prime} \mathrm{N}$ & $5^{\circ} 31 \cdot 55^{\prime} \mathrm{W}$. & 18 & st. & $\mathrm{T}$ & $\mathrm{H}$ \\
\hline 124 & $50^{\circ} 05^{\prime} 3^{\prime} \mathrm{N}$ & $5^{\circ} 30.65^{\prime} \mathrm{W}$. & 29 & f.m.s. & I & $2 \cdot 2$ \\
\hline 126 & $50^{\circ} \mathrm{o} 4^{\prime} 8^{\prime} \mathrm{N}$ & $5^{\circ} 30.5^{\prime} \mathrm{W}$ & 37 & m.s. & $1 / 3$ & $2 \cdot 2$ \\
\hline 122 & $50^{\circ} 06 \cdot 3^{\prime} \mathrm{N}$. & $5^{\circ} 30.3^{\prime} \mathrm{W}$ & 20 & gr. + st. & $\frac{1}{2} \mathrm{~T}$ & $\mathrm{H}$ \\
\hline 127 & $50^{\circ} 03 \cdot \mathrm{I}^{\prime} \mathrm{N}$ & $5^{\circ} 29.85^{\prime} \mathrm{W}$. & 48 & m.s. & II. W; W & $2 \cdot 2$ \\
\hline 125 & $50^{\circ} 05^{\circ} 0^{\prime} \mathrm{N}$. & $5^{\circ} 29.35^{\prime} \mathrm{W}$. & 33 & gr. + st. & $\mathrm{T}$ & $\mathrm{H}$ \\
\hline 123 & $50^{\circ} 06 \cdot 0^{\prime} \mathrm{N}$ & $5^{\circ} 29^{\circ} 0^{\prime} \mathrm{W}$. & 26 & f.sh.gr. + st. & $1 \frac{1}{2}$ & $2 \cdot 2(\mathrm{I}) / \mathrm{H}$ \\
\hline 129 & $49^{\circ} 59^{\circ} 85^{\prime} \mathrm{N}$. & $5^{\circ} 28.05^{\prime} \mathrm{W}$. & 54 & - & W & All \\
\hline 128 & $50^{\circ} 02.9^{\prime} \mathrm{N}$. & $5^{\circ} 25 \cdot 4^{\prime} \mathrm{W}$ & 32 & st. + gr. & $\mathrm{T}$ & $\mathrm{H}$ \\
\hline I30 & $50^{\circ}$ or ${ }^{\prime} 2^{\prime} \mathrm{N}$ & $5^{\circ} 22 \cdot 2^{\prime} \mathrm{W}$ & $4 \mathrm{I}$ & ? r. & - & $\mathrm{H}$ \\
\hline (I3I & $50^{\circ} 00 \cdot 4^{\prime} \mathrm{N}$ & $5^{\circ} \mathrm{r} 8.0^{\prime} \mathrm{W}$ & 26.5 & ? r. & - & $\mathrm{H})$ \\
\hline (132 & $49^{\circ} 59^{\prime} 3^{\prime} \mathrm{N}$ & $5^{\circ} 08 \cdot 8^{\prime} \mathrm{W}$ & 26.5 & ? r. & - & - \\
\hline Area 2 & & & & & & \\
\hline I33 & $49^{\circ} 59^{\circ} 45^{\prime} \mathrm{N}$. & $5^{\circ} 07 \cdot 4^{\prime} \mathrm{W}$. & 39 & gr. & $\frac{1}{2}$ & $\mathrm{H}$ \\
\hline 134 & $50^{\circ} \mathrm{OI} \cdot 55^{\prime} \mathrm{N}$. & $5^{\circ} 04^{\prime} 55^{\prime} \mathrm{W}$. & 27 & m. + Lith. & $\mathrm{I}_{2}^{\frac{1}{2}}$ & $2 \cdot 2(\mathrm{I} / \mathrm{IO}) / \mathrm{II} \cdot 5$ \\
\hline I35 & $50^{\circ}$ or $\cdot 45^{\prime} \mathrm{N}$. & $5^{\circ} 04^{\circ} 05^{\prime} \mathrm{W}$. & 35 & f.sh.gr. & 2 & $2 \cdot 2(\mathrm{I} / \mathrm{IO}) / 5 / \mathrm{H}$ \\
\hline 136 & $50^{\circ} 05^{\prime} 75^{\prime} \mathrm{N}$. & $5^{\circ} 05^{\prime} \mathrm{W}$ & 8 & cln.s. & 2 & $2 \cdot 2$ \\
\hline 138 & $50^{\circ} 07 \cdot 2^{\prime} \mathrm{N}$ & $5^{\circ} 04^{\prime} 3^{\prime} \mathrm{W}$ & ? 17 & Lith. & $\mathrm{F}$ & $2 \cdot 2 / \mathrm{II}^{\prime} 5 / \mathrm{H}$ \\
\hline I37 & $50^{\circ} 06.65^{\prime} \mathrm{N}$. & $5^{\circ} 03^{\prime} 4^{\prime} \mathrm{W}$ & I7 & Lith. & F. & $2 \cdot 2 / 5 / \mathrm{II} \cdot 5 / \mathrm{H}$ \\
\hline I39 & $50^{\circ} 08 \cdot 35^{\prime} \mathrm{N}$. & $4^{\circ} 57.5^{\prime} \mathrm{W}$ & 32 & m. +f.gr. & $\mathrm{F}$ & $2 \cdot 2 / 5 / \mathrm{H}$ \\
\hline I40 & $50^{\circ}$ II $\cdot 6^{\prime} \mathrm{N}$ & $4^{\circ} 56 \cdot 25^{\prime} \mathrm{W}$. & 25 & cln.s. & $\frac{3}{4}$ & $2 \cdot 2$ \\
\hline I4I & $50^{\circ} \mathrm{I} 2 \cdot 0^{\prime} \mathrm{N}$ & $4^{\circ} 56.3^{\prime} W$ & 17 & cln.s. & $2 \frac{1}{2}$ & $2 \cdot 2$ \\
\hline 142 & $50^{\circ} \mathrm{12} .55^{\prime} \mathrm{N}$. & $4^{\circ} 50 \cdot 2^{\prime} \mathrm{W}$ & 27 & st. & $\mathrm{T}$ & $\mathrm{H}$ \\
\hline (I20 & $50^{\circ} 13.4^{\prime} \mathrm{N}$ & $4^{\circ} 50.15^{\prime} \mathrm{W}$. & 26 & c.s. & 2 & $2 \cdot 2)$ \\
\hline Area 3 & & & & & & \\
\hline II 7 & $50^{\circ} 17 \cdot 25^{\prime} \mathrm{N}$. & $4^{\circ} 43.55^{\prime} \mathrm{W}$. & 29 & gr.s. + m. & $\mathrm{F}$ & $2 \cdot 2 / 5 / \mathrm{II} \cdot 5 / \mathrm{H}$ \\
\hline I I 8 & $50^{\circ} \mathrm{I} 6.45^{\prime} \mathrm{N}$. & $4^{\circ} 46^{\circ} 0^{\prime} \mathrm{W}$ & 19 & st. & $\mathrm{T}$ & $\mathrm{H}$ \\
\hline II9 & $50^{\circ} 17.5^{\prime} \mathrm{N}$ & $4^{\circ} 45^{\circ} 35^{\prime} \mathrm{W}$. & 17 & f.m.s. & 3 & $2 \cdot 2$ \\
\hline II6 & $50^{\circ}$ I $8 \cdot 45^{\prime} \mathrm{N}$. & $4^{\circ} 36.6^{\prime} \mathrm{W}$. & 35 & m.s. + shale & $\mathrm{F}$ & $2 \cdot 2(\mathrm{I}) / \mathrm{H}$ \\
\hline II5 & $50^{\circ} \mathrm{I} 8 \cdot 6^{\prime} \mathrm{N}$ & $4^{\circ} 30.85^{\prime} \mathrm{W}$. & 46 & - & $\mathrm{W}$ & All \\
\hline (II4 & $50^{\circ}$ I9. I' N. & $4^{\circ} 27 \cdot 2^{\prime} \mathrm{W}$ & $37 / 35$ & st. & T II & $-)$ \\
\hline II3 & $50^{\circ} \mathrm{I} 9 \cdot \mathrm{I}^{\prime} \mathrm{N}$ & $4^{\circ} 22 \cdot 25^{\prime} \mathrm{W}$. & 16 & f.sh.gr. & $I_{\frac{1}{2}}$ & $2 \cdot 2(\mathrm{I}) / \mathrm{H}$ \\
\hline 148 & $50^{\circ} \mathrm{I} 9 \cdot \mathrm{I}^{\prime} \mathrm{N}$ & $4^{\circ} \mathrm{I} 9.3^{\prime} \mathrm{W}$ & 32 & st. + m.gr. & $I_{\frac{1}{2}}$ & $\mathrm{H}$ \\
\hline 149 & $50^{\circ} 19 \cdot 7^{\prime} \mathrm{N}$ & $4^{\circ} \mathrm{I} 5.8^{\prime} \mathrm{W}$ & 24 & st. & $\frac{1}{2}$ & $\mathrm{H}$ \\
\hline I50 & $50^{\circ} \mathrm{I} 9.75^{\prime} \mathrm{N}$. & $4^{\circ}$ I $5.25^{\prime} \mathrm{W}$. & 23 & - & W & All \\
\hline I5I & $50^{\circ} 19.75^{\prime} \mathrm{N}$. & $4^{\circ} 14.9^{\prime} \mathrm{W}$ & I4 & cln.f.s. & $\frac{1}{2}$ & $2 \cdot 2$ \\
\hline Area 4 & & & & & & \\
\hline I52 & $50^{\circ} \mathrm{I7} \cdot 8^{\prime} \mathrm{N}$. & $4^{\circ} 16.9^{\prime} \mathrm{W}$. & 42 & $\mathrm{~m}$ & $\mathrm{~F}$ & $2 \cdot 2\left(\mathrm{I} \frac{1}{2}\right) / \mathrm{H}$ \\
\hline I53 & $50^{\circ} 17 \cdot 2^{\prime} \mathrm{N}$ & $4^{\circ} 07^{\prime} \mathrm{W}$ & 43 & m.s. + gr. & $I_{\frac{1}{2}}$ & $2 \cdot 2\left(\frac{3}{4}\right) / \mathrm{H}$ \\
\hline I54 & $50^{\circ} 17.0^{\prime} \mathrm{N}$. & $4^{\circ} 03.9^{\prime} \mathrm{W}$. & 37.5 & sh.gr. & I & $2 \cdot 2\left(\frac{1}{4}\right) / \mathrm{H}$ \\
\hline I 55 & $50^{\circ}$ 16.9' N. & $4^{\circ} \mathrm{OI} \cdot 4^{\prime} \mathrm{W}$ & $37 \cdot 5$ & sh.gr. & $\mathrm{I}_{\frac{1}{2}}$ & $2 \cdot 2\left(\frac{1}{4}\right) / \mathrm{H}$ \\
\hline 156 & $50^{\circ} \mathrm{I} 6.3^{\prime} \mathrm{N}$ & $3^{\circ} 59^{\circ} 8^{\prime} \mathrm{W}$ & 39.5 & - & $\mathrm{T}$ & All \\
\hline I57 & $50^{\circ} 15^{\circ} 05^{\prime} \mathrm{N}$. & $3^{\circ} 58.85^{\prime} \mathrm{W}$. & 39.5 & cln.sh.gr. & $3-4$ & $2 \cdot 2\left(\frac{1}{4}\right) / 5(\mathrm{I}) / \mathrm{H}$ \\
\hline I58 & $50^{\circ} \mathrm{1} 6.5^{\prime} \mathrm{N}$ & $3^{\circ} 56.5^{\prime} \mathrm{W}$ & 28.5 & m.sh.gr. & $3-4$ & \\
\hline$(\mathrm{I} 62$ & $50^{\circ} 14^{\prime} 4^{\prime} \mathrm{N}$ & $3^{\circ} 56 \cdot 4^{\prime} \mathrm{W}$ & 31 & - & W & $\rightarrow$ \\
\hline I59 & $50^{\circ} 15^{\circ} 25^{\prime} \mathrm{N}$. & $3^{\circ} 55^{\circ} 55^{\prime} \mathrm{W}$ & $3 I$ & f.s. & $\frac{1}{2}$ & $2 \cdot 2$ \\
\hline 160 & $50^{\circ}$ I $5.8^{\prime} \mathrm{N}$ & $3^{\circ} 53^{\circ} 95^{\prime} \mathrm{W}$. & 22 & f.s. & $\frac{1}{4}$ & $2 \cdot 2$ \\
\hline I6I & $50^{\circ} 15^{\circ} 0^{\prime} \mathrm{N}$. & $3^{\circ} 53.5^{\prime} \mathrm{W}$ & $25 \cdot 5$ & st. + sh.gr. & F & $2 \cdot 2\left(\frac{1}{4}\right) / 5\left(\frac{1}{4}\right) / \mathrm{H}$ \\
\hline
\end{tabular}




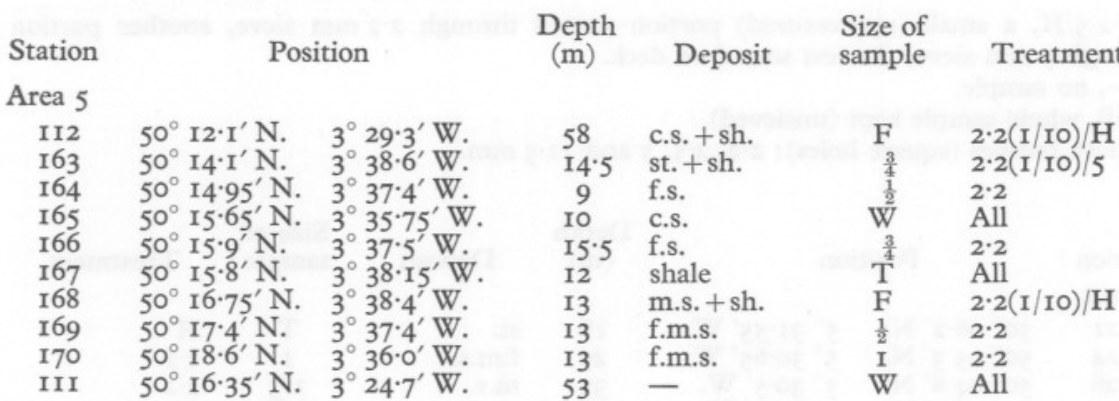

Area 6

I7I

I72

173

5 I

52

53

49

I IO

I09

108 $50^{\circ} 19 \cdot 5^{\prime} \mathrm{N} . \quad 3^{\circ} 31 \cdot 15^{\prime} \mathrm{W}$. $50^{\circ} 2 r^{\prime} 7^{\prime} \mathrm{N} . \quad 3^{\circ} 29^{\prime} 35^{\prime} \mathrm{W}$ $50^{\circ} 20 \cdot 2^{\prime} \mathrm{N} . \quad 3^{\circ} 23 \cdot 4^{\prime} \mathrm{W}$. $50^{\circ} 25^{\circ} 0^{\prime} \mathrm{N}$. $\quad 3^{\circ} 29 \cdot 75^{\prime} \mathrm{W}$ $50^{\circ} 25^{\prime} 8^{\prime} \mathrm{N}$. $\quad 3^{\circ} 29 \cdot 7^{\prime} \mathrm{W}$. $50^{\circ} 26 \cdot 4^{\prime}$ N. $\quad 3^{\circ} 29^{\prime} 7^{\prime} \mathrm{W}$. $50^{\circ} 30 \cdot 5^{\prime} \mathrm{N} . \quad 3^{\circ} 28 \cdot 6^{\prime} \mathrm{W}$ $50^{\circ} 20^{\circ} 0^{\prime} \mathrm{N} . \quad 3^{\circ} 20.5^{\prime} \mathrm{W}$. $50^{\circ} 23^{\circ} 85^{\prime}$ N. $3^{\circ} 19^{\circ} 4^{\prime} \mathrm{W}$ $50^{\circ} 26.65^{\prime} \mathrm{N} . \quad 3^{\circ} 14.7^{\prime} \mathrm{W}$.
Area 7 50
48
47
107
46
106
45
105
44
104

$50^{\circ} 3 I^{\prime} 85^{\prime} \mathrm{N} . \quad 3^{\circ} 28 \cdot 6^{\prime} \mathrm{W}$. $50^{\circ} 31^{\prime} \cdot 55^{\prime} \mathrm{N} . \quad 3^{\circ} 18.25^{\prime} \mathrm{W}$ $50^{\circ} 33^{\circ} 7^{\prime} \mathrm{N} . \quad 3^{\circ} 13.65^{\prime} \mathrm{W}$ $50^{\circ} 28 \cdot 6^{\prime} \mathrm{N} . \quad 3^{\circ} 09 \cdot 7^{\prime} \mathrm{W}$ $50^{\circ} 35 \cdot 1^{\prime} \mathrm{N} . \quad 3^{\circ} 08 \cdot 25^{\prime} \mathrm{W}$ $50^{\circ} 29 \cdot 85^{\prime} \mathrm{N} .3^{\circ} 03 \cdot 2^{\prime} \mathrm{W}$ $50^{\circ} 36.05^{\prime} \mathrm{N} . \quad 3^{\circ} 02 \cdot 4^{\prime} \mathrm{W}$. $50^{\circ} 30 \cdot 4^{\prime} \mathrm{N} . \quad 2^{\circ} 57 \cdot 2^{\prime} \mathrm{W}$. $50^{\circ} 36 \cdot 4^{\prime}$ N. $\quad 2^{\circ} 56 \cdot 4^{\prime} \mathrm{W}$. $50^{\circ} 30 \cdot 7^{\prime} \mathrm{N} . \quad 2^{\circ} 50 \cdot 7^{\prime} \mathrm{W}$

43
I03

42

42
IO2

$4 \mathrm{I}$

3

2

I

5

Area 9

7
roI
8
9
10
ro0
99
$(28$
$(29$
$(27$
$(33$

$50^{\circ} 36 \cdot 4^{\prime} \mathrm{N} . \quad 2^{\circ} 50 \cdot 2^{\prime} \mathrm{W}$.

$50^{\circ} 30 \cdot 6^{\prime} \mathrm{N} . \quad 2^{\circ} 45 \cdot 35^{\prime} \mathrm{W}$. $50^{\circ} 35^{\prime} 8^{\prime} \mathrm{N} . \quad 2^{\circ} 44^{\prime} 2^{\prime} \mathrm{W}$. $50^{\circ} 30 \cdot 8^{\prime} \mathrm{N} . \quad 2^{\circ} 39^{\circ} \mathrm{I}^{\prime} \mathrm{W}$ $50^{\circ} 34.45^{\prime} \mathrm{N} . \quad 2^{\circ} 38.85^{\prime} \mathrm{W}$. $50^{\circ} 37 \cdot 25^{\prime} \mathrm{N} . \quad 2^{\circ} 25^{\prime} 6^{\prime} \mathrm{W}$ $50^{\circ} 37 \cdot 3^{\prime} \mathrm{N} . \quad 2^{\circ} 25 \cdot 4^{\prime} \mathrm{W}$ $50^{\circ} 37 \cdot \mathrm{I}^{\prime} \mathrm{N} . \quad 2^{\circ} 24^{\circ} 6^{\prime} \mathrm{W}$. $50^{\circ} 36.95^{\prime} \mathrm{N} . \quad 2^{\circ} 22 \cdot 9^{\prime} \mathrm{W}$. $50^{\circ} 37^{\circ} 0^{\prime} \mathrm{N} . \quad 2^{\circ} 20^{\circ} 6^{\prime} \mathrm{W}$.

$50^{\circ} 36 \cdot 4^{\prime} \mathrm{N} . \quad 2^{\circ} 19 \cdot 75^{\prime} \mathrm{W}$. $50^{\circ} 29^{\circ} 6^{\prime} \mathrm{N} . \quad 2^{\circ} 15^{\circ} 5^{\prime} \mathrm{W}$. $50^{\circ} 34^{\prime} 6^{\prime} \mathrm{N} . \quad 2^{\circ} 14.45^{\prime} \mathrm{W}$. $50^{\circ} 33^{\circ} 95^{\prime} \mathrm{N} . \quad 2^{\circ}$ II. $2^{\prime} \mathrm{W}$. $50^{\circ} 34^{\circ} 0^{\prime} \mathrm{N} . \quad 2^{\circ} 08 \cdot 7^{\prime} \mathrm{W}$. $50^{\circ} 30 \cdot 4^{\prime} \mathrm{N} . \quad 2^{\circ} 06 \cdot 4^{\prime} \mathrm{W}$. $50^{\circ} 3 \mathrm{I} \cdot \mathrm{I}^{\prime} \mathrm{N} . \quad \mathrm{I}^{\circ} 57 \cdot 5^{\prime} \mathrm{W}$. $50^{\circ} 37.5^{\prime} \mathrm{N} . \quad \mathrm{I}^{\circ} 55.15^{\prime} \mathrm{W}$. $50^{\circ} 37 \cdot 7^{\prime} \mathrm{N} . \quad \mathrm{I}^{\circ} 54 \cdot 9^{\prime} \mathrm{W}$. $50^{\circ} 39^{\circ} 0^{\prime} \mathrm{N}$. $\mathrm{I}^{\circ} 54^{\circ} 7^{\prime} \mathrm{W}$. $50^{\circ} 37 \cdot 9^{\prime} \mathrm{N} . \quad \mathrm{I}^{\circ} 55^{\circ} 3^{\prime} \mathrm{W}$

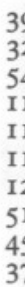

39
32
54
I
I
I
5
45
37

m. + sh.

s.m. + sh

f.s.m.

m.

$\mathrm{m}$.

m.

m.s.

f.m.s.

f.m.s.

f.m.s.

m.s.

c.m.s.

m.s. + sh.

f.m.s.

s.m.

f.m.s.

s.m. + sh.

m.s.

m.s. + sh.

c.m.s.

$\begin{array}{cl}\frac{1}{2} & 2 \cdot 2 \\ \mathrm{~F} & 2 \cdot 2 \\ \mathrm{~F} & 2 \cdot 2(\mathrm{I}) / \mathrm{H} \\ \mathrm{2} & 2 \cdot 2 \\ \mathrm{I} & 2 \cdot 2 \\ \mathrm{I} & 2 \cdot 2 \\ \mathrm{I} & \mathbf{1} \\ \mathrm{F} & 2 \cdot 2(\mathrm{I}) / \mathrm{H} \\ \mathrm{F} & 2 \cdot 2(2) / \mathrm{H} \\ \mathrm{F} & 2 \cdot 2(2) / \mathrm{H} \\ \mathrm{F} & 2 \cdot 2(2) / \mathrm{H}\end{array}$

$\begin{array}{lcl}\text { f.m.s. } & \frac{1}{2} & 2 \cdot 2 \\ \text { c.m.s. } & \mathrm{F} & 2 \cdot 2(\mathrm{I} / \mathrm{IO}) / \mathrm{H} \\ \text { s.+gr. } & \mathrm{I} & 2 \cdot 2 \\ \text { c.s.+gr. } & \mathrm{F} & 2 \cdot 2(\mathrm{I} / \mathrm{IO}) / \mathrm{H} \\ \text { m.s. +gr. } & \mathrm{F} & \mathrm{H} \\ \text { m.gr. } & 3-4 & 5(2) / \mathrm{H} \\ \text { m.gr. } & \frac{1}{2} \mathrm{~F} & 5(2) / \mathrm{H} \\ \text { m. } & \mathrm{I} & 2 \cdot 2 \\ \text { m.s. } & \text { II. } 2 ; 2 & 2 \cdot 2 \\ \text { m.gr. } & \mathrm{F} & \mathrm{H}\end{array}$

$\begin{array}{lcl}\text { m.gr. } & 3 & 5(2) / \mathrm{H} \\ \text { st. } & \frac{3}{4} \mathrm{~F}^{(\mathrm{T})} & \mathrm{H} \\ \text { gr. + st. } & 2 & \mathrm{H} \\ \text { sh.gr. + st. } & 2-3 & \mathrm{H} \\ \text { sh.gr. } & 2 & \mathrm{H} \\ \text { st. + gr. } & \frac{3}{4} \mathrm{~F}(\mathrm{~T}) & \mathrm{H} \\ \text { st. + c.s. } & \mathrm{F}(\mathrm{T}) & \mathrm{H} \\ \text { cln.sh.gr. } & \mathrm{F} & \mathrm{H}) \\ \text { m.gr. } & \mathrm{F} & \mathrm{H}) \\ \text { f.gr. +m. } & \mathrm{F} & \mathrm{H}) \\ \text { cln.s. } & \mathrm{I} / 3 \mathrm{~F} & \mathrm{H})\end{array}$

2.2(I)/H 5(I) $/ \mathrm{H}$ $2 \cdot 2$ (I) $/ \mathrm{H}$ $2 \cdot 2(2) / \mathrm{H}$

$2 \cdot 2$

$2 \cdot 2$ $2 \cdot 2(\mathrm{I}) / \mathrm{H}$ 


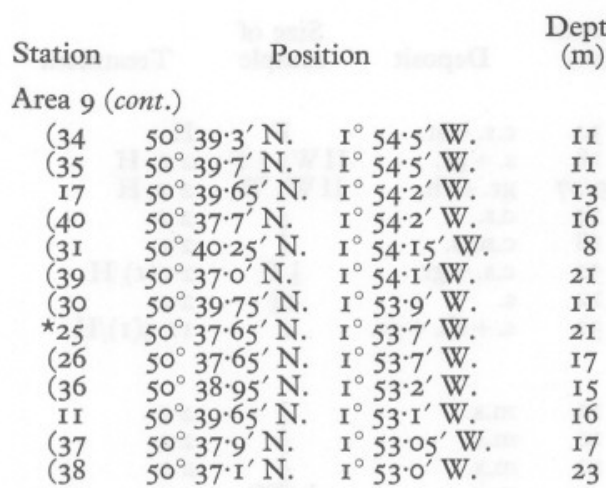

Area 10

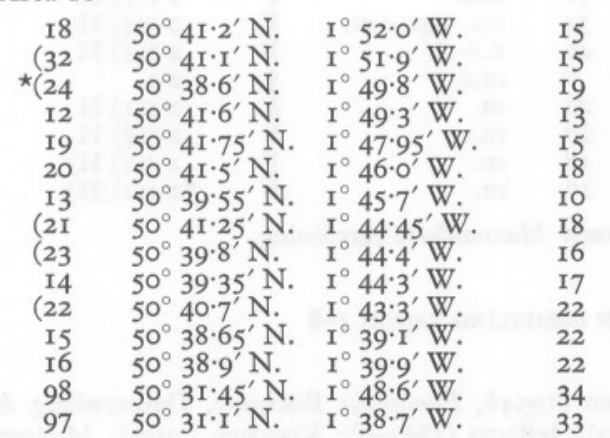

Area II

$\begin{array}{llll}96 & 50^{\circ} 29 \cdot 3^{\prime} \mathrm{N} . & \mathrm{I}^{\circ} 29^{\prime} 4^{\prime} \mathrm{W} . & 33 \\ 95 & 50^{\circ} 28 \cdot 7^{\prime} \mathrm{N} . & \mathrm{I}^{\circ} \mathrm{I}^{\prime} \cdot 7^{\prime} \mathrm{W} . & 32 \\ 94 & 50^{\circ} 30 \cdot \mathrm{I}^{\prime} \mathrm{N} . & \mathrm{I}^{\circ} 09^{\prime} \mathbf{2}^{\prime} \mathrm{W} . & 33 \\ 93 & 50^{\circ} 30 \cdot 7^{\prime} \mathrm{N} . & 0^{\circ} 59^{\prime} \mathrm{W} . & 27 \\ 92 & 50^{\circ} 32 \cdot \mathrm{I}^{\prime} \mathrm{N} . & 0^{\circ} 5 \mathrm{I}^{\prime} \mathrm{I}^{\prime} \mathrm{W} . & 22 \\ 54 & 50^{\circ} 39 \cdot 4^{\prime} \mathrm{N} . & 0^{\circ} 46^{\prime} 9^{\prime} \mathrm{W} . & \mathrm{I} \\ 55 & 50^{\circ} 36 \cdot 5^{\prime} \mathrm{N} . & 0^{\circ} 38 \cdot 6^{\prime} \mathrm{W} . & 30 \\ 9 \mathrm{I} & 50^{\circ} 34 \cdot 7^{\prime} \mathrm{N} . & 0^{\circ} 35^{\circ} \cdot 7^{\prime} \mathrm{W} . & 49 \\ 56 & 50^{\circ} 37 \cdot 2^{\prime} \mathrm{N} . & 0^{\circ} 35 \cdot 5^{\prime} \mathrm{W} . & 32 \\ 57 & 50^{\circ} 38 \cdot 4^{\prime} \mathrm{N} . & 0^{\circ} 29^{\prime} \mathrm{W} . & 25 \\ 90 & 50^{\circ} 36 \cdot 6^{\prime} \mathrm{N} . & 0^{\circ} 26 \cdot 4^{\prime} \mathrm{W} . & 37\end{array}$

Area 12

\begin{tabular}{|c|c|c|c|}
\hline 58 & $50^{\circ} 4 \mathrm{I} \cdot 2^{\prime} \mathrm{N}$. & $0^{\circ} 24 \cdot 6^{\prime} \mathrm{W}$. & 20 \\
\hline 59 & $50^{\circ} 42 \cdot 4^{\prime} \mathrm{N}$. & $0^{\circ} 18 \cdot 6^{\prime} \mathrm{W}$. & I9 \\
\hline 89 & $50^{\circ} 36.8^{\prime} \mathrm{N}$. & $0^{\circ} \mathrm{I} 6.9^{\prime} \mathrm{W}$. & 54 \\
\hline 60 & $50^{\circ} 440^{\prime} \mathrm{N}$. & $0^{\circ} 13.0^{\prime} \mathrm{W}$. & I8 \\
\hline 88 & $50^{\circ} 37^{\circ} 7^{\prime} \mathrm{N}$ & $0^{\circ} 07 \cdot 7^{\prime} \mathrm{W}$. & 45 \\
\hline $6 r$ & $50^{\circ} 44^{\prime} 7^{\prime} \mathrm{N}$. & $0^{\circ} 06.5^{\prime} \mathrm{W}$. & 19 \\
\hline 62 & $50^{\circ} 45^{\prime} 3^{\prime} \mathrm{N}$. & $0^{\circ} 00 \cdot 6^{\prime} \mathrm{W}$. & 19 \\
\hline & $50^{\circ} 37^{\circ} 9^{\prime} \mathrm{N}$ & $\mathrm{O}^{\circ} \mathrm{OI} \cdot 7^{\prime} \mathrm{E}$ & 49 \\
\hline & $50^{\circ} 44^{\prime} 4^{\prime} \mathrm{N}$ & $0^{\circ} 06 \cdot 0^{\prime} \mathrm{E}$. & 21 \\
\hline & $50^{\circ} 38 \cdot 8^{\prime} \mathrm{N}$. & $0^{\circ} \mathrm{II} \cdot \mathrm{I}^{\prime} \mathrm{E}$. & \\
\hline
\end{tabular}

Size of Deposit sample

Treatment

$\begin{array}{lcl}\text { cln.s. } & ? & \mathrm{H}) \\ \text { gr. +s. } & ? & \mathrm{H}) \\ \text { m.gr. } & 3-4 & 5(\mathrm{I}) / \mathrm{H} \\ \text { f.m.gr. } & \mathrm{F} & \mathrm{H}) \\ \text { m. + st. } & ? & \mathrm{H}) \\ \text { s. + gr. +st. } & ? & \mathrm{H}) \\ \text { m. +gr. +st. } & ? & \mathrm{H}) \\ \text { m.gr. } & \mathrm{F} & \mathrm{H} \\ \text { m.gr. } & \mathrm{F} & \mathrm{H}) \\ \text { m.s. +gr. } & ? & \mathrm{H}) \\ \text { m. } & 2-3 & 5(2) / \mathrm{H} \\ \text { s. }+ \text { gr. } & \frac{1}{2} \mathrm{~F} & \mathrm{H}) \\ \text { s.gr. }+ \text { st. } & \mathrm{F} & \mathrm{H})\end{array}$

$\begin{array}{lll}\text { m. } & \text { F } & 2 \cdot 2(2) / \mathrm{H} \\ \text { black m. } & \text { F } & 2 \cdot 2(2) / H\end{array}$

st. $\mathrm{T} \quad \mathrm{H}$ )

black $m$. II : $\frac{1}{4} ; \frac{1}{4} \quad 2 \cdot 2$

silty s. II: $\mathrm{I}$; I/8 $2 \cdot 2$

W All

m.gr. F $5\left(\frac{1}{2}\right) /$ Rest lost)

? r. $\begin{array}{lll}\text { cln.s. } & \overline{\mathrm{W}} \quad \overline{\text { All }}\end{array}$

m. + st. II: $3-4 / 3-4$ 5(2)/H)

gr. + st.

m. gr.

gr. + st. + c.s.

gr. + st. + c.s.

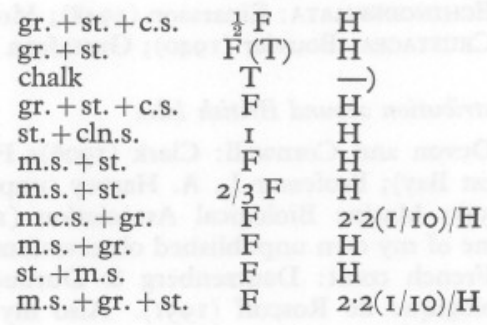

m.s. + st.

m.s. + st.

s. + sh.gr.

cln.s. + sh.

sh. + st.

cln.s. + sh.

m.s.

st. + little s.

m.s.

st.

$\begin{array}{cl}\frac{1}{2} \mathrm{~F} & \mathrm{H} \\ \frac{1}{4} \mathrm{~F} & \mathrm{H} \\ \mathrm{F} & 2 \cdot 2(\mathrm{I} / \mathrm{IO}) / \mathrm{H} \\ \mathrm{I} & \frac{1}{2} \\ \mathrm{I} / 3 & \mathrm{H} \\ \mathrm{F} & 2 \cdot 2(\mathrm{I}) / \mathrm{H} \\ 2 & 2 \cdot 2(\mathrm{I}) / \mathrm{H} \\ ? \mathrm{~T} & \mathrm{H} \\ 2 & 2 \cdot 2(\mathrm{I}) / \mathrm{H} \\ \mathrm{T} & \mathrm{H}\end{array}$

Area 13
$64 \quad 50^{\circ} 43 \cdot 7^{\prime}$ N. $\quad 0^{\circ}$ II $\cdot 5^{\prime}$ E.
2 I m. + st.
$\underset{\mathrm{F}}{\mathrm{H}}$
* Conventional fine-mesh dredge. 


\begin{tabular}{|c|c|c|c|c|c|c|}
\hline \multicolumn{3}{|c|}{ Station } & \multirow[t]{2}{*}{$\begin{array}{c}\text { Depth } \\
\text { (m) }\end{array}$} & \multirow{2}{*}{\multicolumn{3}{|c|}{$\begin{array}{l}\text { Size of } \\
\text { sample }\end{array}$}} \\
\hline \multicolumn{3}{|c|}{ Area $I_{3}$ (cont.) } & & & & \\
\hline & $50^{\circ} 40 \cdot 5^{\prime} \mathrm{N}$. & $0^{\circ} 29 \cdot 9^{\prime} \mathrm{E}$. & 34 & c.s. + st. & F & $\mathrm{H}$ \\
\hline 65 & $50^{\circ} 44^{\circ} 6^{\prime} \mathrm{N}$. & $0^{\circ} 3 \mathrm{I} \cdot 9^{\prime} \mathrm{E}$. & 18 & s. + gr. & IIW; $\frac{1}{4} \mathrm{~F}$ & $2 \cdot 2, \mathrm{H}$ \\
\hline 74 & $50^{\circ} 45^{\circ} \mathrm{I}^{\prime} \mathrm{N}$. & $0^{\circ} 37 \cdot 4^{\prime} \mathrm{E}$. & $29 / 27$ & gr. + sh. & II W; W & $2 \cdot 2, \mathrm{H}$ \\
\hline 72 & $50^{\circ} 47 \cdot 6^{\prime} \mathrm{N}$. & $0^{\circ} 39 \cdot 7^{\prime} \mathrm{E}$. & I4 & c.s. & $\frac{3}{4}$ & $2 \cdot 2$ \\
\hline 73 & $50^{\circ} 46 \cdot 7^{\prime} \mathrm{N}$. & $0^{\circ} 37 \cdot 8^{\prime} \mathrm{E}$. & 18 & c.m.s. & $\frac{3}{4}$ & $2 \cdot 2$ \\
\hline 83 & $50^{\circ} 4 \mathrm{I} \cdot 5^{\prime} \mathrm{N}$. & $0^{\circ} 39^{\prime} 6^{\prime} \mathrm{E}$. & 52 & c.s. + gr. & $\frac{1}{2} \mathrm{~F}$ & $2 \cdot 2(\mathrm{I}) / \mathrm{H}$ \\
\hline $7 I$ & $50^{\circ} 48 \cdot 8^{\prime} \mathrm{N}$. & $0^{\circ} 4 \mathrm{I} \cdot 5^{\prime} \mathrm{E}$. & 12 & s. & $I_{4}^{3}$ & $2 \cdot 2$ \\
\hline 75 & $50^{\circ} 47 \cdot \mathrm{I}^{\prime} \mathrm{N}$ & $0^{\circ} 43 \cdot 7^{\prime} \mathrm{E}$. & $3 I$ & s. + sh. + gr. & 2 & II $\cdot 5(\mathrm{I}) / \mathrm{H}$ \\
\hline \multicolumn{7}{|l|}{ Area 14} \\
\hline 70 & $50^{\circ} 50 \cdot \mathrm{I}^{\prime} \mathrm{N}$. & $0^{\circ} 43 \cdot 2^{\prime} \mathrm{E}$. & I0 & m.s. & $\frac{1}{2}$ & $2 \cdot 2$ \\
\hline 69 & $50^{\circ} 5 \mathrm{I} \cdot 3^{\prime} \mathrm{N}$. & $0^{\circ} 45^{\circ} 0^{\prime} \mathrm{E}$. & IO & m.s. & $\frac{1}{2}$ & $2 \cdot 2$ \\
\hline 68 & $50^{\circ} 52 \cdot 4^{\prime} \mathrm{N}$. & $0^{\circ} 46 \cdot 6^{\prime} \mathrm{E}$. & I0 & m.s. & $\frac{2}{1}$ & $2 \cdot 2$ \\
\hline 67 & $50^{\circ} 53.3^{\prime} \mathrm{N}$. & $0^{\circ} 48 \cdot 3^{\prime} \mathrm{E}$. & 9 & m.s. & $\frac{1}{2}(\mathrm{~W})$ & $2 \cdot 2$ \\
\hline 76 & $50^{\circ} 49^{\circ} 8^{\prime} \mathrm{N}$. & $0^{\circ} 48 \cdot 6^{\prime} \mathrm{E}$. & $3 I$ & m.s. & $\mathrm{F}$ & $2 \cdot 2(\mathrm{I}) / \mathrm{H}$ \\
\hline $8 I$ & $50^{\circ} 46 \cdot \mathrm{I}^{\prime} \mathrm{N}$. & $0^{\circ} 49 \cdot 2^{\prime} \mathrm{E}$. & 34 & c.s. + gr. + st. & $\mathrm{F}$ & $2 \cdot 2\left(\frac{1}{4}\right) / \mathrm{H}$ \\
\hline 82 & $50^{\circ} 4 \mathrm{I} \cdot 7^{\prime} \mathrm{N}$. & $0^{\circ} 49 \cdot 4^{\prime} \mathrm{E}$. & 40 & s. + st. & $\mathrm{F}$ & $2 \cdot 2(\mathrm{I}) / \mathrm{H}$ \\
\hline 66 & $50^{\circ} 54^{\prime} 4^{\prime} \mathrm{N}$. & $0^{\circ} 50 \cdot \mathrm{I}^{\prime} \mathrm{E}$. & 8 & m.s. & $\frac{3}{4}$ & $2 \cdot 2$ \\
\hline 77 & $50^{\circ} 52 \cdot 2^{\prime} \mathrm{N}$. & $0^{\circ} 53 \cdot 2^{\prime} \mathrm{E}$. & 27 & m. & $\mathrm{F}$ & $2.5(\mathrm{I}) / \mathrm{H}$ \\
\hline 78 & $50^{\circ} 57 \cdot 6^{\prime} \mathrm{N}$. & $\mathrm{I}^{\circ} 02 \cdot 4^{\prime} \mathrm{E}$. & 27 & m.s. & F & $2 \cdot 5\left(\frac{3}{4}\right) / \mathrm{H}$ \\
\hline (79 & $51^{\circ} 00 \cdot 2^{\prime} \mathrm{N}$. & $\mathrm{I}^{\circ} \mathrm{O} 4 \cdot 2^{\prime} \mathrm{E}$. & 18 & m. & $\mathrm{F}$ & $2 \cdot 2(\mathrm{I}) / \mathrm{H})$ \\
\hline$(80$ & $5 \mathrm{I}^{\circ} 02 \cdot 6^{\prime} \mathrm{N}$. & $\mathrm{I}^{\circ} 06^{\prime} 6^{\prime} \mathrm{E}$. & 17 & $\mathrm{~m}$. & $\mathrm{F}$ & $\left.\star_{2} \cdot 2(\mathrm{I}) / \mathrm{H}\right)$ \\
\hline
\end{tabular}

* Part of sample lost, only Maxmulleria remaining.

REFERENCES USED IN COMPILING TABLES I-8

\section{Geographical distribution}

MollusCa: Allen (I954a, Nucula); Allen (1954b, Pandora); Bucquoy, Dautzenberg \& Dollfus (r882-98); Forbes \& Hanley (1853); Jeffreys (r862-9); Knudsen (r949); Madsen (I949); Thorson (I94I).

ECHINODERMATA: Einarsson (1948); Mortensen (1927).

CRUSTACEA: Bouvier (I940); Gustafson (1934).

\section{Distribution around British Isles}

Devon and Cornwall: Clark (1906); Ford (1923, and unpublished records from Great West Bay); Professor L. A. Harvey (unpublished fauna list of Scilly Isles); Holme (I950, I953); Marine Biological Association (I957); Todd (I903, I906); Vevers (I952). Also some of my own unpublished observations.

French coast: Dautzenberg \& Durouchoux (1913-14); Prenant (1932, 1939); Station Biologique de Roscoff (I95I). Also my own unpublished observations on the Brittany coasts.

Ireland: Nichols (I900).

Isle of Man: Jones (1956); Moore (I937).

Clyde: Knight (I90I); Scottish Marine Biological Association (I96I); Todd (I90I).

Orkney: Rendall (1956).

North Sea: Birkett (unpublished); Birkett (I953); Davis (1923, 1925); Hagmeier (1925); McIntyre (I958); Stephen (1933, 1934); Ursin (I952, I960).

\section{Feeding Habits}

Allen (1958a, Lucinacea); Allen (1958b, Cochlodesma); Hunt (1925); MacGinitie (1949, Callianassa and Upogebia); Morton (1959, Dentalium); Roushdy and Hansen (1960, Ophiocomina); Yonge (1946, Turritella). 
Ford (1923)

RE-IDENTIFICATION OF SPISULA ELLIPTICA

Grab station 35. Five pairs, labelled S. elliptica. Rather small shells which appeared to be S. elliptica, but which might be $S$. solida.

Grab station 47. Five pairs, labelled $S$. elliptica. Re-identified as S. solida.

Conical dredge, 24 August. Two pairs, labelled $S$. elliptica. Re-identified as $S$. solida.

Originally determined by $\mathrm{R}$. Winckworth.

\section{Atkins (1937)}

Shells kindly shown me by the late Dr D. Atkins which were used for her work on ciliary mechanisms. Locality: Plymouth area. Labelled S. elliptica and determined by R. Winckworth. These were re-identified as $S$. solida (3 pairs), $S$. elliptica (2 valves, not a pair). This explains the differences in ciliation found in two specimens by Dr Atkins. Other specimens collected at the same time were mostly $S$. solida, and a few S. elliptica. 